\title{
دلالة اللون في نهج البلاغة _اللون الأبيض والأسود أنموذجاً__
}

م • م سلمان محمد عبد السيد

\section{مديرية تربية واسط}

ملضص البحث: إن حضور الألوان في نهج البلاغة ليس أمراً اعتباطيا؛ لأن اللون بمتلك شفرة

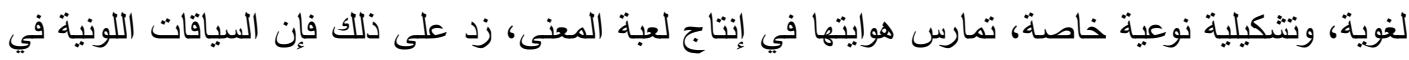

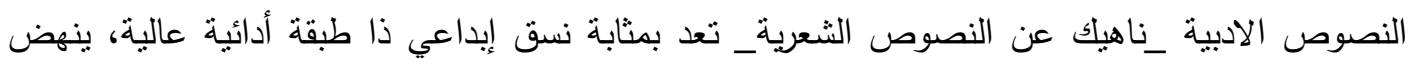

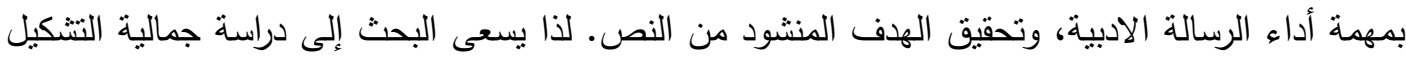

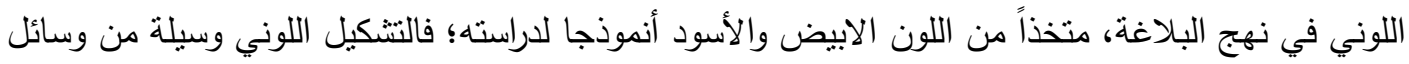

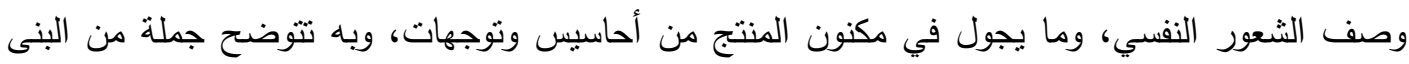

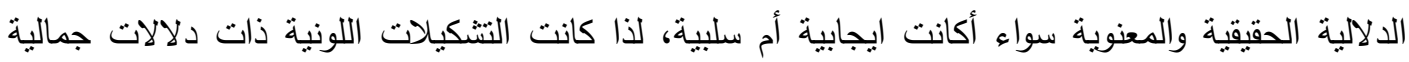
جديرة بالبحث، والتتقيب؛ خصوصاً اذا ما كان ذلك التتقيب في واحة عظيمة من واحات لغة النهات النون (')، وأعني

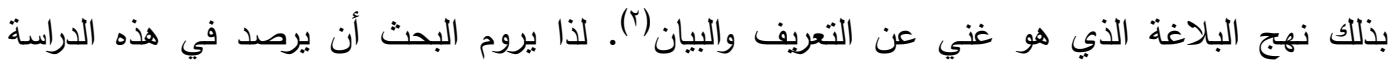

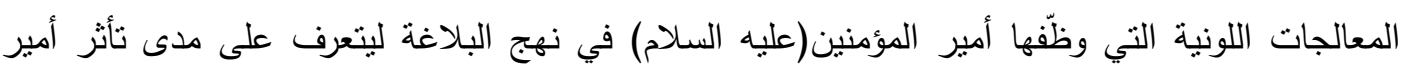
المؤمنين (عليه السلام) بالألوان.

ولابد من الاشارة هنا الى أن هذه الدراسة قد نتاولت الجانب الاستعمالي الصريح والمباشر لألفاظ

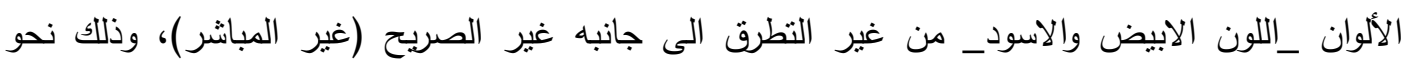

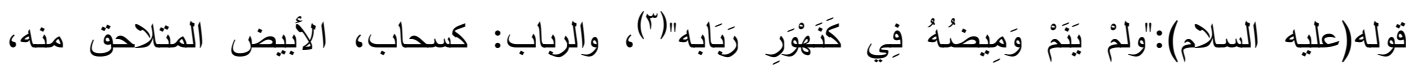

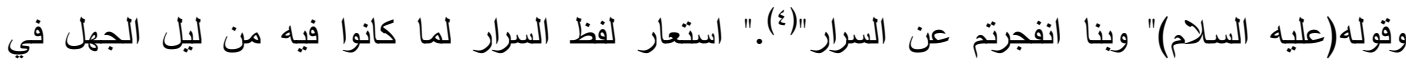

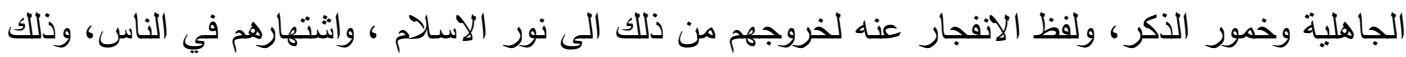

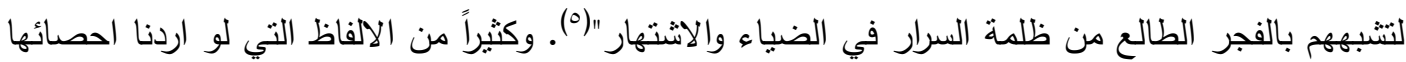
لطال بنا المقام ولضاقت بنا الاوراق. 


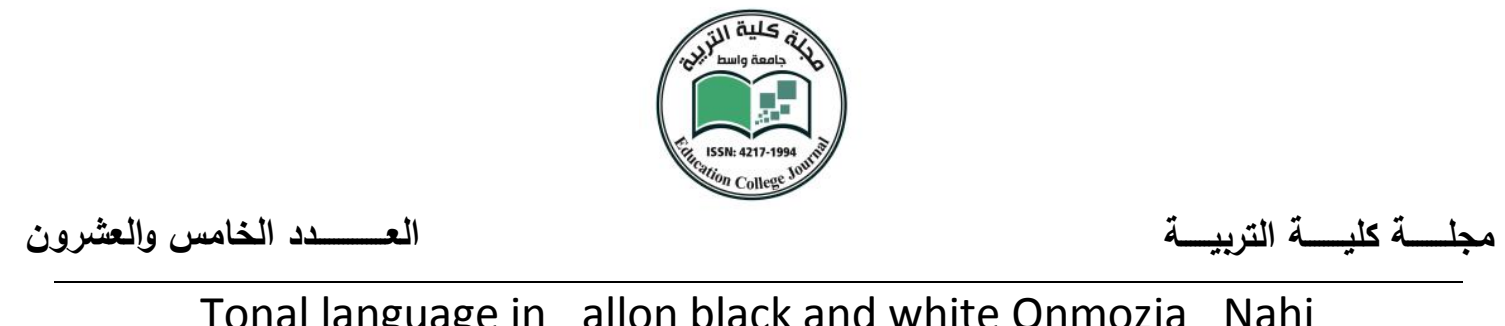

\section{Salman Mohammed Abdel Sayed \\ Educational, Wasit Directorate \\ Wasit province}

\section{Research Summary:}

-The presence of colors in the Nahj is not arbitrary; because the color has a code language, and plastic special quality, practiced hobby in the production of game sense, moreover, the contexts of color in literary texts _nahik for Alcharih_texts serves as a creative format a performance today layer high, get up the task of literary message performance, and achieve the desired goal of the text. So research seeks to aesthetic composition chromatography study in Nahj, taking the white and black color model to study it; Valcecchel chromatography and means of description of psychological feeling, and touring in the innermost product of feelings and attitudes, and has clarified a number of real and moral structures Remember, whether positive or negative, so it was the color combinations of semantics aesthetic worthy of research and exploration; especially if it was excavated in the great oasis of oases Noon language (), and by that I mean rhetoric, who is rich from the definition and the statement approach. So research purports to be monitored in the study of color processors employed by the faithful (peace be upon him) in Nahj to recognize the vulnerability of the faithful (peace be upon him) in color.

It must be noted here that this study has addressed Alastamala frank and direct words colors _allon White Alasud_side is touched by his side is explicit (indirect), so some saying (peace be upon him): "did betrays A-scan in Knhor Robabeh", and psaltery: Kzhab, White successive him, and saying (peace be upon him) "and us Anfjrtm for Aserar." "borrowed word Aserar of what they were in the night of ignorance in ignorance and wines above, blast him and the word of their exit from it to the light of Islam, and Achthaarham in people, so as to Chbham dawn horoscope of darkness Aserar in photophobia and Acnhar. " And many of the terms that if we want to be counted for us primarily long and narrowed our securities. 
الكلمات الافتتاحية : اللغة، اللون ، نهج البلاغة ، الابيض ، الاسود .

المقدمة: اللون من أهم وأجمل ظواهر الطبيعة، ومن أهمّ العناصر الني تشكل الصورة الأدبية لِما

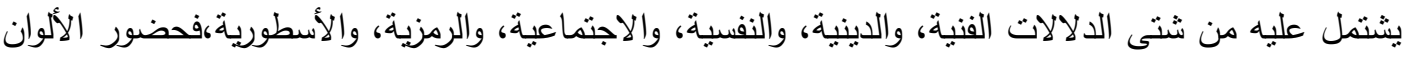

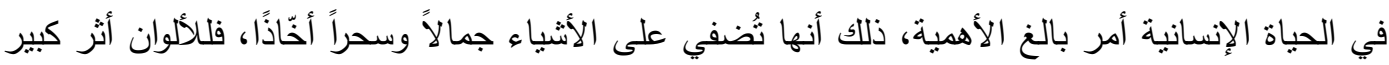

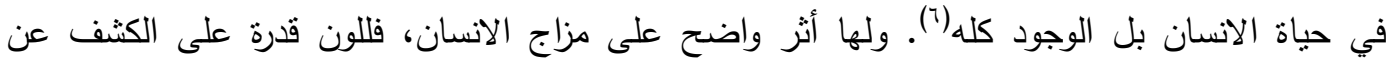

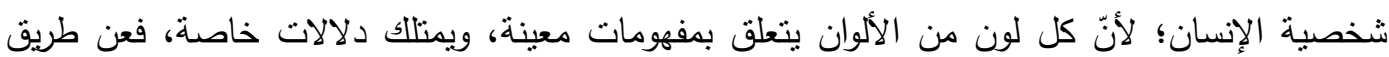

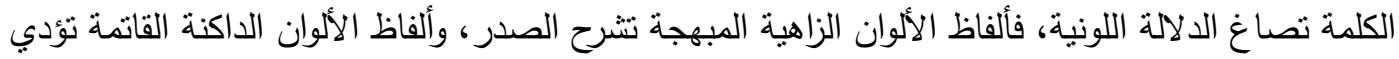

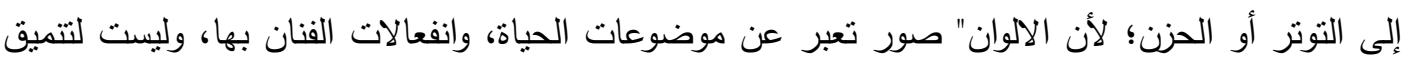

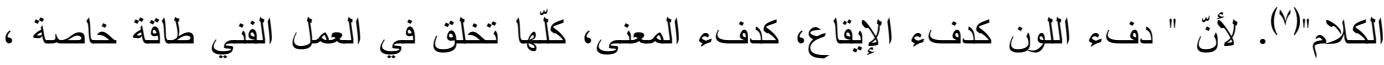
وتؤسس صورة جديدة وجميلة، وتكون لها طاقة مميزة، وتؤسس صورة جديدة، ذات مدلولات متغيرة، تصبها

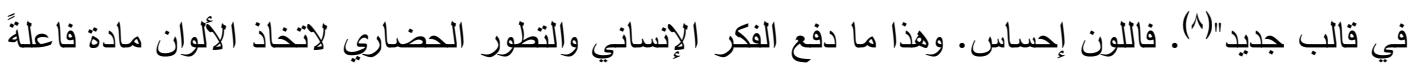

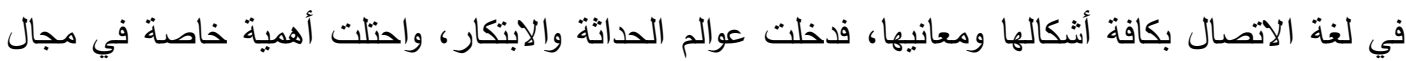

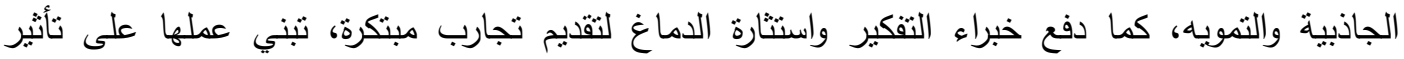
الالوان، لهذا لا يُككنا إنكار الأهمية الكبيرة التي تحتلّها الألوان في قراراتتا اليومية وحالتنا النفسية، يقول

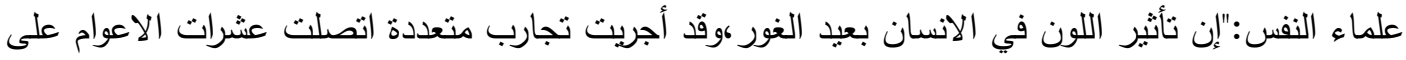

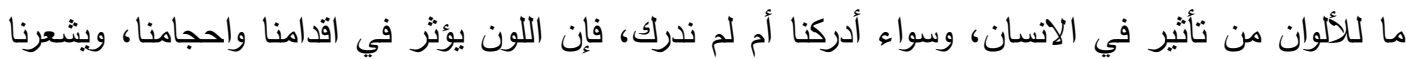

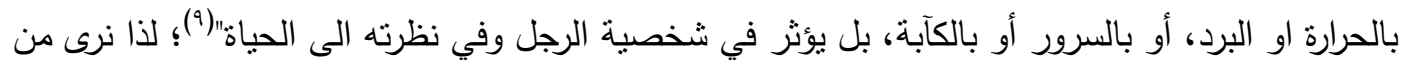

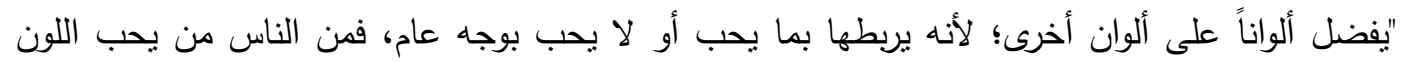

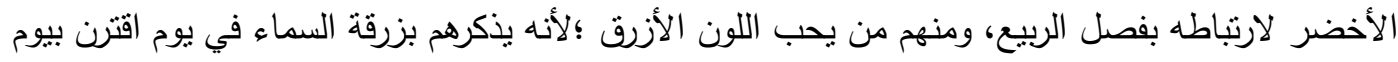

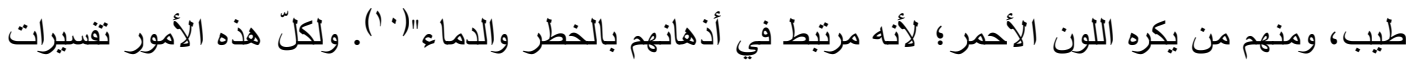

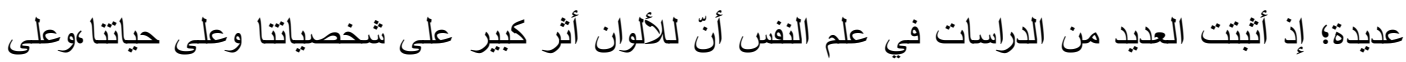

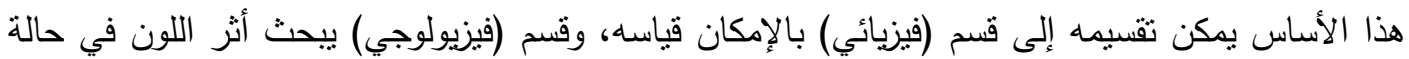

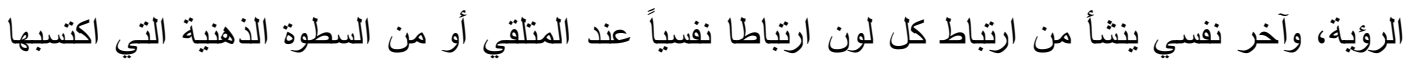

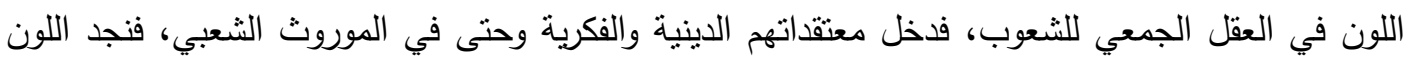

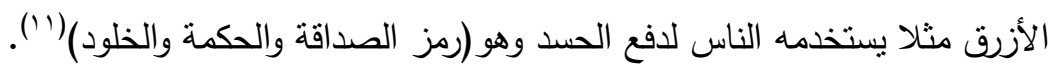


أما أثر الالوان في الموروث العربي فقد عنيث العربية عناية فائقة بالألوان، وذلك على ألسنة شعرائها وخطبائها فيما وصل الينا من رواة أخبارها في العصر الجاهلي، ثم اشتنت هذه العناية في عصور

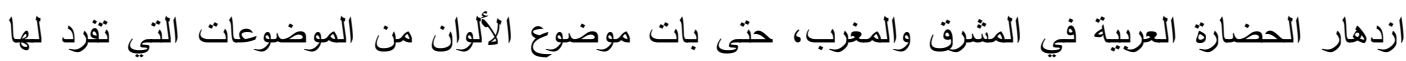

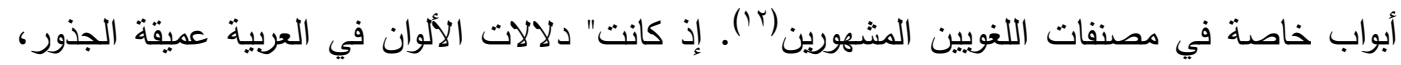
تواكب الحياة العربية في بيئتها المختلفة وتساير منطلباتها الحضارية عبر تاريخها الطويل، إذ تمثل الألوان

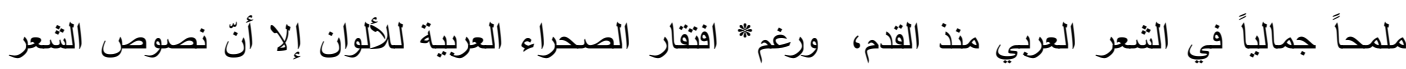

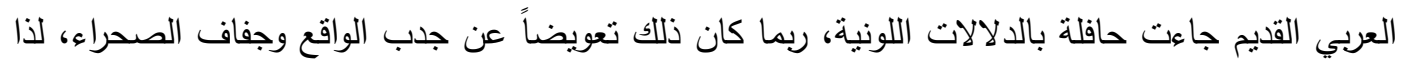

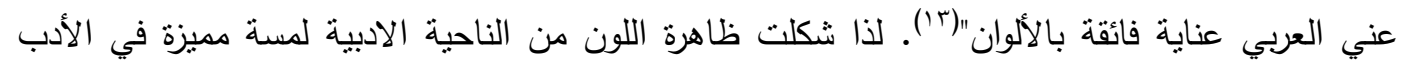

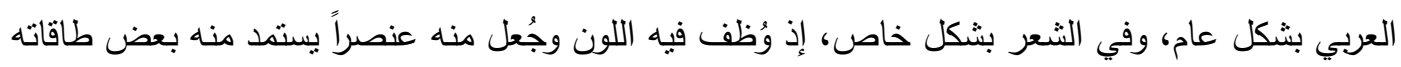

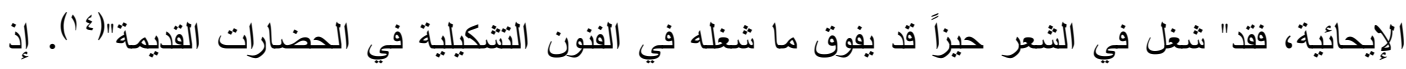

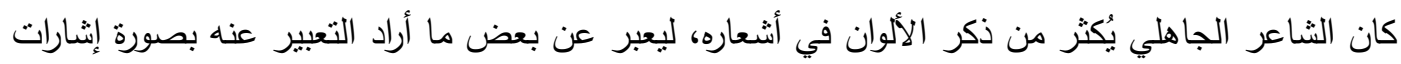

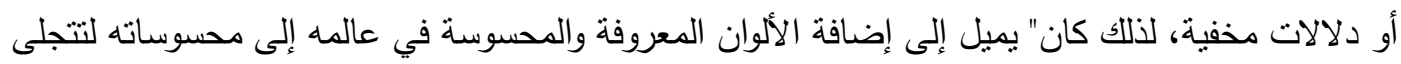

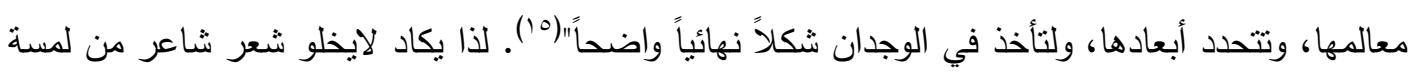
دلالية إثر استعماله لمفردة من المفردات اللونية، وهو دليل على امتلاكهم القدرة الكبيرة في أماكن استعمالها،

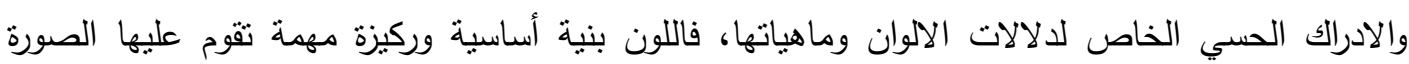

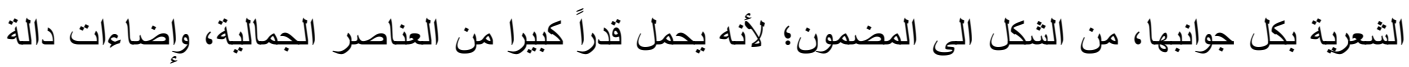

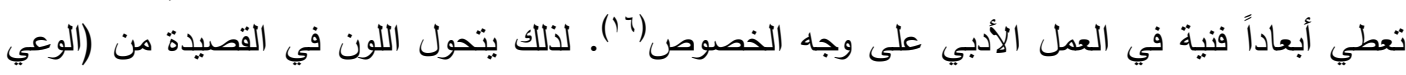

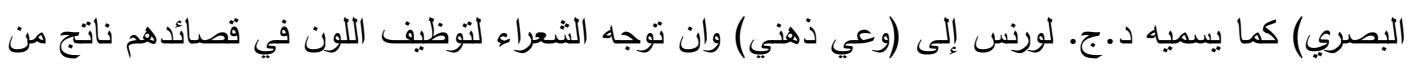

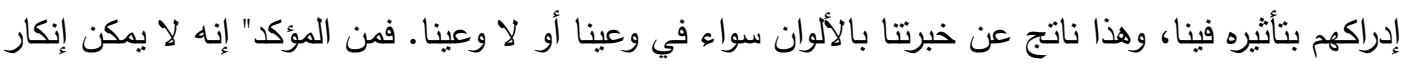

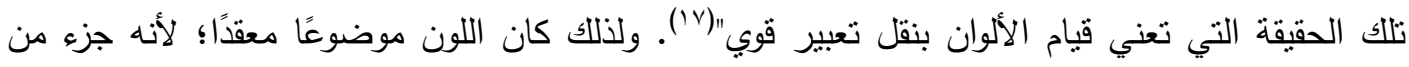

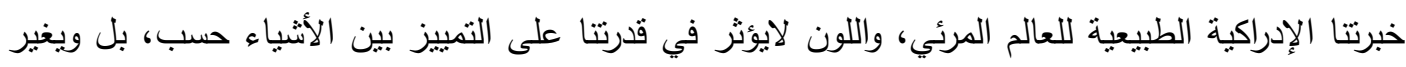

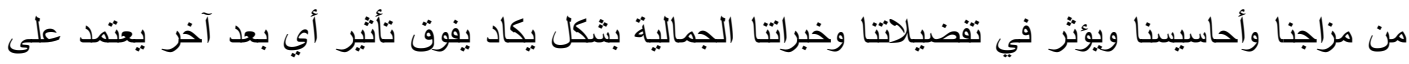

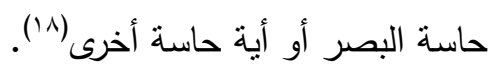

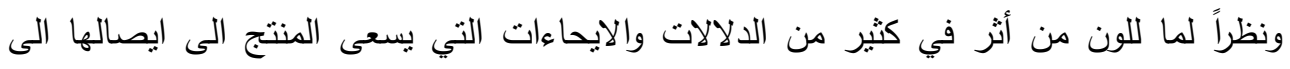

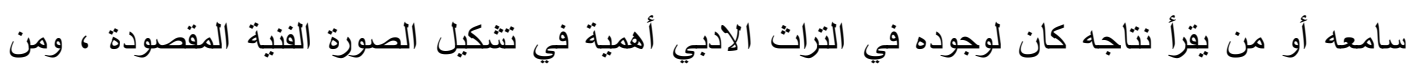


خلال استقرائنا لنهج البلاغة وجدنا للون ودلالته شأنًا بيتحق الوقوف عنده ، وسأكتفي في هذا البحث باللون

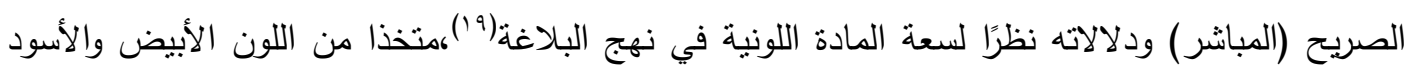

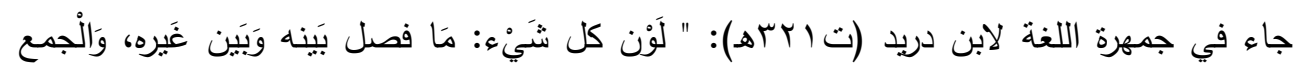

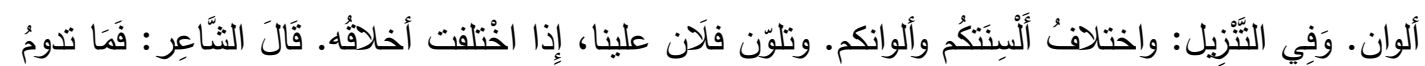

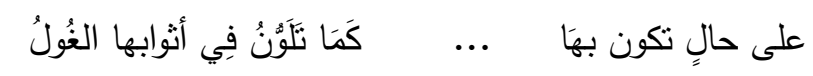

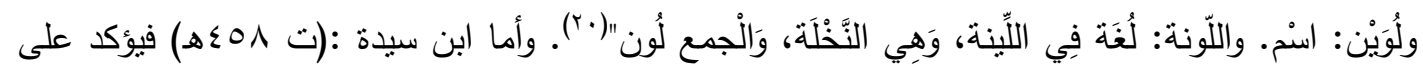

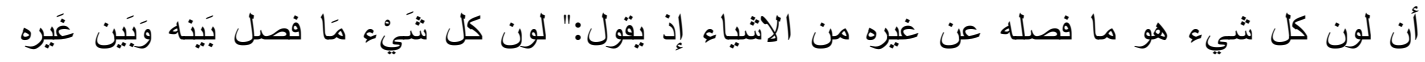

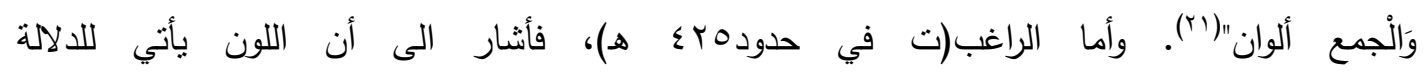

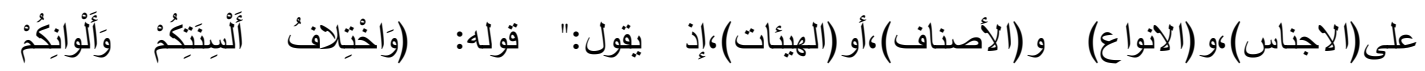

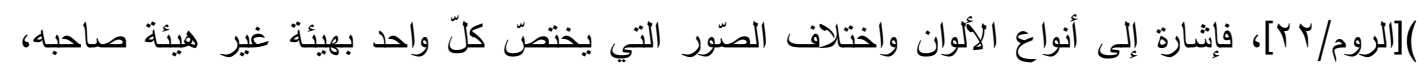

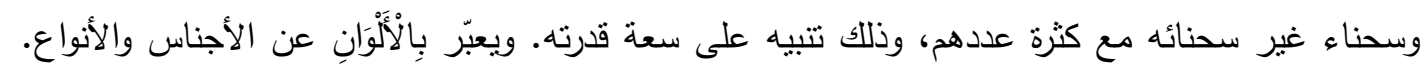

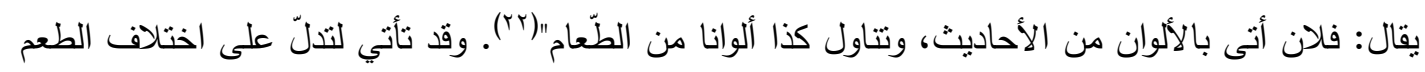

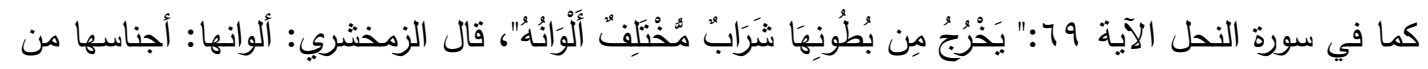

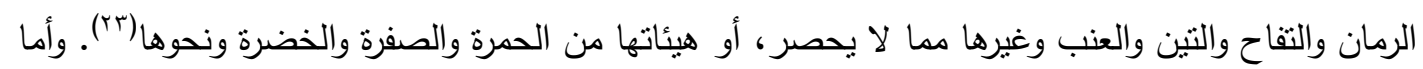

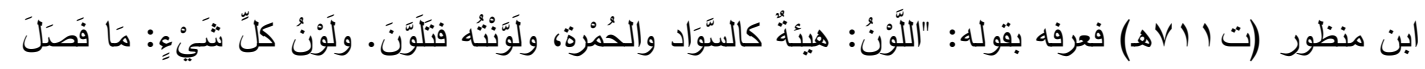

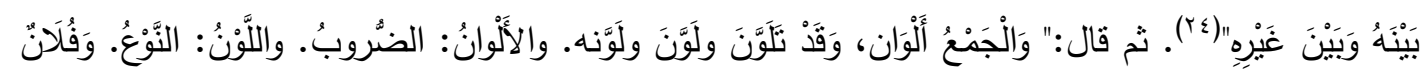

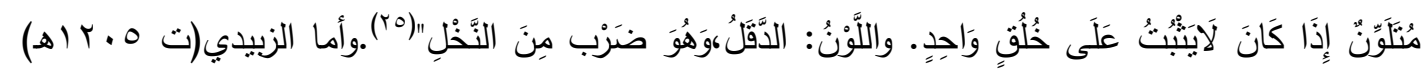

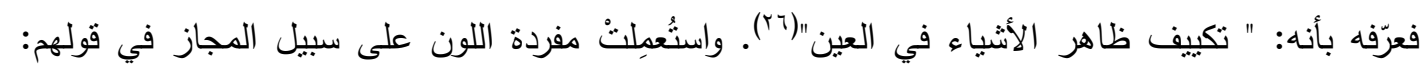

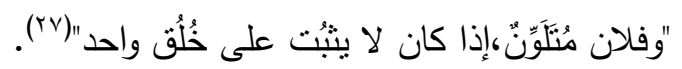


يتحصل مما تقدم أن مفردة اللون في الاستعمال العربي اللغوي جاءت لعدة معانٍ منها:

ا . لون كل شيء هو ما فصله عن غيره من الاشياء.

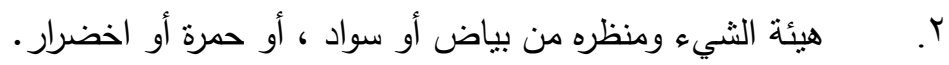

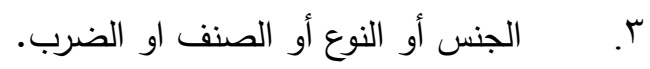

ـ. التغيير والتبدل في أخلاق الإنسان، وعدم ثبات الانسان على خلق واحد.

\section{اللون في الاصطلاح:}

اللون"هو الكيفية الددركة بالبصر من حمرة، وصفرة ،وغيرها"(^(r).هكذا ورد اللون في بعض معاجمنا

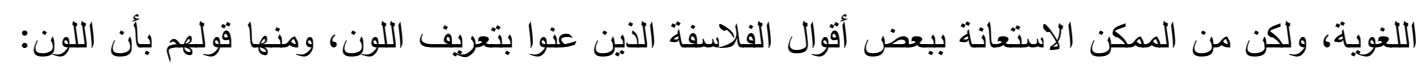

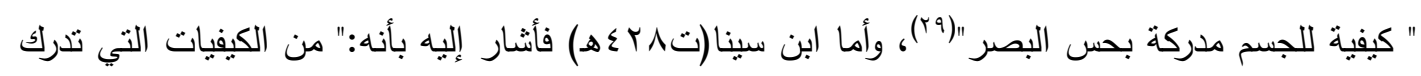

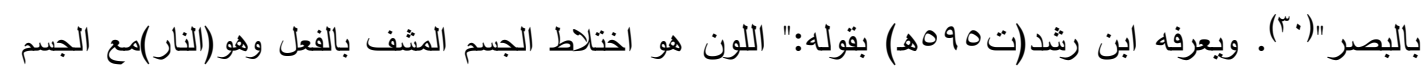

$$
\text { الذي لايمكن فيه أن يستتف وهو الأرض"(r(r). }
$$

وأما في العلوم الحديثة فهو: "خاصية ضوئية تعتمد على طول الموجة،ويتوقف اللون الظاهري

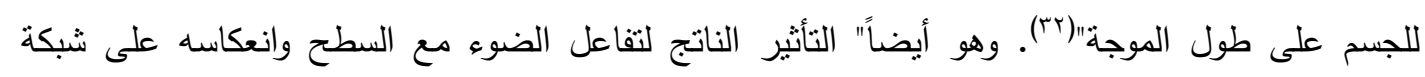

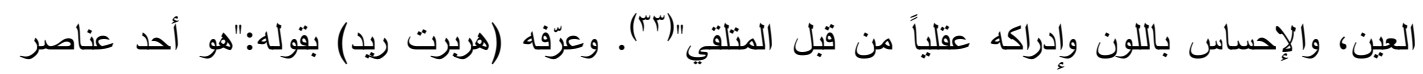

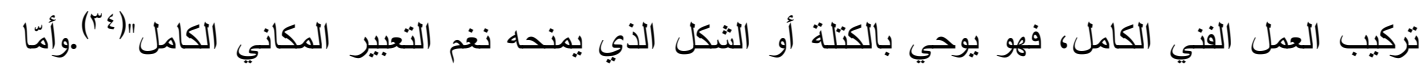

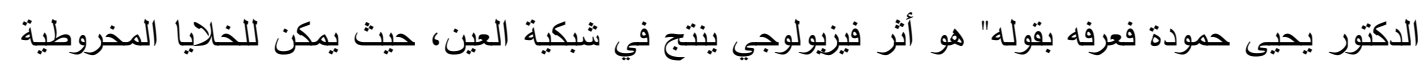

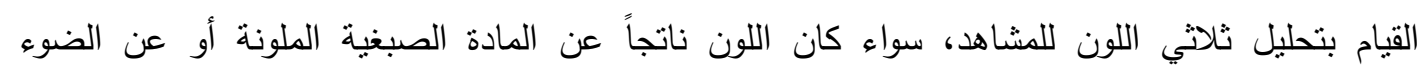

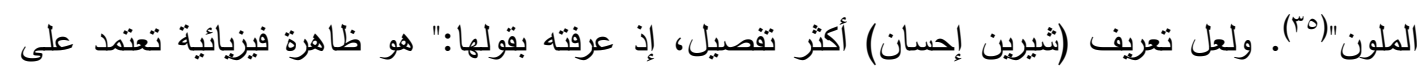

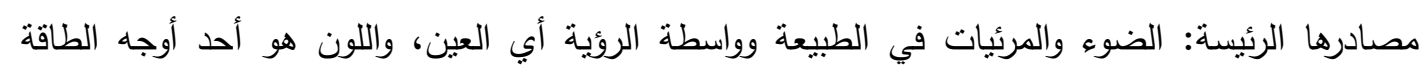

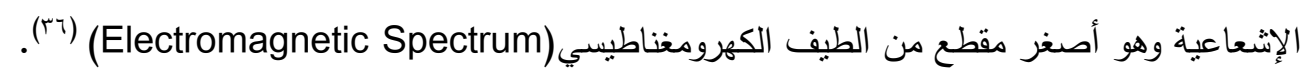

فالضوء ركيزة أساسية في تكوين اللون فهو خبرة بصرية نتاج لعملية الإدراك الحسي، إذ يولد في

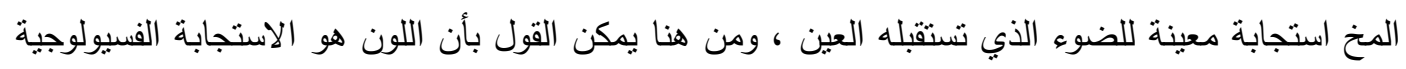


والسيكولوجية للضوء(rV) إذن لا يمكن إنكار أن اللون هو إحساس غير موجود إلا في الدماغ ،أو الجهاز

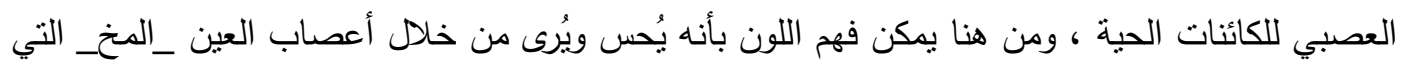

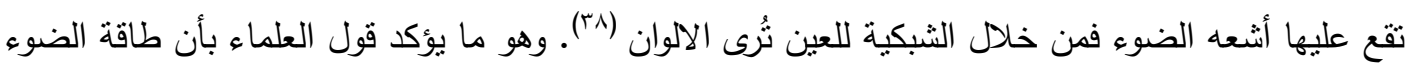

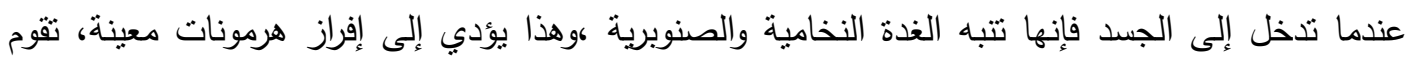
بإحداث مجموعة من العمليات الفسيولوجية، وهذا يشرح لماذا الألوان لها تللك السيطرة المباشرة على أفكارنا

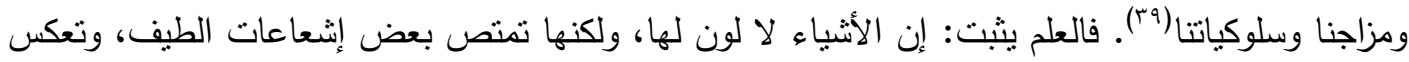

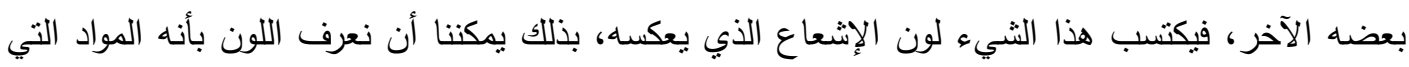

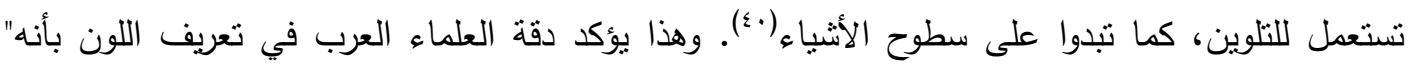

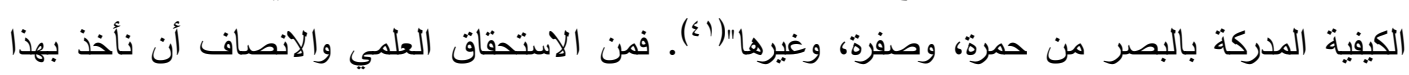
التعريف لما يحمله من أسبقية زمنية ودقة علمية.

\section{لغة اللون الابيض والاسود في نهج البلاغة :}

من المعلوم أن الألوان الأساسية في اللغة العربية هي خمسة ألوان تتمتل باللون الأسود والأبيض

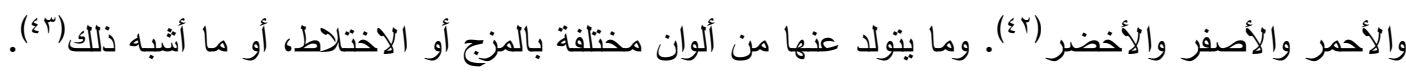

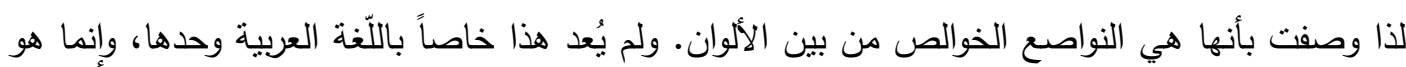

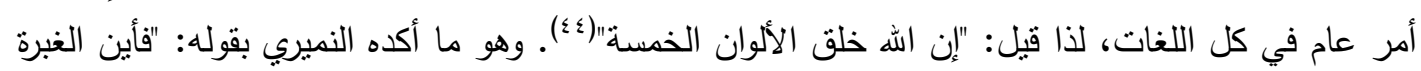

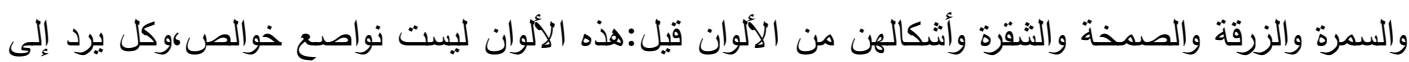

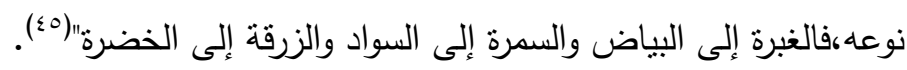

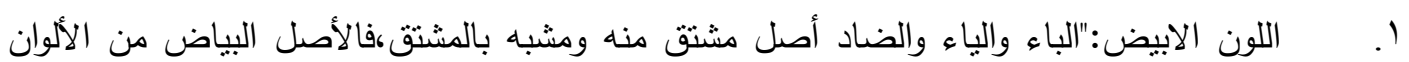

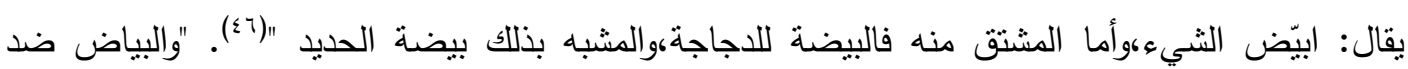

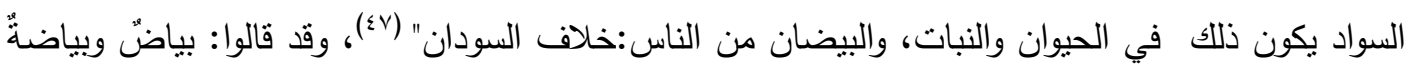

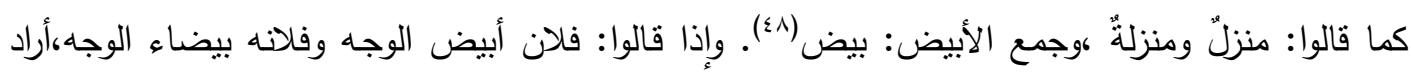

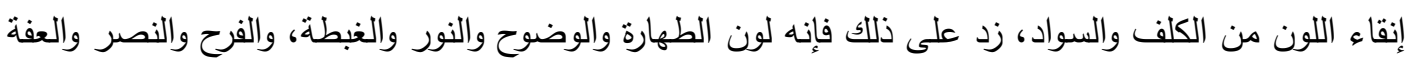

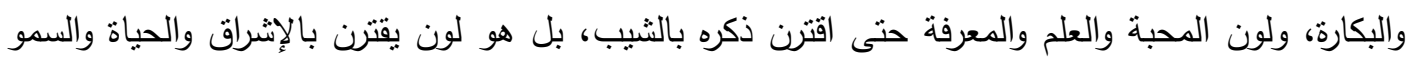


وتجدر الاشارة هنا الى أن دلالة اللون الابيض في التراث العربي قد غلبت عليها الدلالة المجازية،

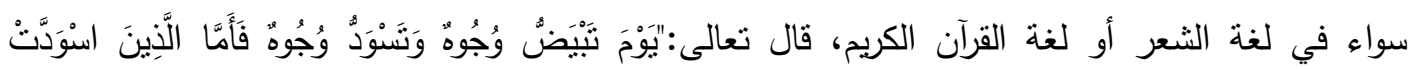

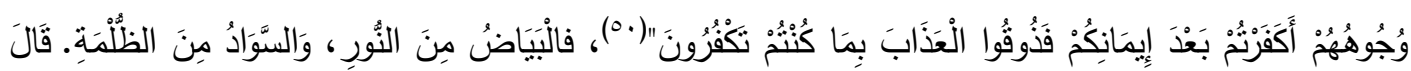

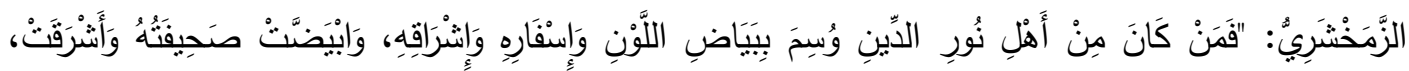

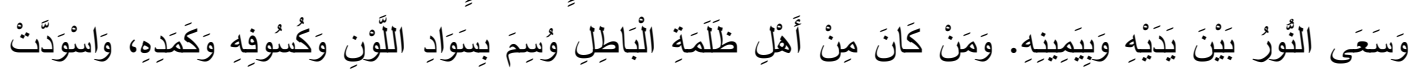

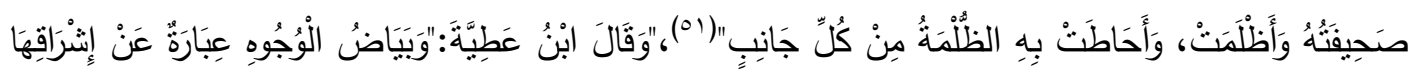

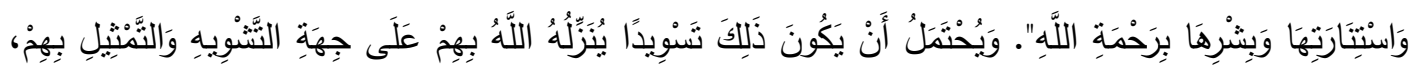

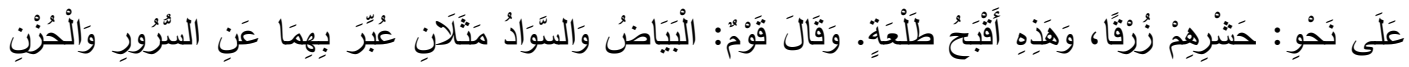

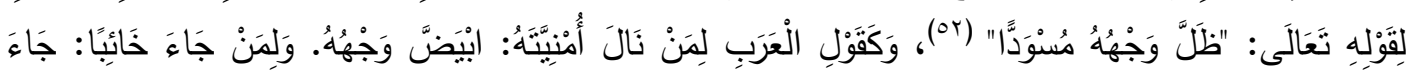

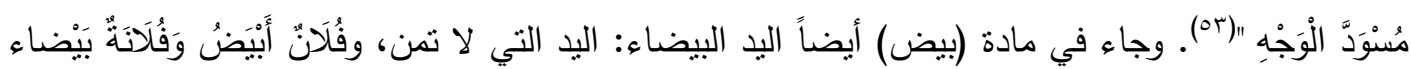

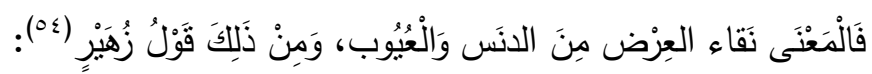

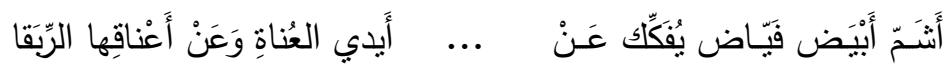
وَقََالَ:

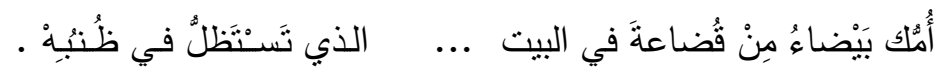
وكنلك ورد في عرف العرب دالاً على الككانة الاجتماعية، وعلى كرم الثخص، قال فئل الثاعر : ومجلس بيض الوجوه أعزة ... حمر اللثاث ، كلامهم معروفُ. (00)

وأما من وجهة نظر سايكولوجية واجتماعية، فاللون الابيض لون الطهارة والخلوص والصفاء والنقاء

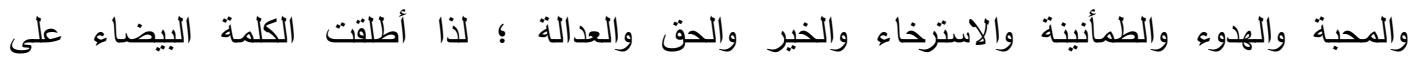

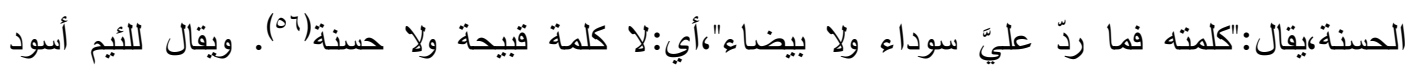

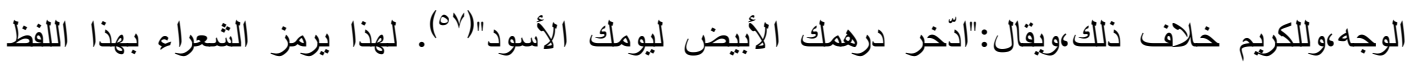

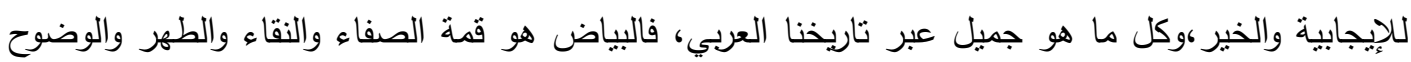
والقبول عند الله، ومن النقيض منه يقف اللون الاسود فهو اللون الذي يدل على قمة القتامة والإعتام واليأس والخيبة،والموت والفناء. 
ارتباطات لغة اللون الأبيض في نهج البلاغة:

للغة اللون الابيض في نهج البلاغة ارتباطان مهمان هما :

الارتباط الاول: وهو الاصل فيما يرتبط به هذا اللون، إذ يرتبط بكل ما هو محبب ومرغوب فيه، زد

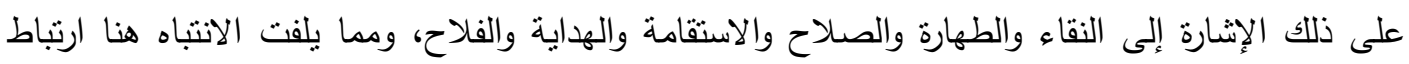

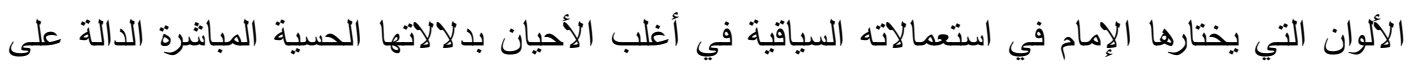

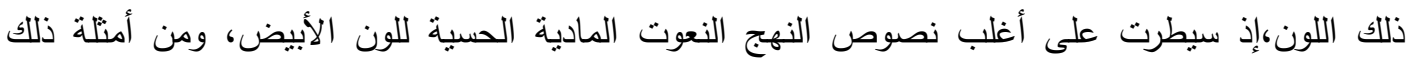

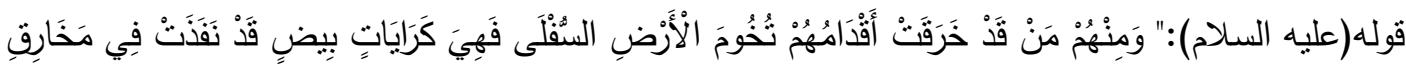

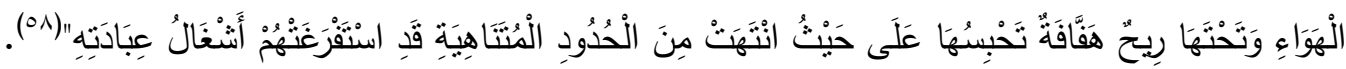

إذ عقد الإمام(عليه السلام) اركان تثبيهه بين أقدام الملائكة والرايات المركزات في تخوم الارض، الفان.

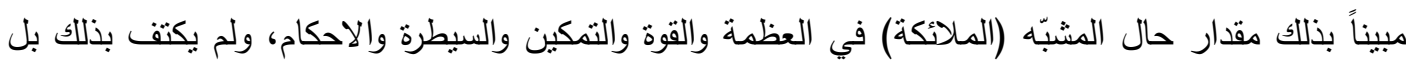

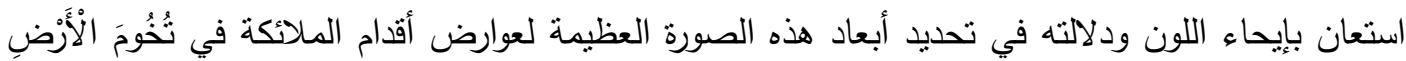

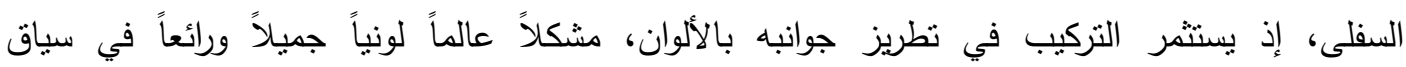

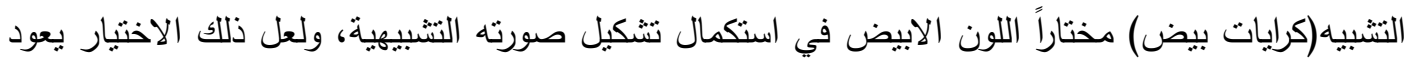

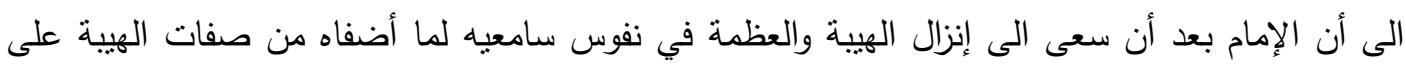

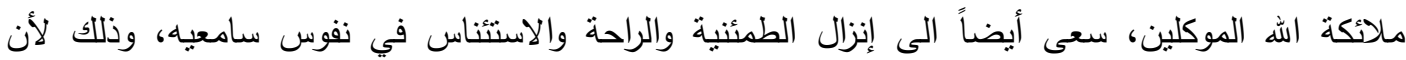

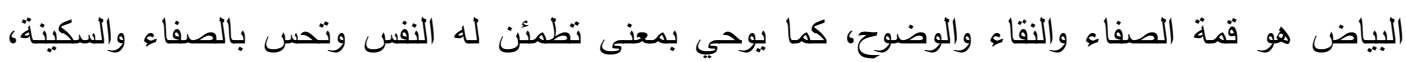

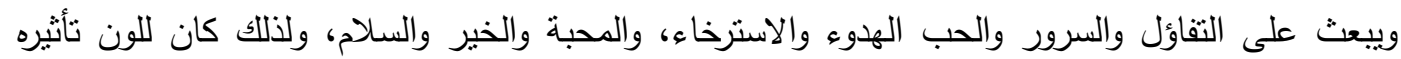

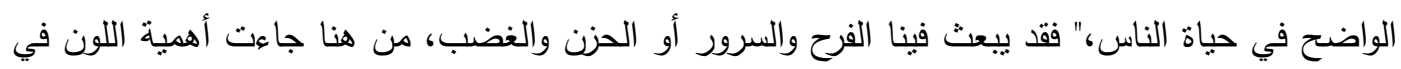

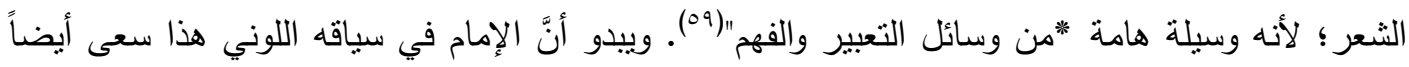

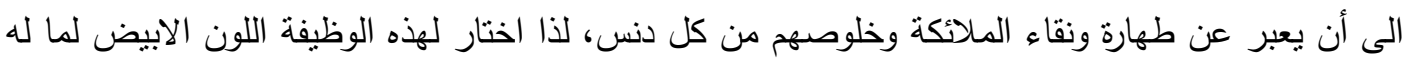

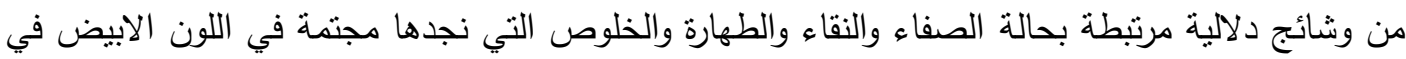

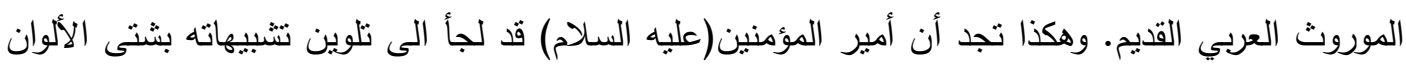
والاضواء المستقاة من البيئة العربية، وحياة العصر الذي عاش فيه، وقد مثل اللون ركناً أساسياً من أركان

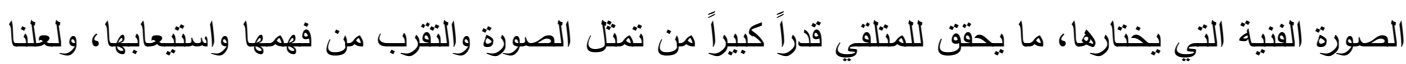


لا نجانب الصواب إذا ما قلنا إن الالوان هنا دخلت في صميم العملية التشبيهية، وإن الالوان هنا شكلت

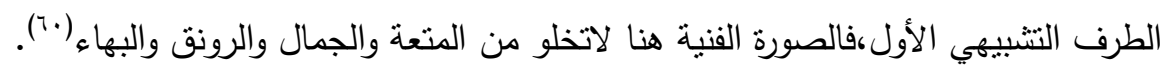

ومن المواطن التي استعمل فيها اللون الأبيض في دلالته اللونية الحقيقية في نهج البلاغة قوله (عليه

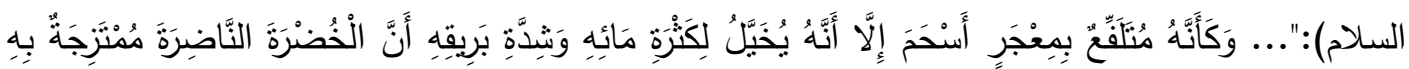

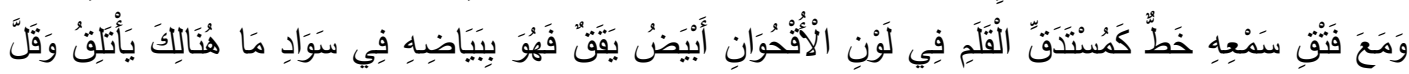

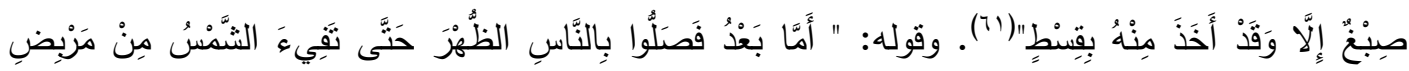

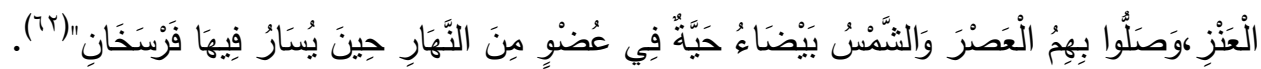

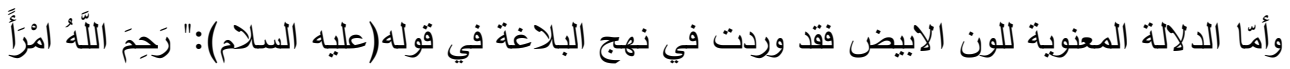

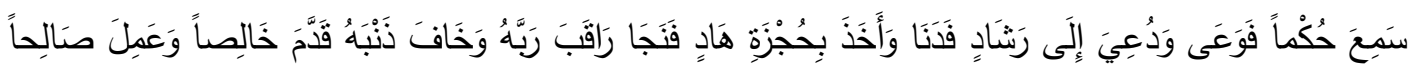

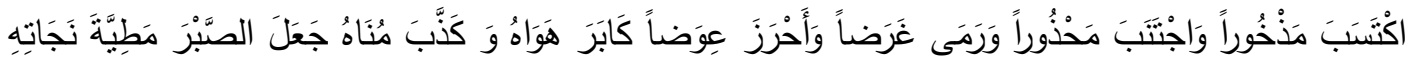

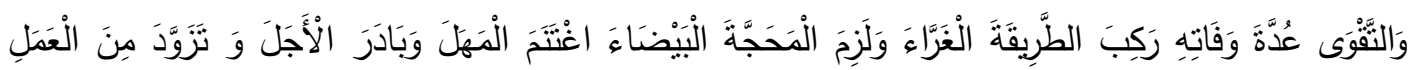
(TT) "...

الدجّة: الجادة الواضحة، والطريق الواسع الواضح والمنهج، والطريق المستقيم، وهي سبيل الحق

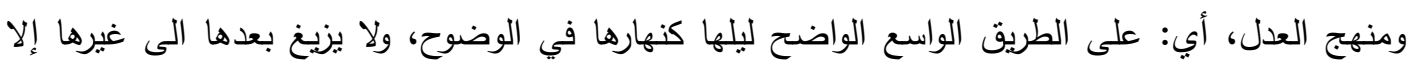

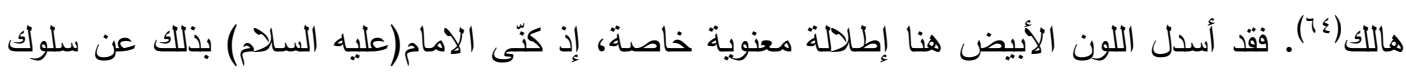

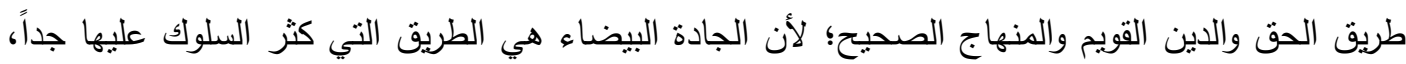

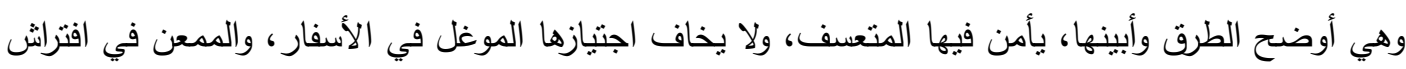

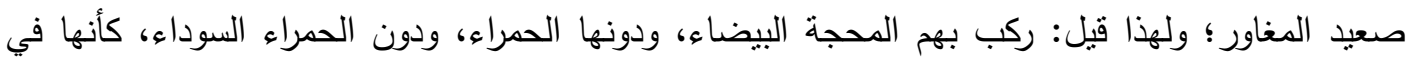
خفائها والتباس معالمها ضد البيضاء في الظهور والوضوح (70).

فاستعمال اللون الأبيض واقترانه بالمحجّة له دلالة رمزية وبعد استعاري، فهو دلالة المسير الناجح

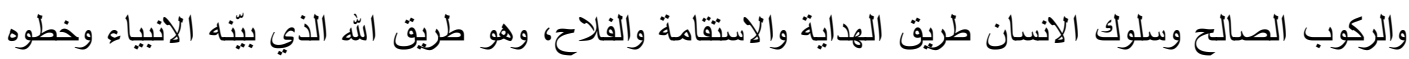

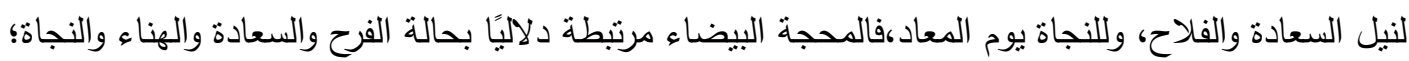

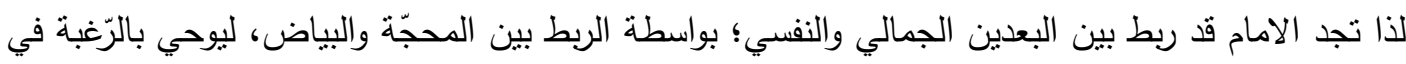

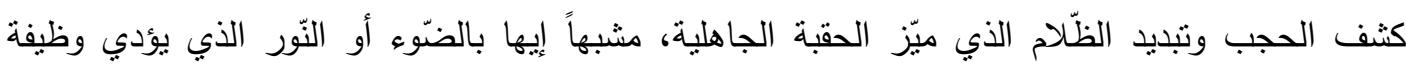


التّوضيح والبيان والكثف، مرشداً المتلقي في تلمّس معالم الطُّريق في هذه الحياة، من خلال دلالات الوضوح

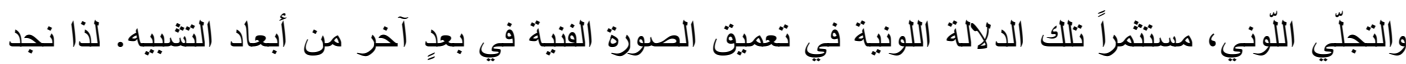

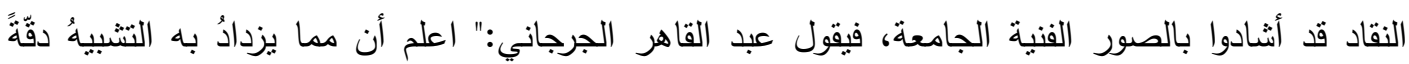

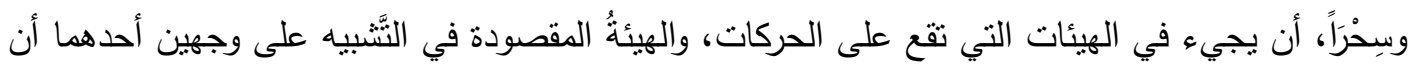
تقترن بغيرها من الأوصاف كالثكل واللون ونحوهما" (17).

ب- الارتباط الثاني: الارتباط السلبي: قد يكون للّون الواحد أكثر من دلالة، وقد تكون له دلالات رمزية

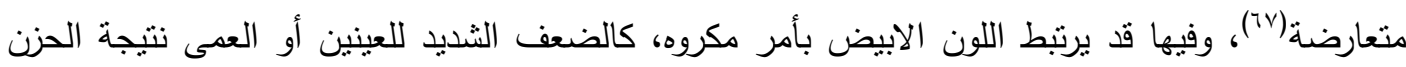

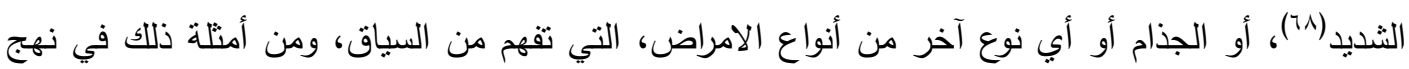

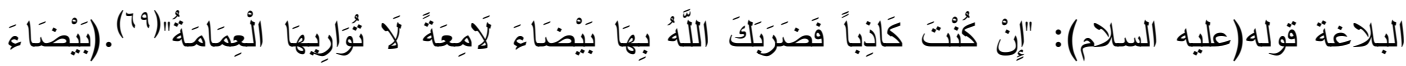

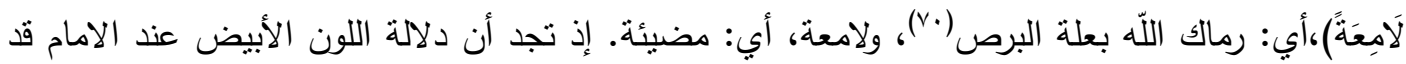

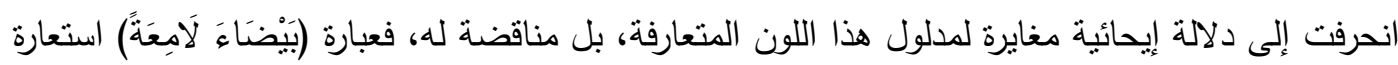

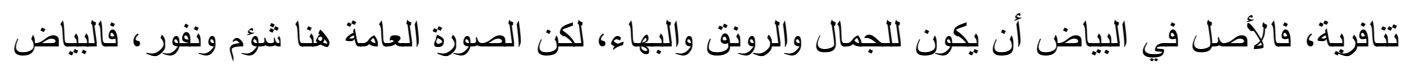

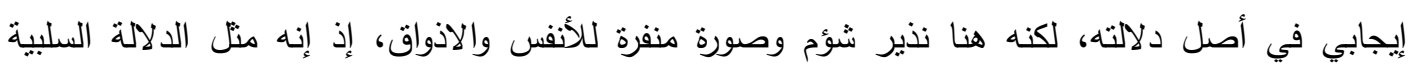
والنتاؤمية المتشثلة بمرض البرص، ذي المنظر المكروه والثكل المشوه المنبوذ، الذي تتفر منه النفوس وتبتعد

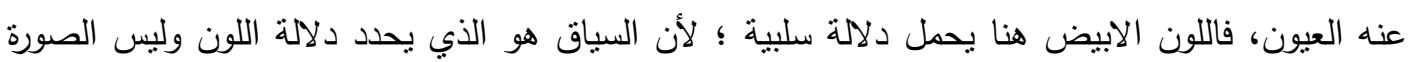

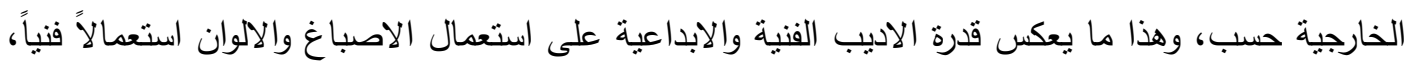

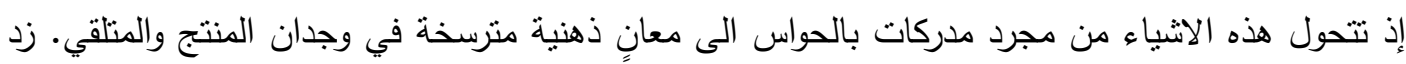

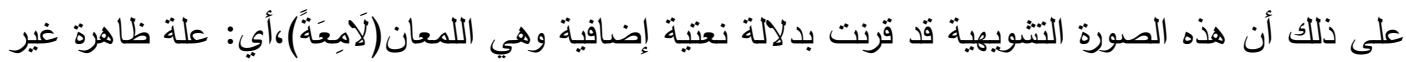

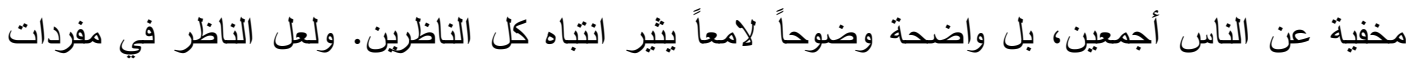
النصّ السياقي اللوني للإمام برى أنّ هناك علاقة مباشرة بين التشويهين (تثويه الحقيقة أمام الناس بكتمانها،

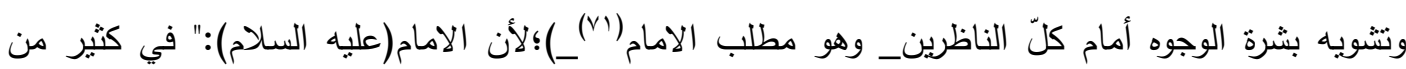

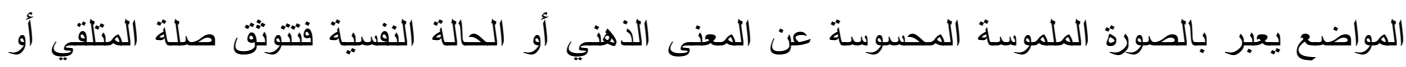

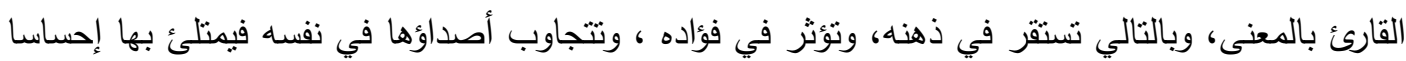

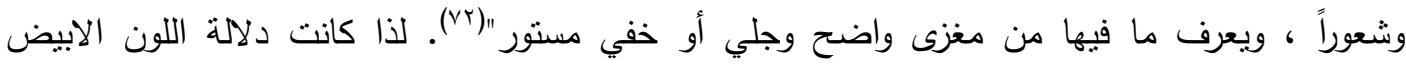

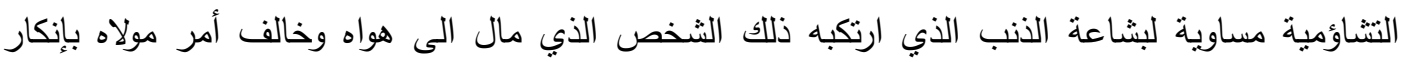


الثهادة أمام مرأى الناس، فدلالة اللون الابيض هنا أخذت دلالة على العكس ما هو متوقع لها، فاللون قد

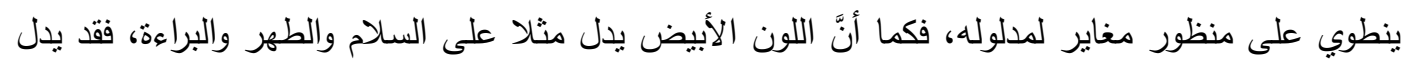

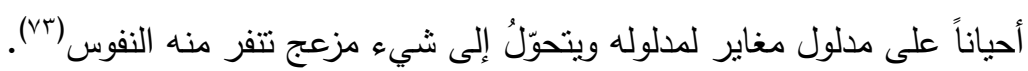

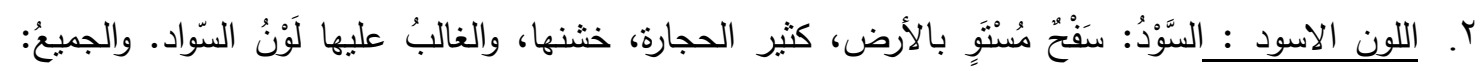

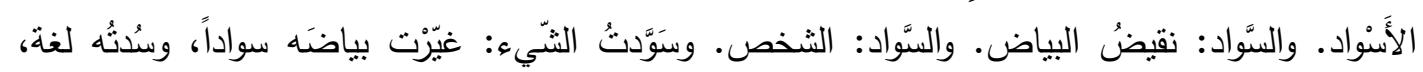

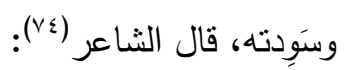

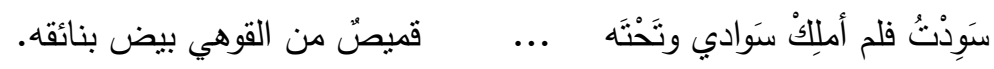

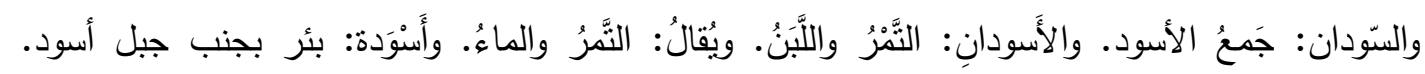

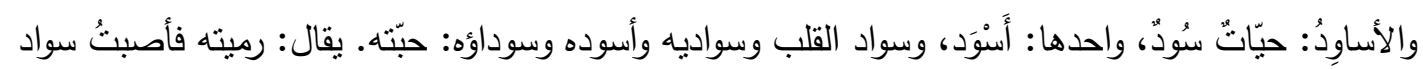

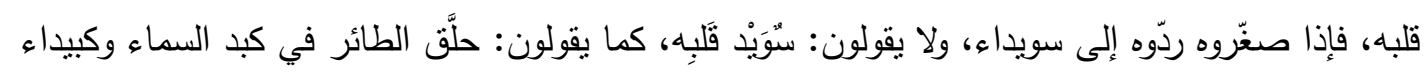

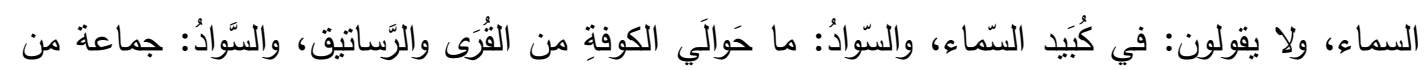

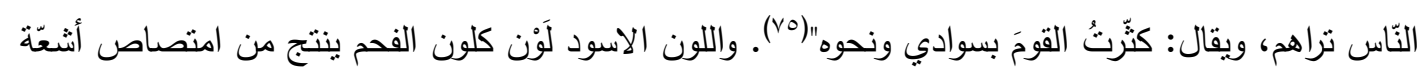

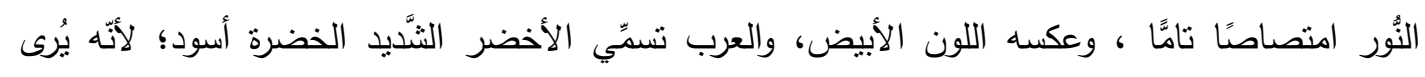

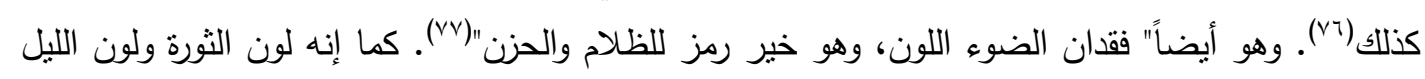

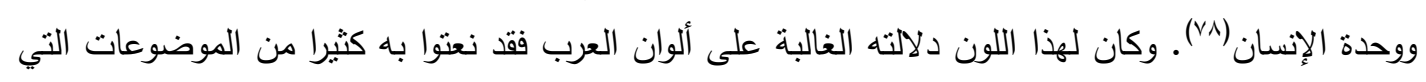

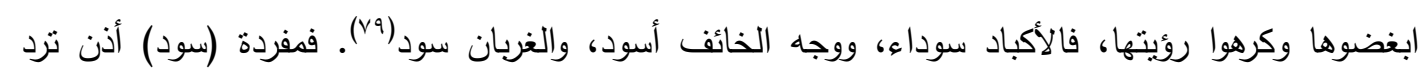

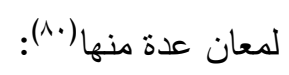

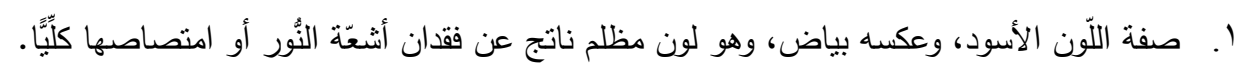

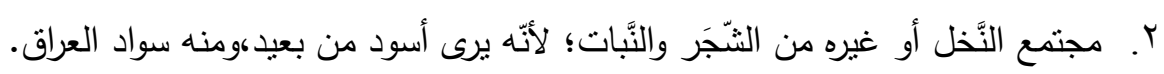

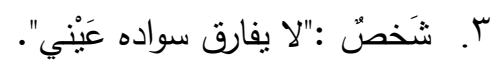

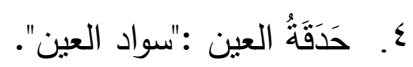

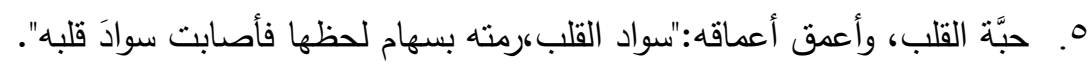

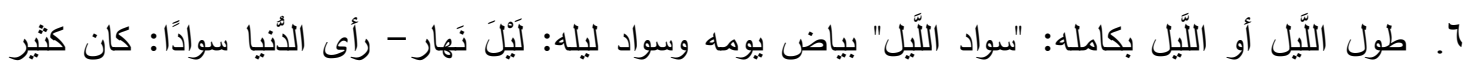
التشاؤم لم تحْلُ الحباة في عينيه. 
V. معظم النَّاس: (السّواد الأعظم) وسواد المدينة: ما حولها من القُرى والرّيف.

وتجدر الاشارة هنا إلى أن اللون الاسود قد يكون محبباً للنفس أحياناً لدى العرب وذللك حسب

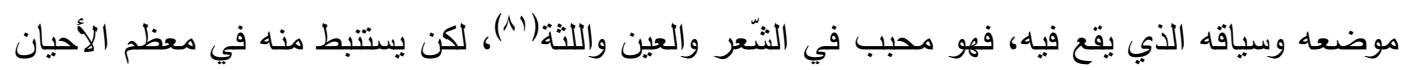

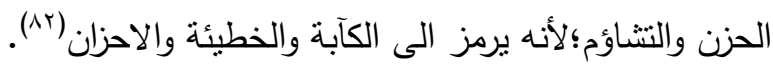

\section{ارتباطات اللون الأسود في نهج البلاغة:}

للغة اللون الأسود في نهج البلاغة ارتباطان مهمان هما :

أـ الارتباط الاول: الارتباط السلبي: وهو الاصل فيما يرتبط به هذا اللون، إذ يرتبط بكل ما يرمز الى الحزن

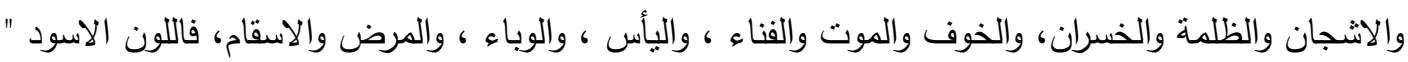

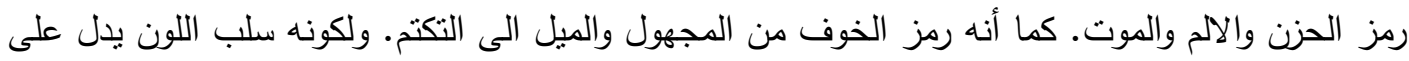

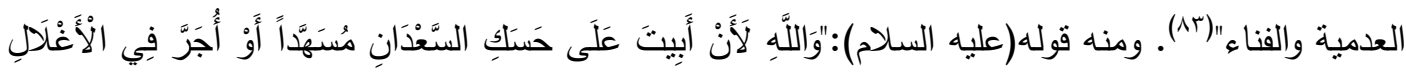

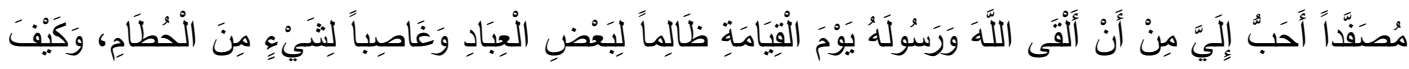

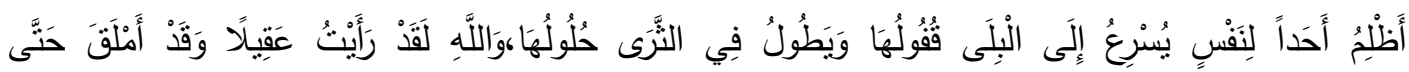

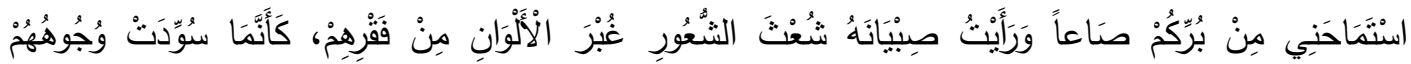

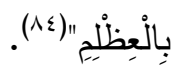

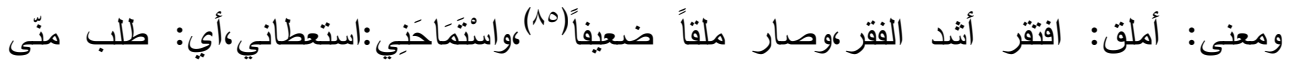

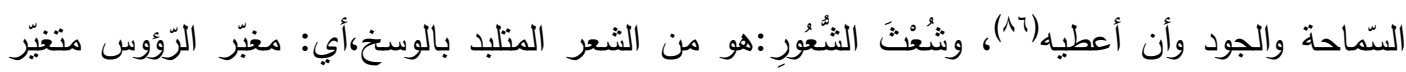

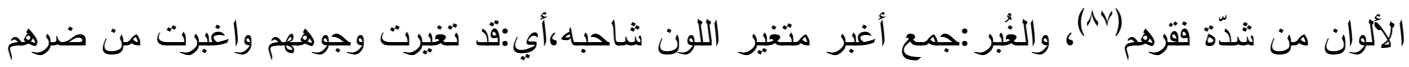

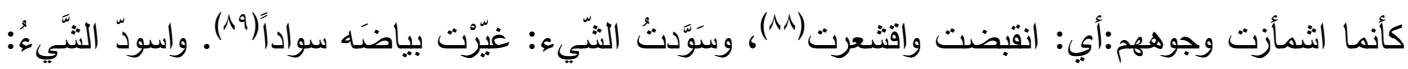

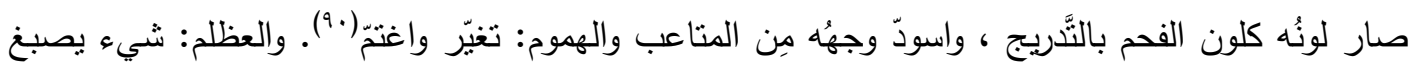

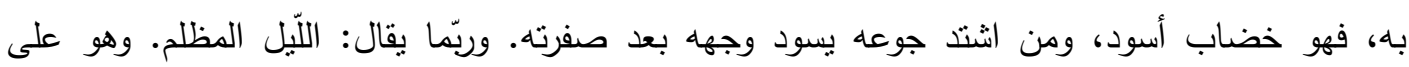

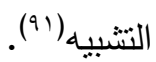

يسترسل الامام (عليه السلام) في رسم صورتين للوحته الفنية _التبرؤ من الظلم_: الصورة الاولى الفى

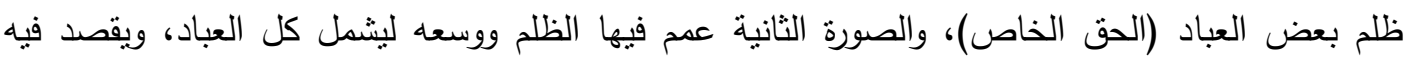


الحق العام الذي هو لعامة المسلمين، وهذا بمكن غصبه أو أخذه في حال كونه حاكما للمسلمين، ومتسلطاً

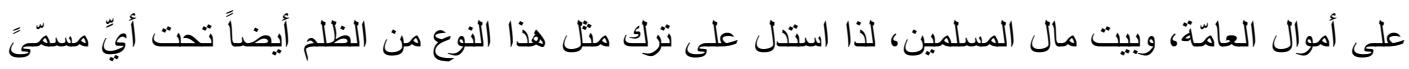

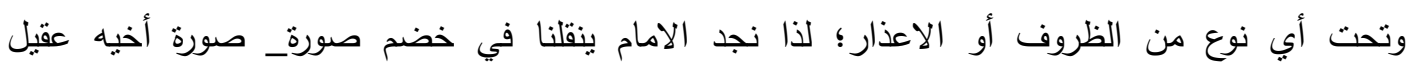

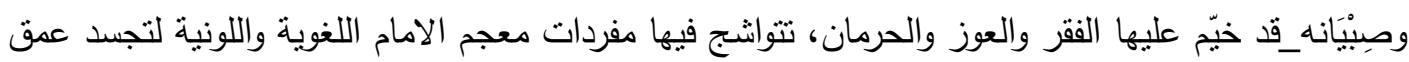

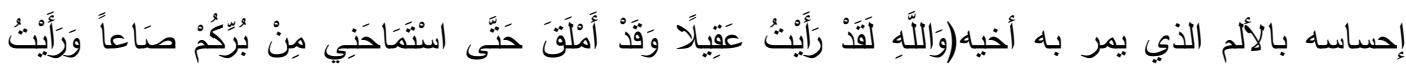

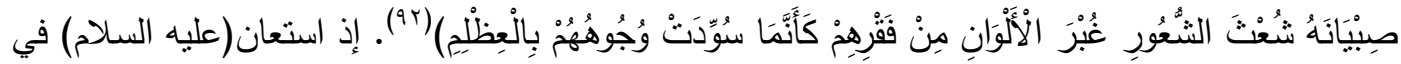

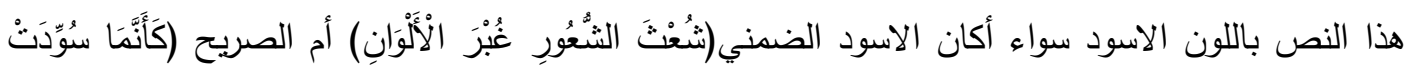

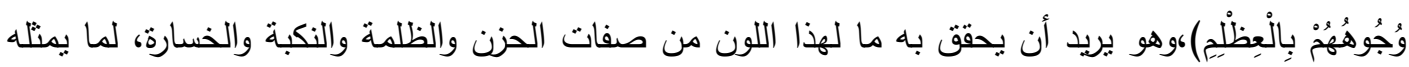

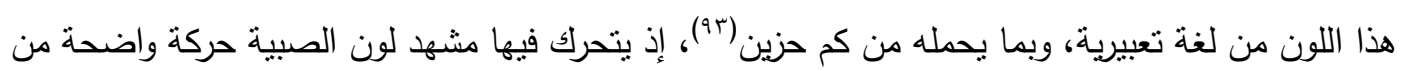

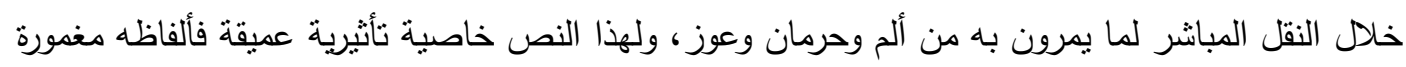

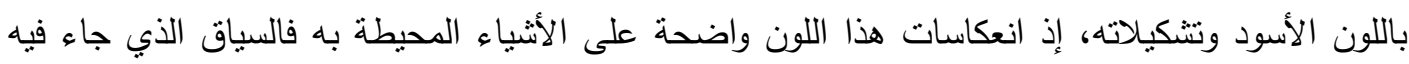

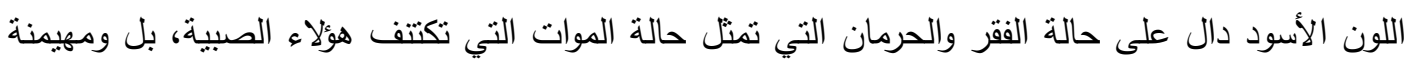

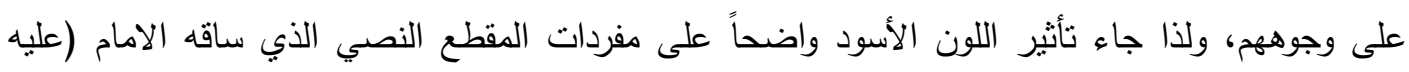

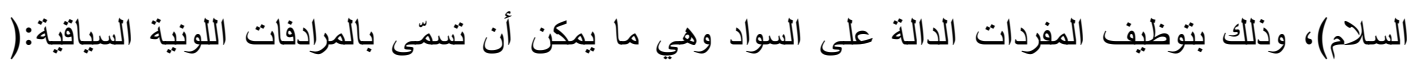

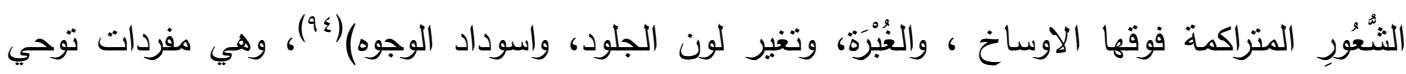

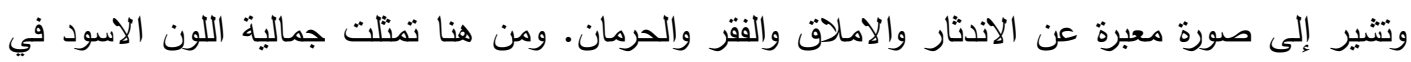

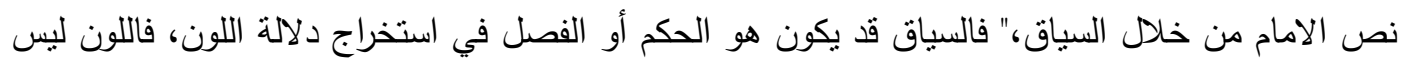

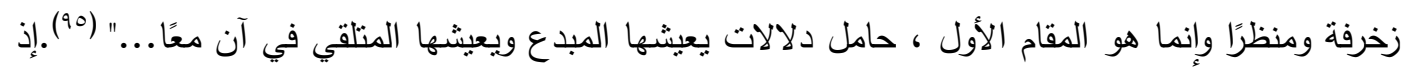

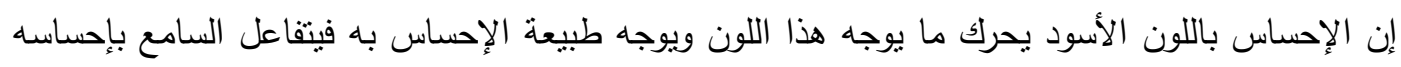

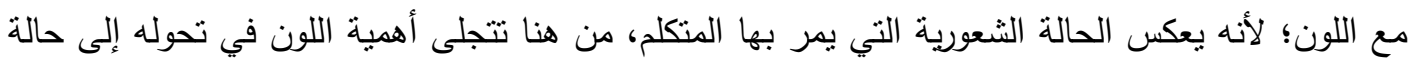

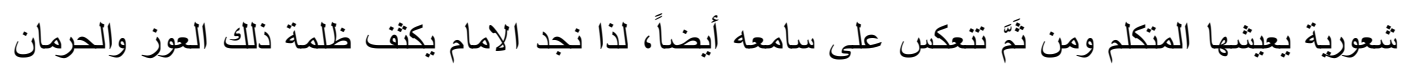

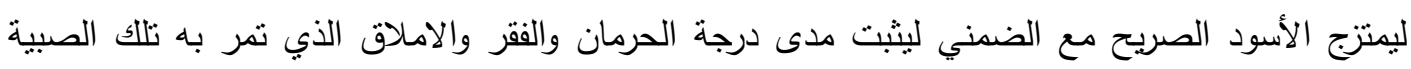
وأبوهم المسكين.

وعلى الرغم من هذا المشهد المأساوي والحزين لا نجد الامام الا صلب الايمان، نافذ البصيرة، صلدا

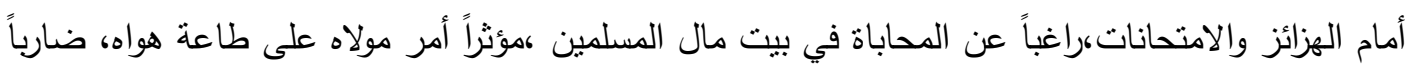




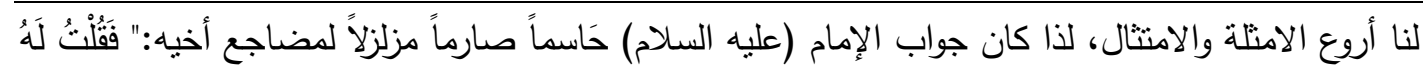

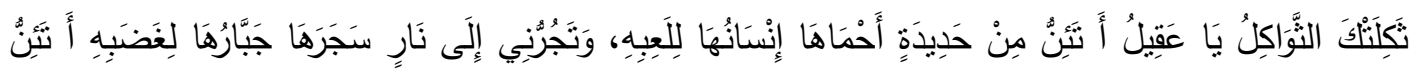

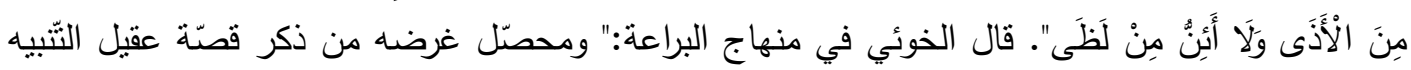

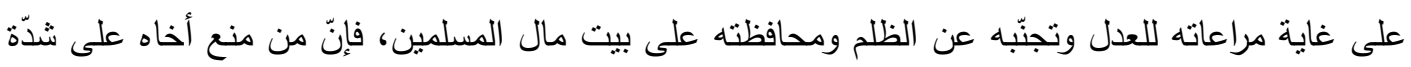

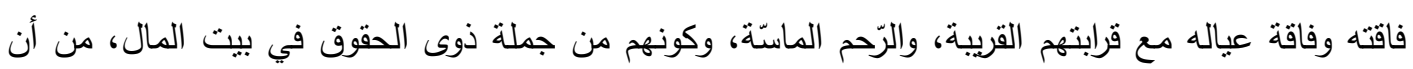

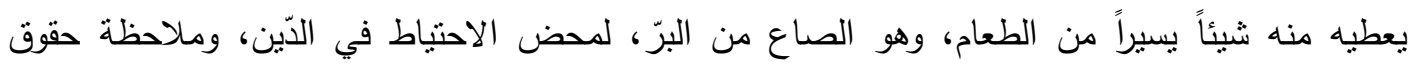

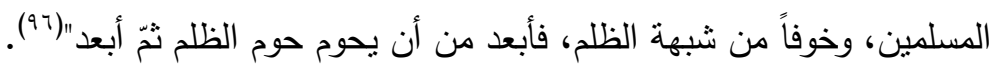

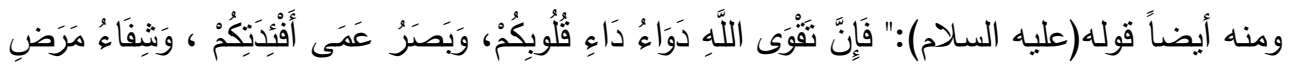

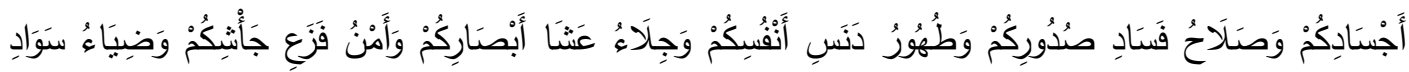

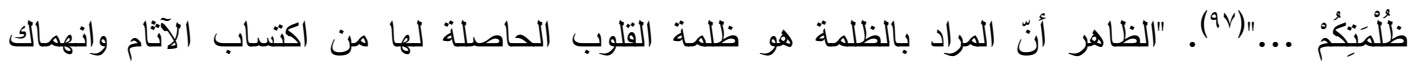

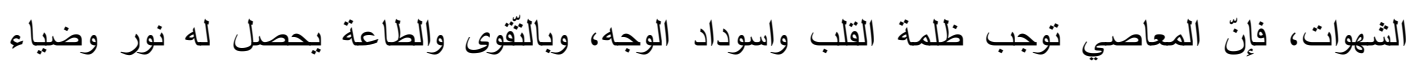

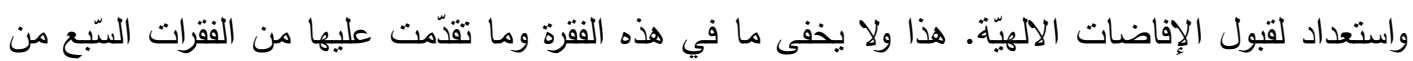

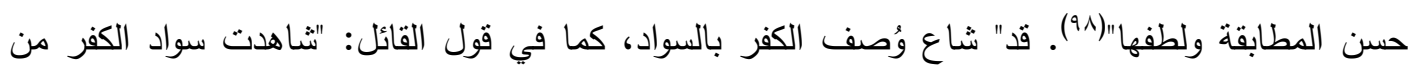

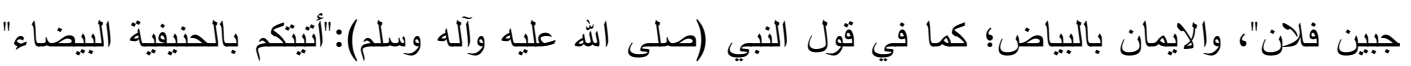

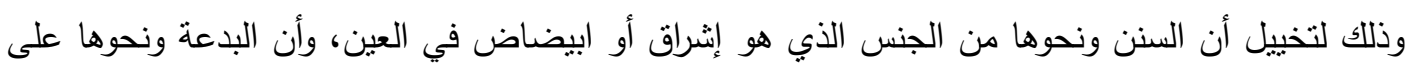

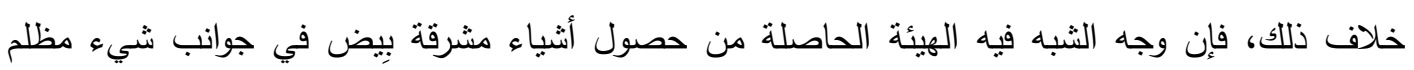

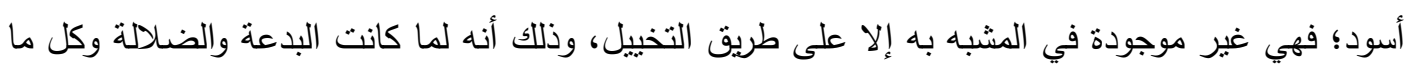

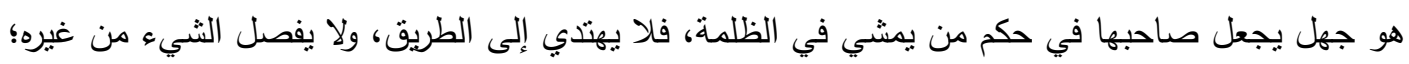

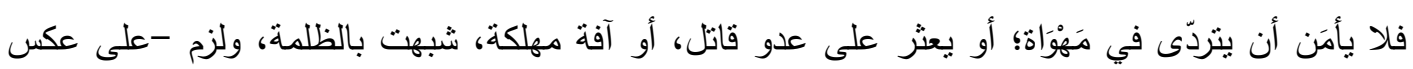

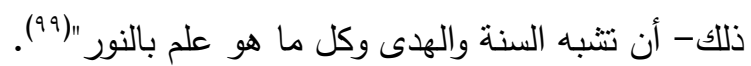

فالسواد هنا استعارة عن اكتساب المعاصي والآثام والانهماك في الثهوات، والضياء التزام جادة

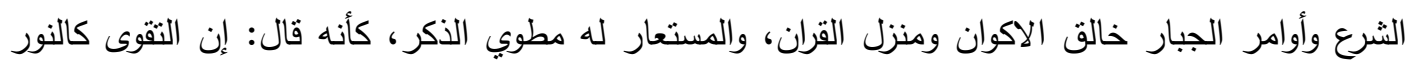

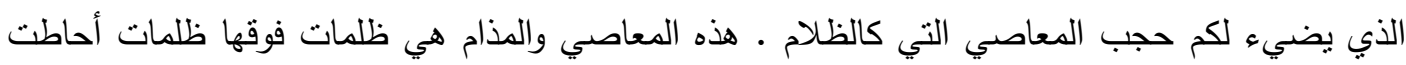
بذلك الانسان عندما ينغمس في الثهوات ويغور في ملذات الهوى والثيطان، واذا ما اجترأ على اله بارتكاب الهاب 


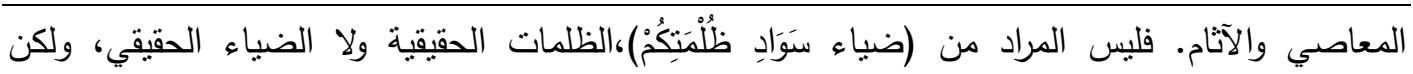
الظلمات الرراد بها هنا هي ما فيه الانسان من ضلال وانحراف وتجاوز وطغيان وتعد على حدود الله وقوانين

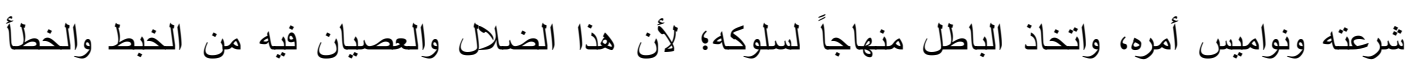

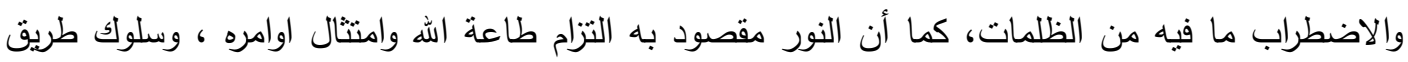

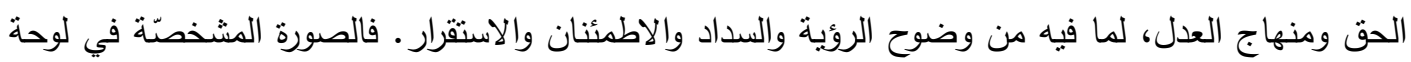

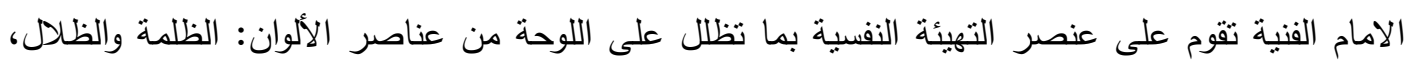

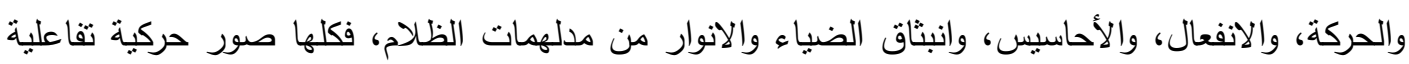

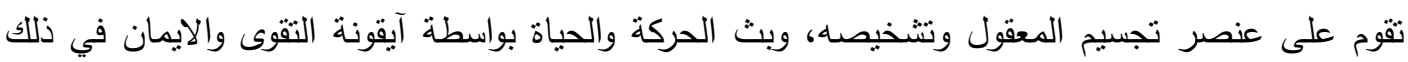
الجسد الذي كان أسيراً للشهوات وارتكاب المحارم والآثام، ليصبح ذللك الجسد ذا حياة مستقلة لها قيمنها وأثرها

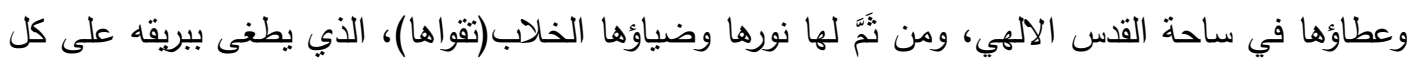

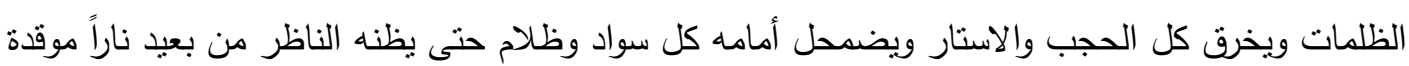
بذلك الضياء. كل هذا المشهد قد نسجه أمير المؤمنين(عليه السلام) بالاعتماد على الألفاظ الموحية بالحركة

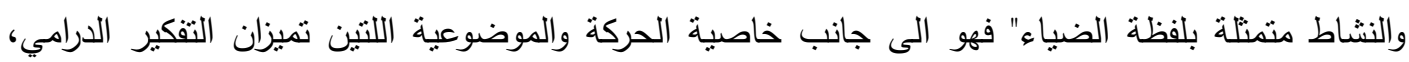

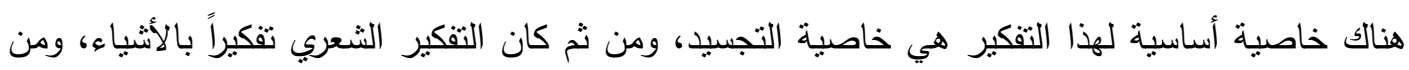

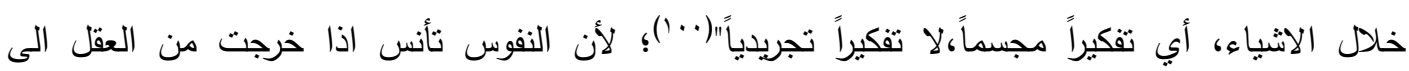

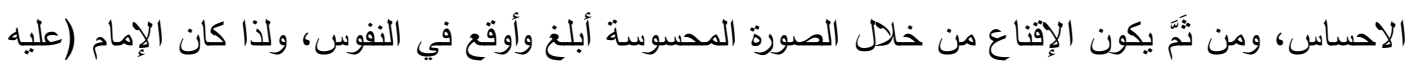

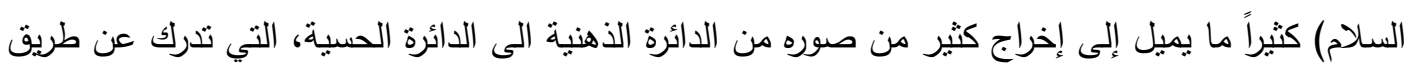

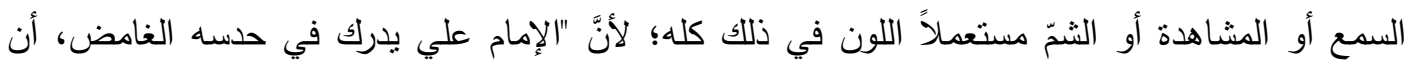

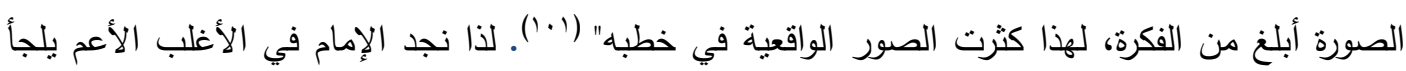

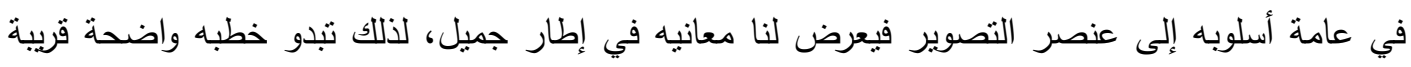

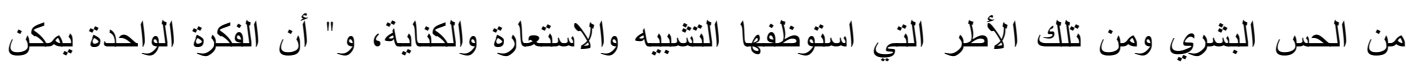

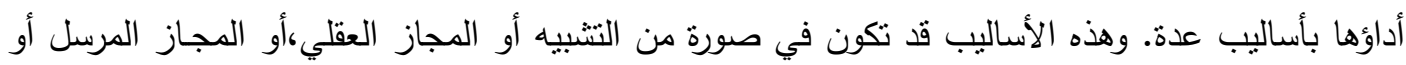

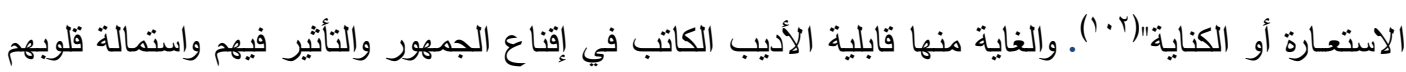

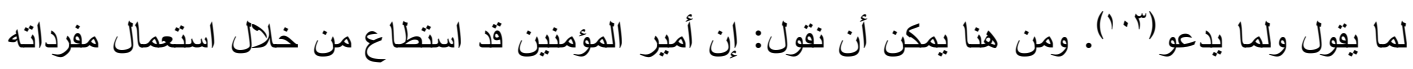


اللونيه في سباقاته النصبة أن يجِق وظيفة اللون الاولى التي تكمن في توصيف المشهد، وله إيحاء في

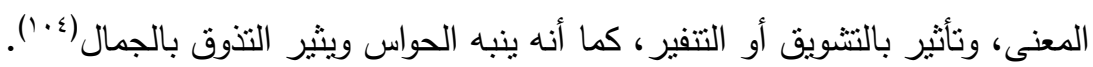

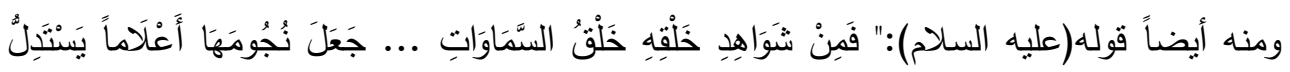

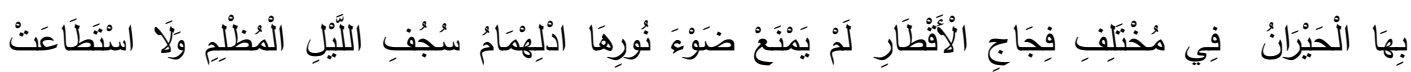

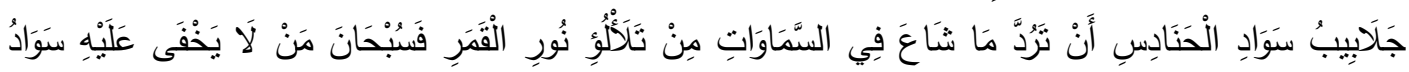

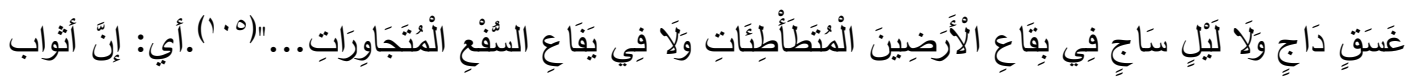

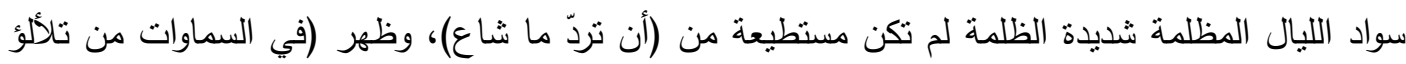

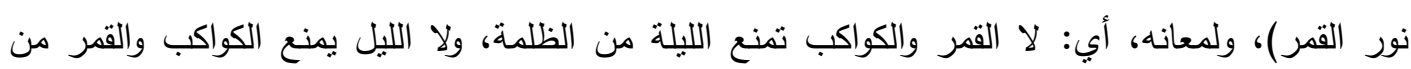

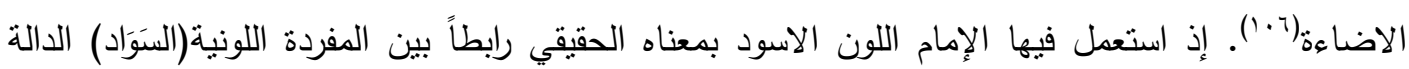

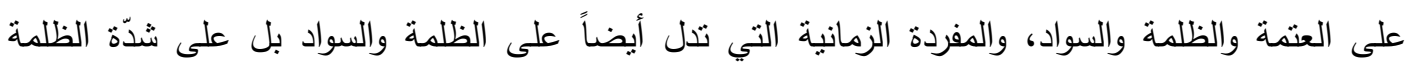

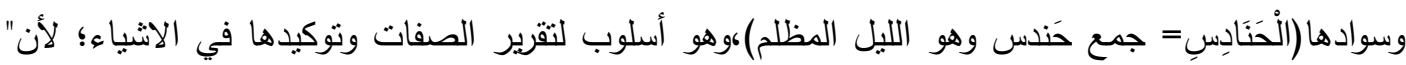

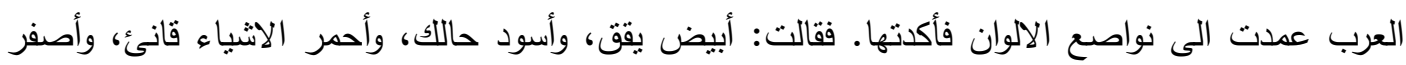

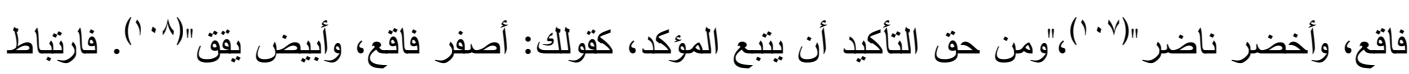

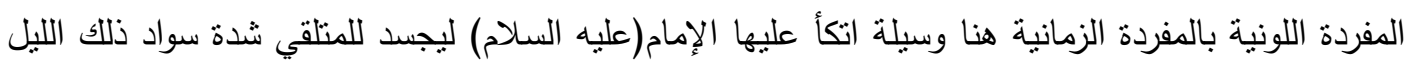

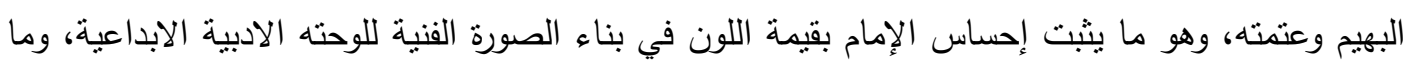

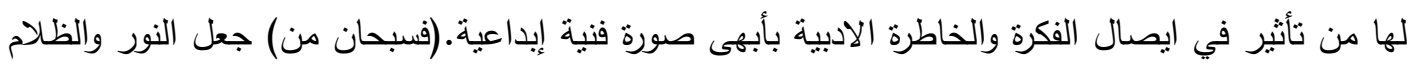

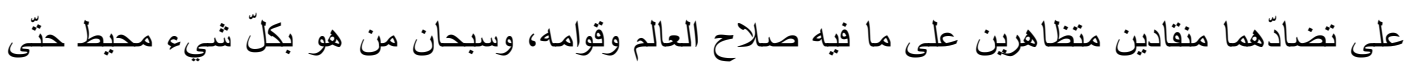

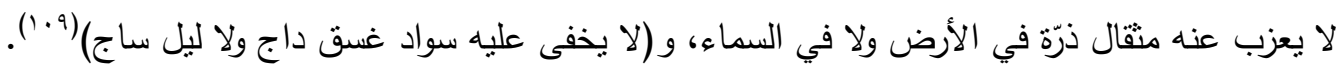

بـ الارتباط الثاني: الارتباط الإيجابي: إذ يرتبط فيه اللون الاسود بدلالات ايجابية مرغوب بها تحمل مقبولية لدى

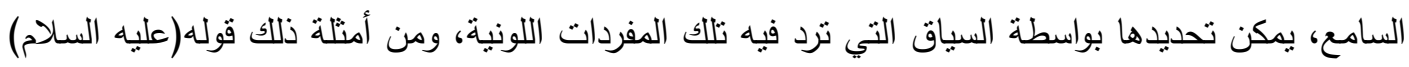

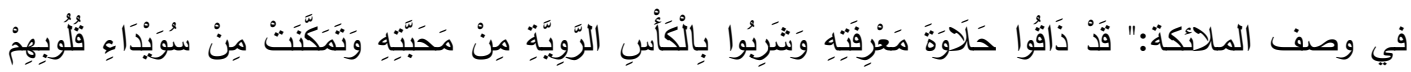

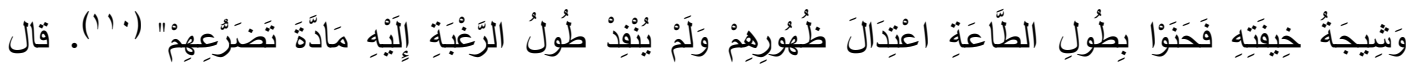

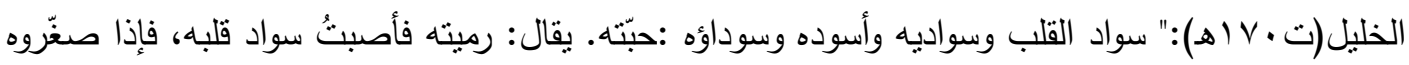

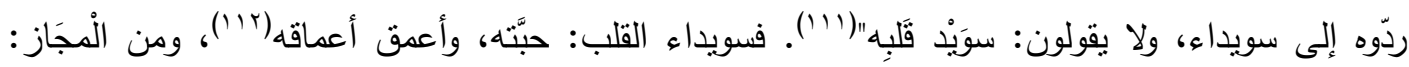




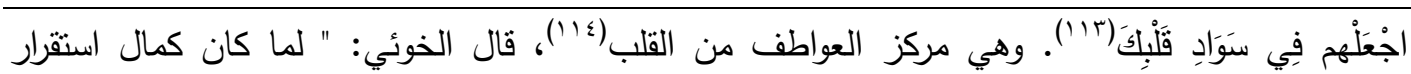
العوارض القلبيّة من الحبّ والخوف ونحوهما عبارة عن بلوغها إلى سويداء القلب وتمكنها فيها عبّر عليه

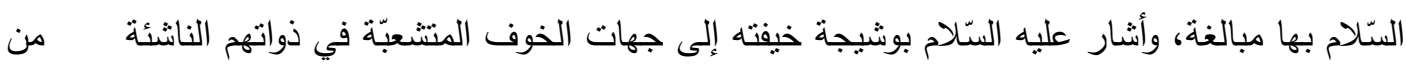
زيادة معرفتهم بعزّته وقدرته ومقهوريّهم تحت قوّتّه" (110)

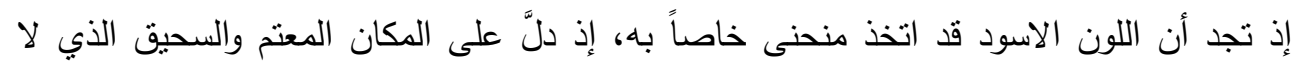

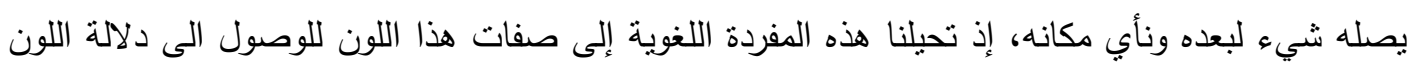

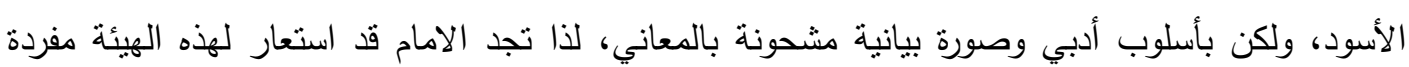

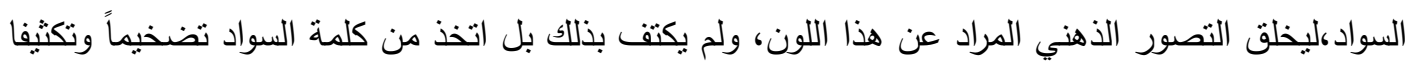

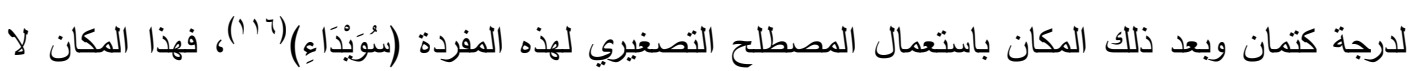

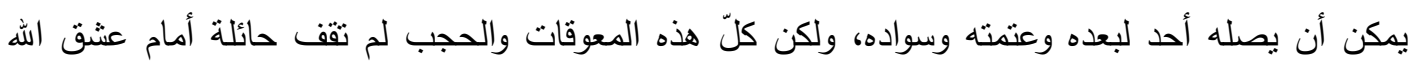

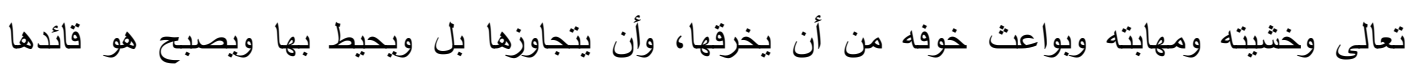

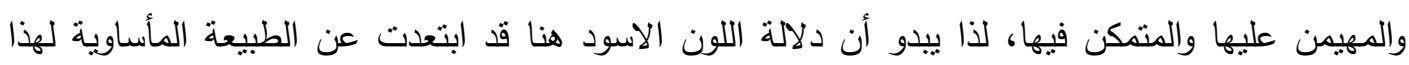

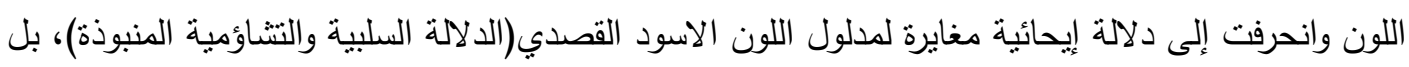

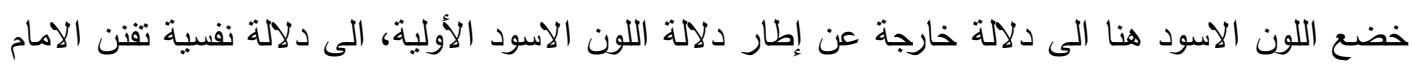

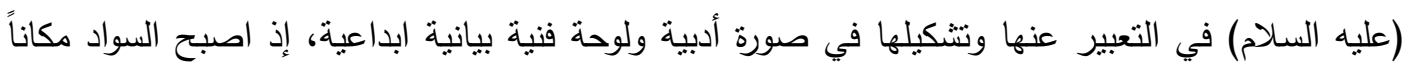

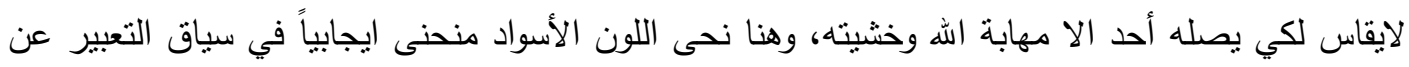

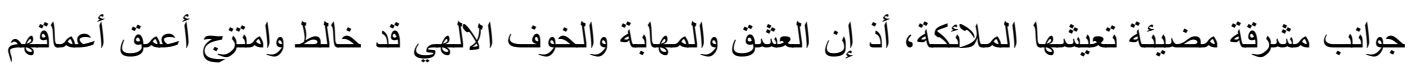
والاماكن النائية من أجسادهم بل كل حيثياتهم، وكل ذرة من ذراتهم. وهنا تنبرز مقدرة الامام(عليه

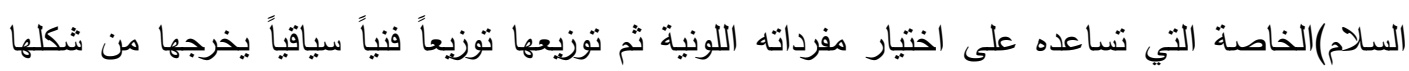

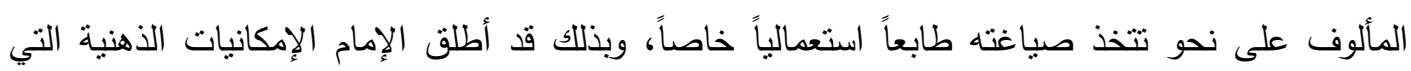
يحققها هذا اللون إلى أقصاها محققا بذلك توظيفا متمكنا لهذا اللون. 
دلالة اللون الاسود على العدد :

ومن الدلالات الايحائية التي استعملها العرب وضمنوها اللون الاسود هي الدلالة على الكثرة العددية

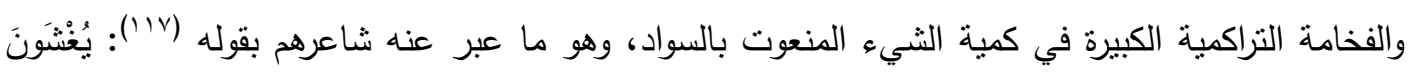

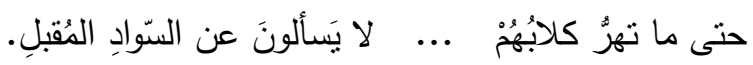

يغشاهم الطالبونْ والسائلونْ ويكثرون عندهم، حتى كلابهم لكثرة ما ترى ممن لا تعرف قد أنست

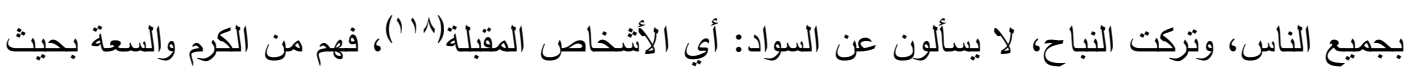

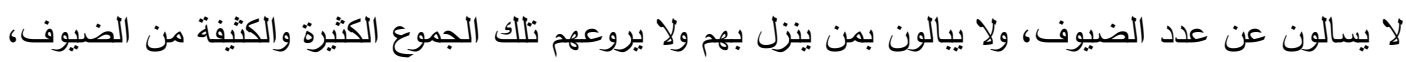

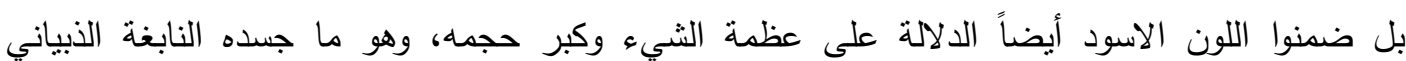

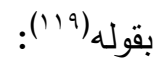

\section{له بفناء البيت سوداء فحمة ..أقم أوصال الجزور العراعر.}

إذ كنى النابغة بالسوداء عن القدر الكبيرة والعظيمة الني يطهون بها الذبائح، دليلاً على كرم المددوحين،

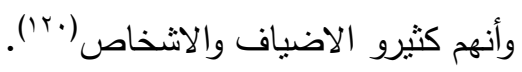

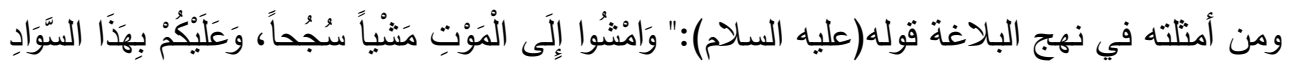

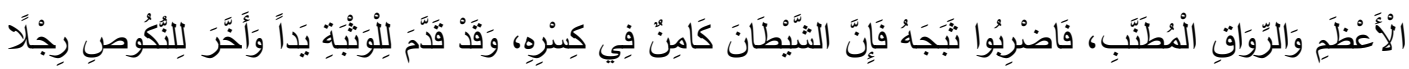

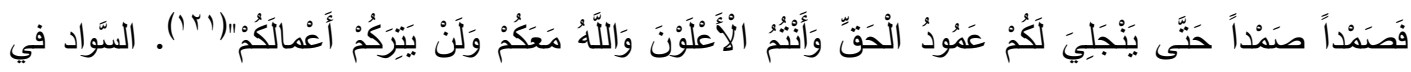

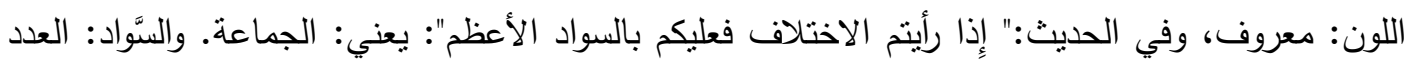

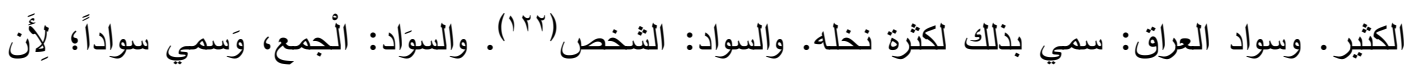

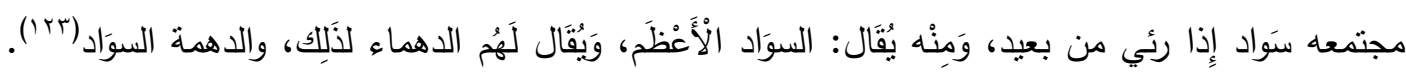

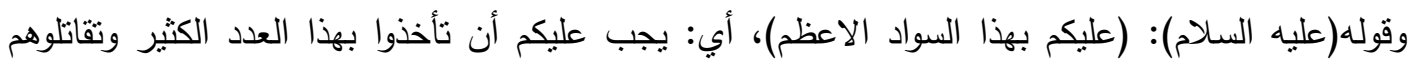

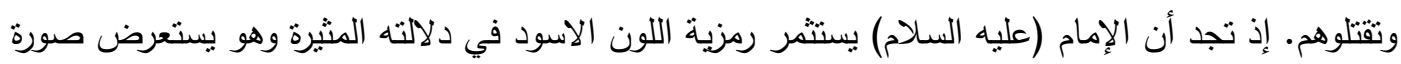

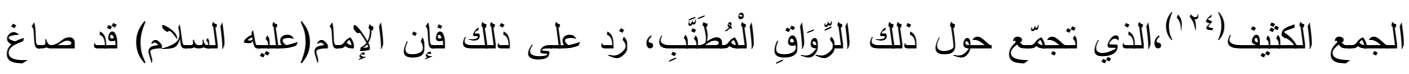
صورته صياغة جمالية بوعي ساهدت في تركيز المعنى وتكثيفه عند المتلقي،إذ أعطى تركيزاً لونياً أكثر الركام 
بواسطة استعمال المفردة المعجمية(الأعظم)(ro() في سياق(السواد الاعظم) ذات الدلالة التفخيمية التكثيرية،

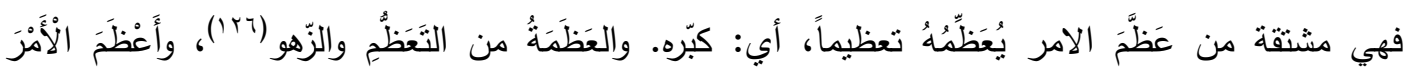

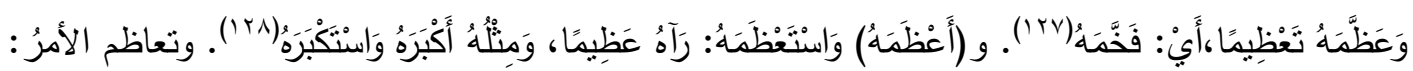

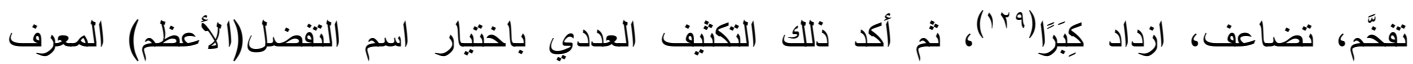

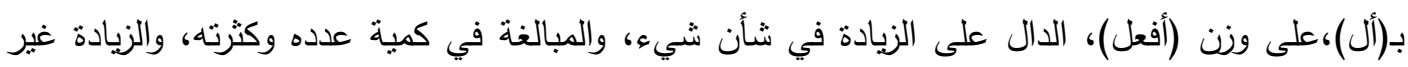

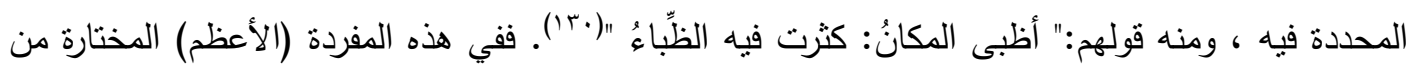

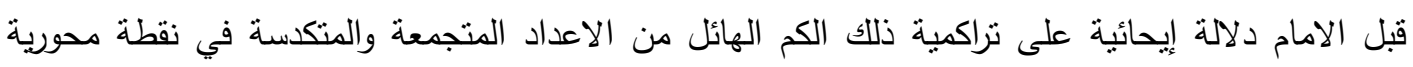

$$
\text { محددة (خيمة معاوية). }
$$

ولعلنا لا نجانب الصواب اذا ما قلنا أن السياق اللوني الذي ساقه الامام في نصّه (السواد الاعظم)،

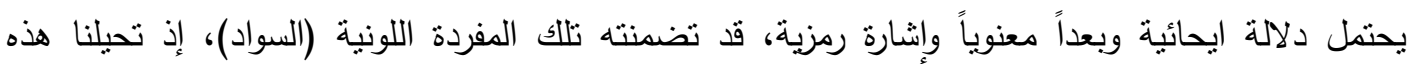

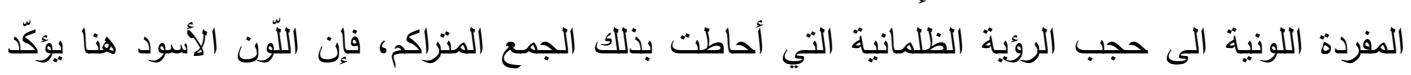

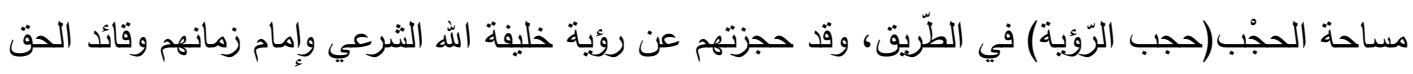

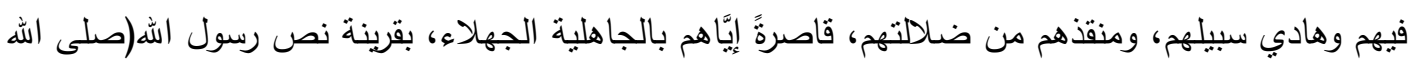

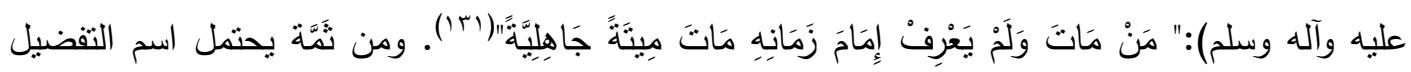

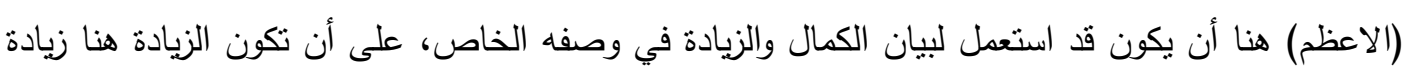

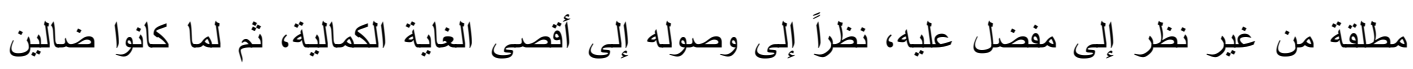

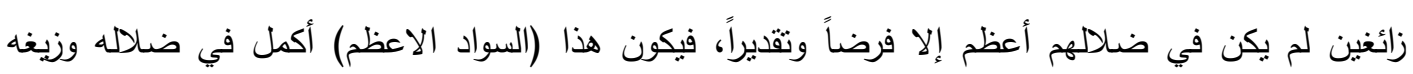

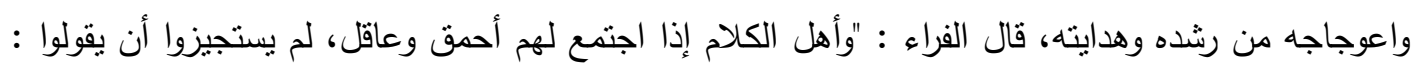

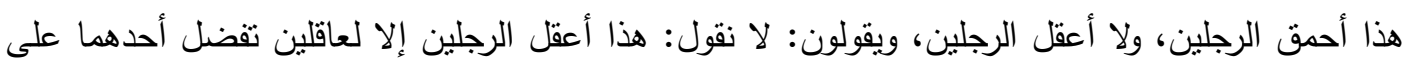

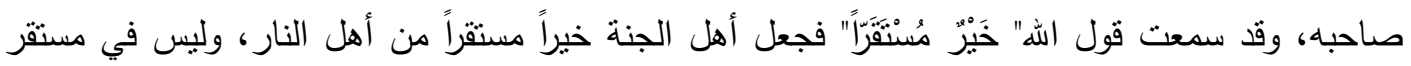

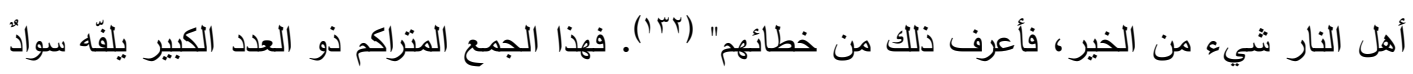

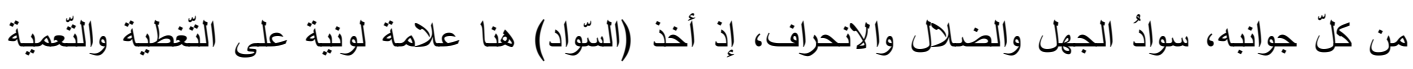

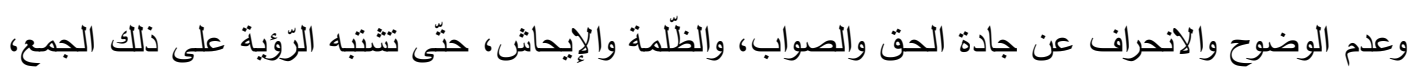

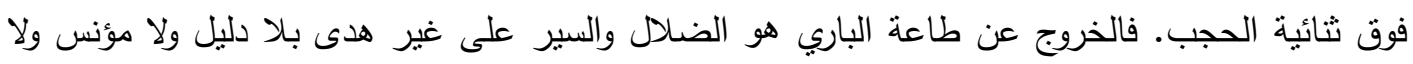

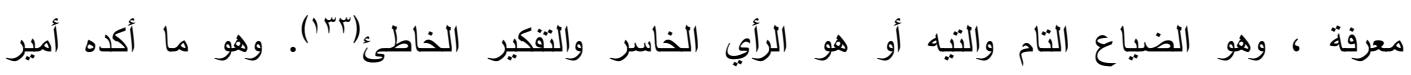




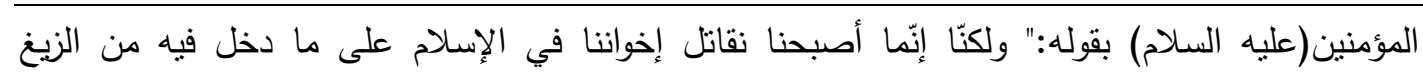

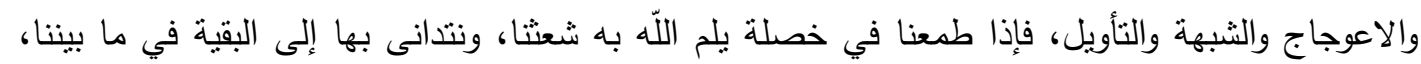

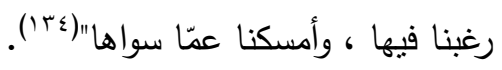

الدراسة الإحصائية:

المخطط البياني الآتي يبيِّن تدرّج تواتر اللونين الأسود والأبيض في نهج البلاغة :

\begin{tabular}{|c|c|}
\hline عدد وروده في نهج البلاغة & اللون اللون \\
\hline$(1 r 0) 1$. & اللون الاسود \\
\hline ד & اللون الأبيض \\
\hline
\end{tabular}

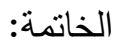

إن فكرة التشكيل اللوني في نهج البلاغة تدرجت بوصفه رمزاً ودلالةً من النطاق المادي إلى النطاق

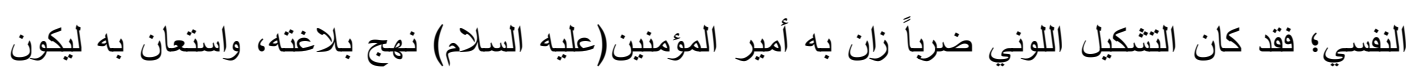

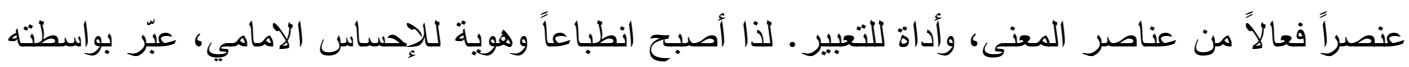

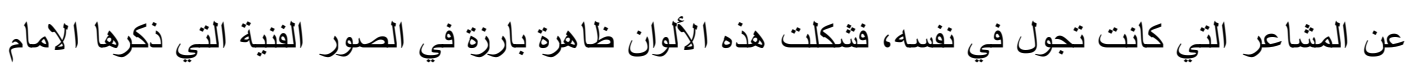

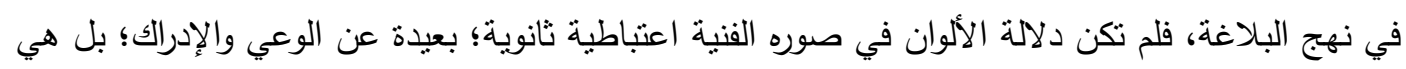

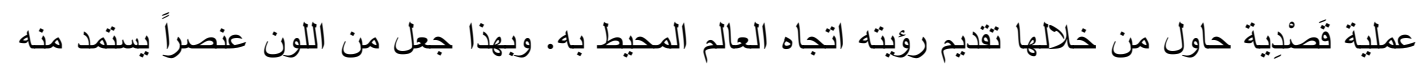

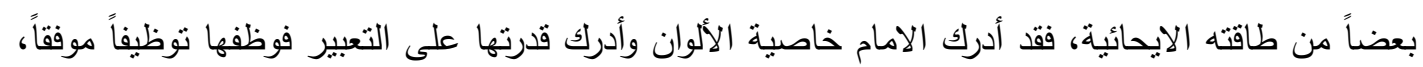

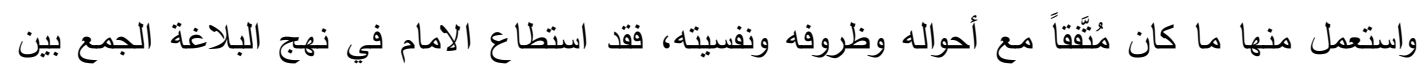

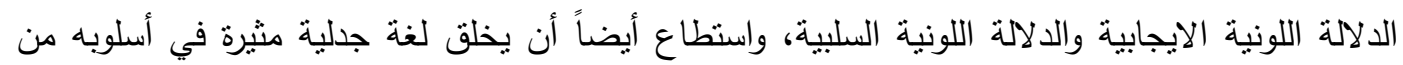

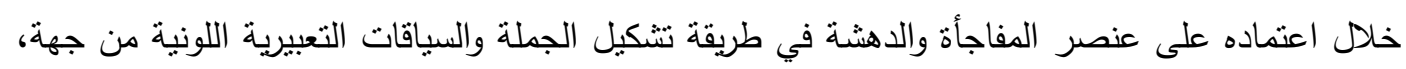
وطريقة قلب المداليل وعكسها من جهة ثانية، ليؤكّد مهارته الفنية، وقدرته على الخوض فئه في أثنكال الكتابة الإبداعية كلها . 
ولابد من الاشارة هنا الى أن الشعراء الجاهليين كانوا يستعلون اللون في معنى وضعي وحقيقي

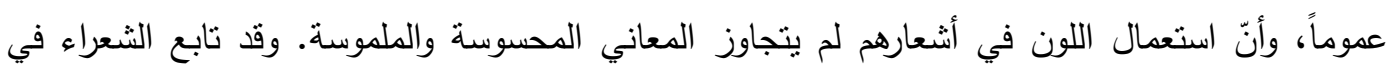

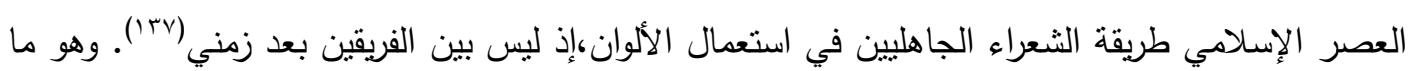

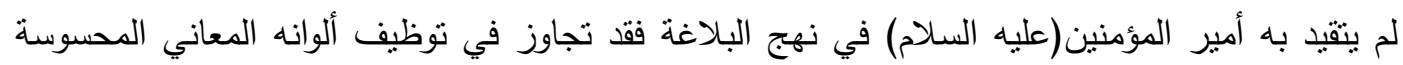

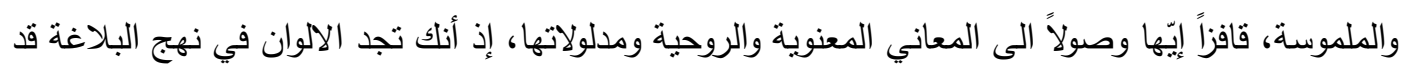

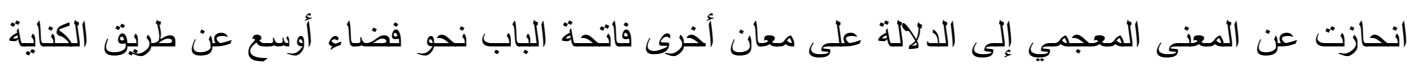

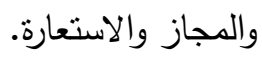

الهو امش

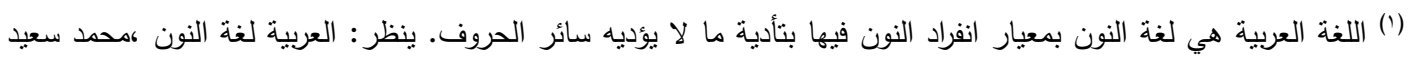

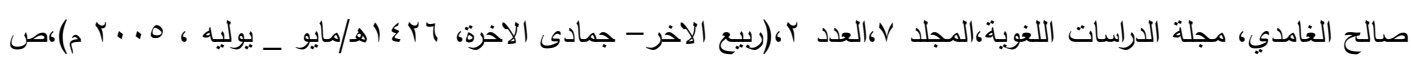
r.

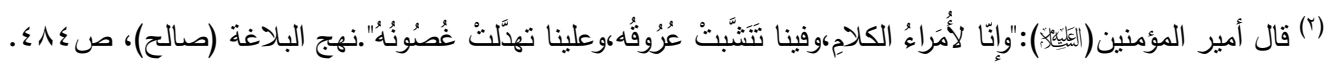

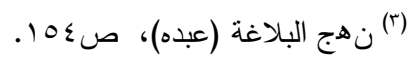

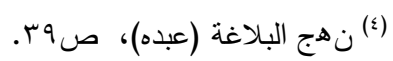

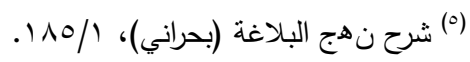

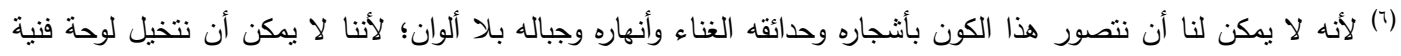

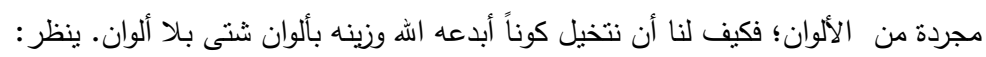

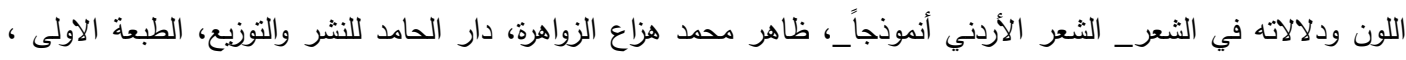

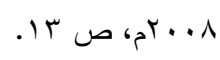
(") الجمال اللوني في الشعر العربي من خلال التتوع الدلالي ، حاجي آبادي وآخرون ، (فصلية محكمة)، دراسات الأدب الباب

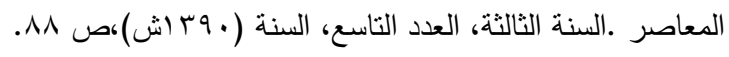

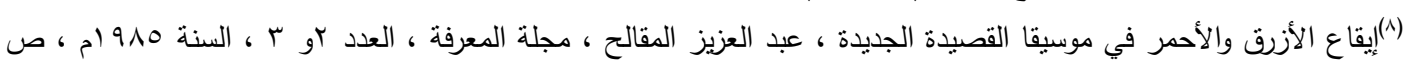

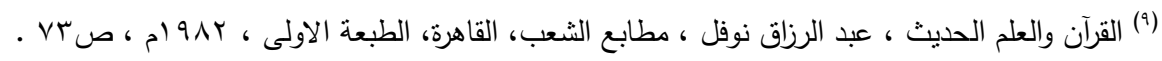

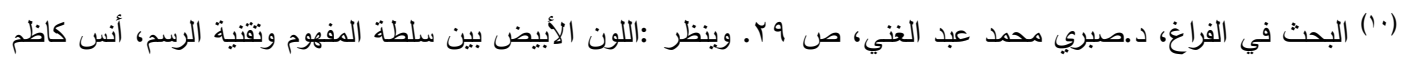

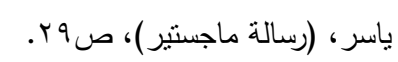

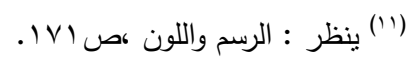


(rا') لعل (كتاب الخيل) لأبي عبيد معمر بن المثىى (ت 9. rهـ) من أقدم ما وصل الينا من المصنفات اللغوية التي أفردت مكاناً

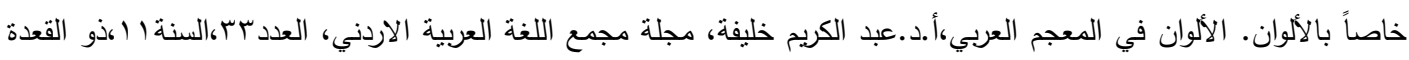

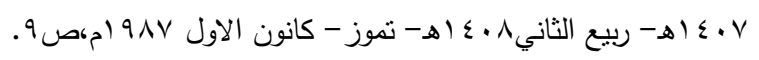

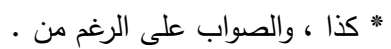

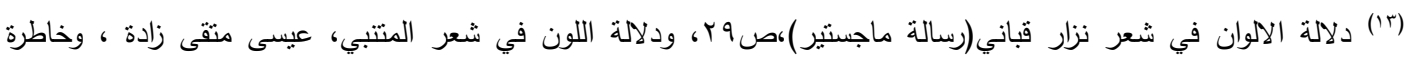

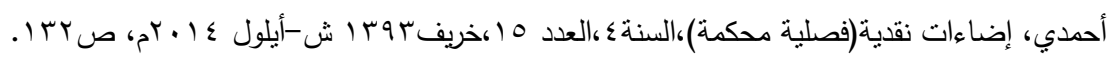

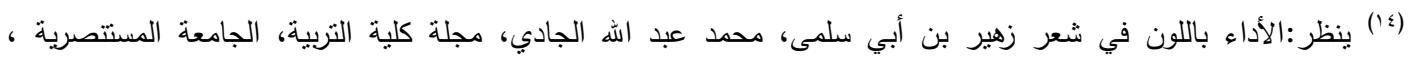

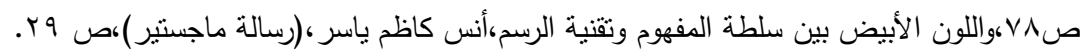

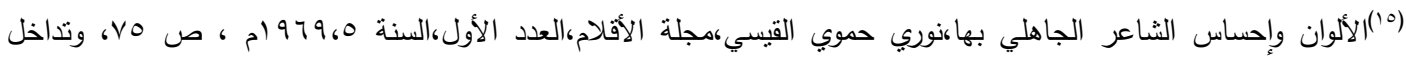

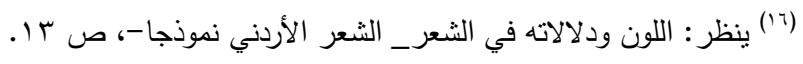

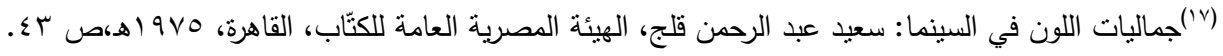

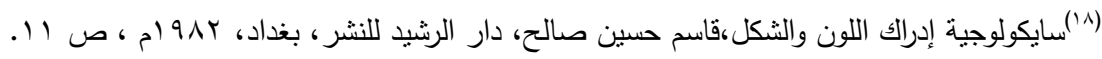

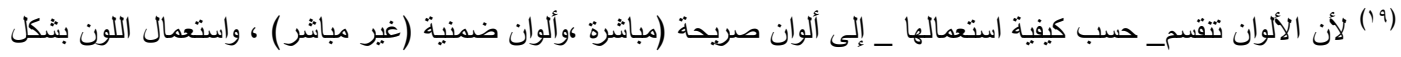

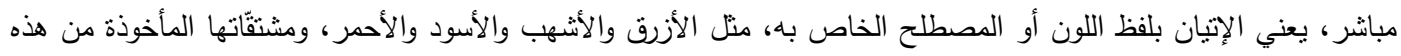

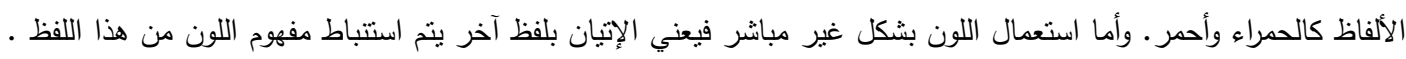

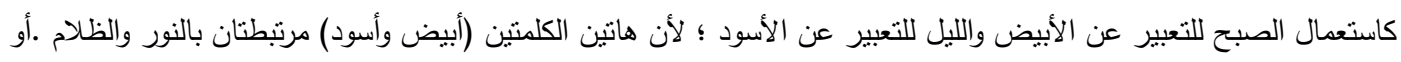

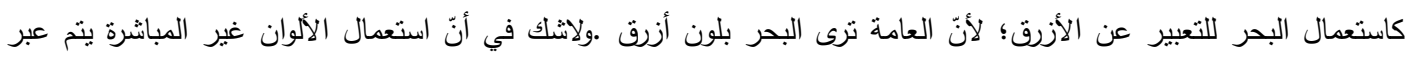

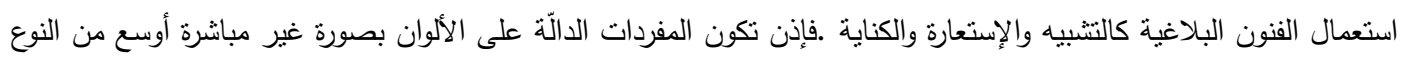

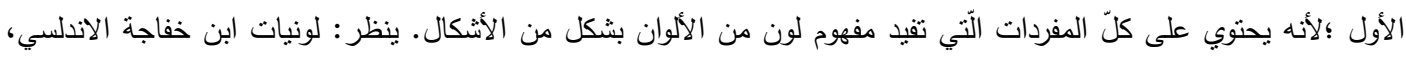

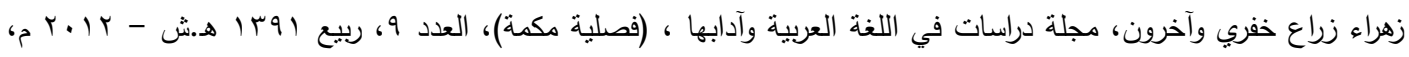

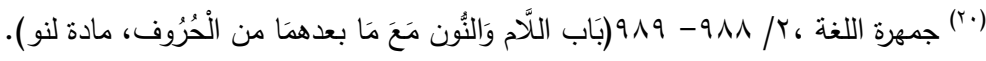

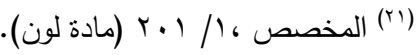

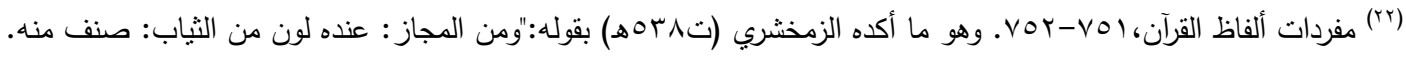

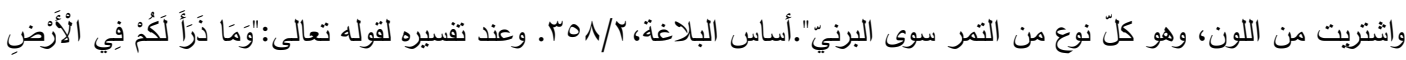

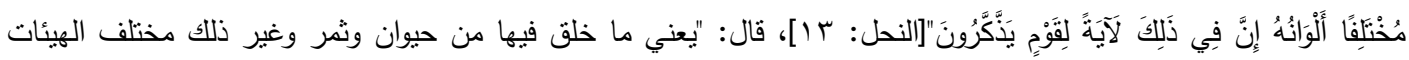

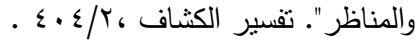

$$
\begin{aligned}
& \text { (r) }
\end{aligned}
$$

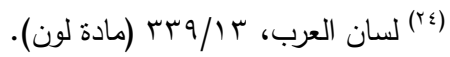




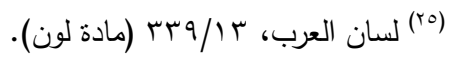

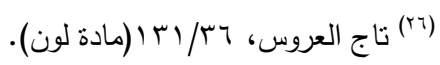

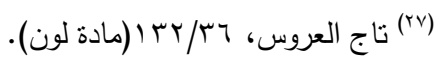

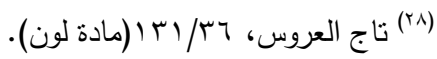

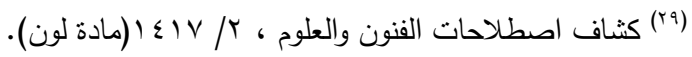

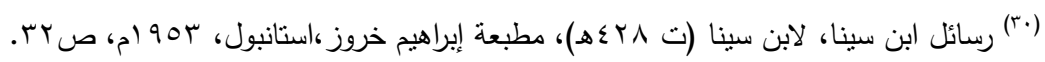

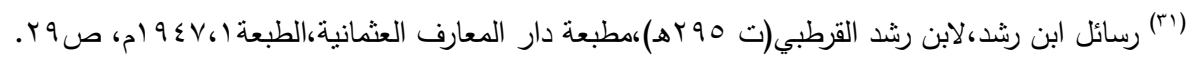

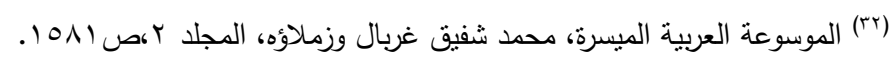

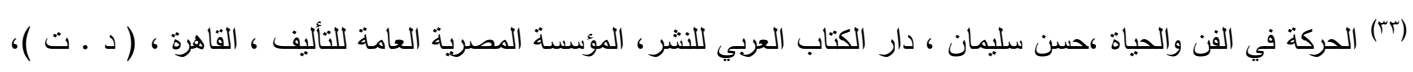

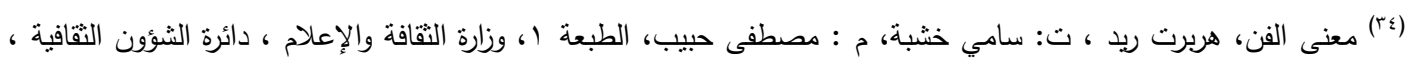

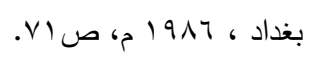

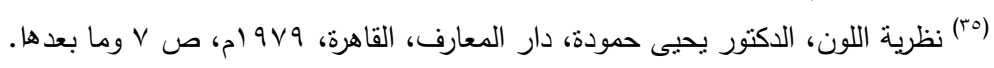

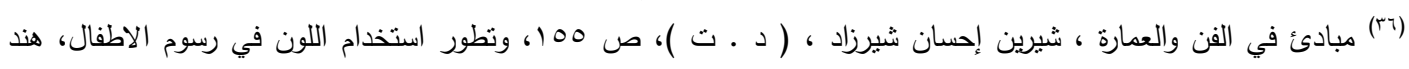

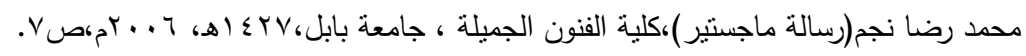

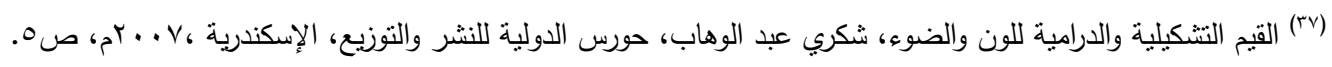

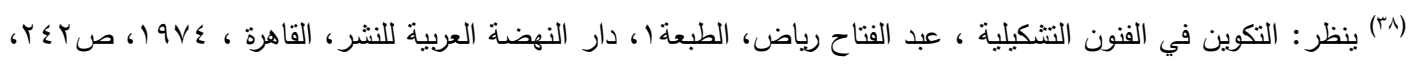
ونظرية اللون،ص V V وما بعدها.

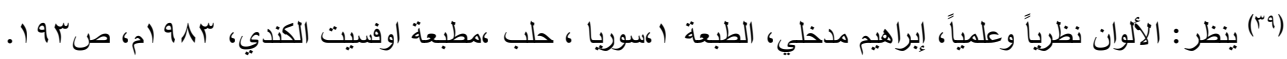

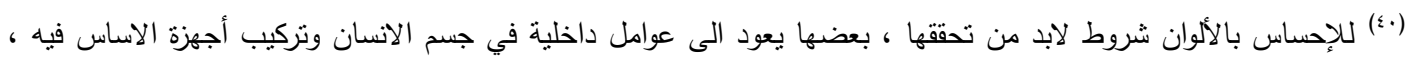

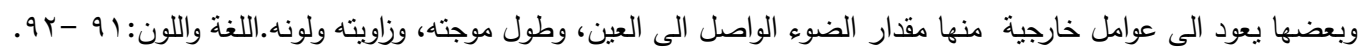

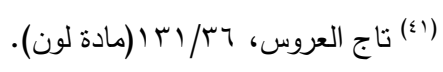

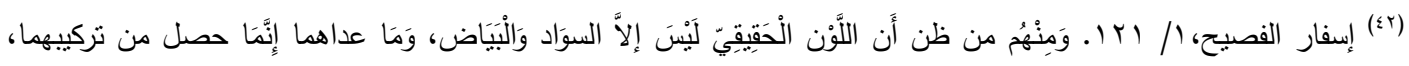

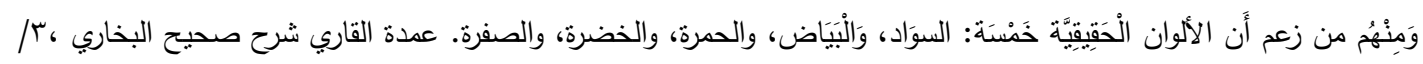

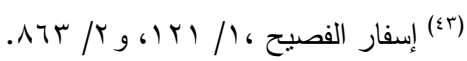

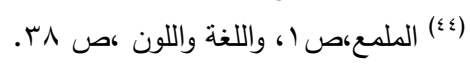

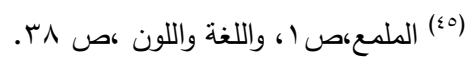

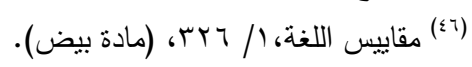

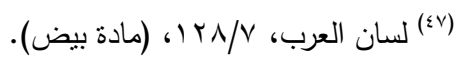




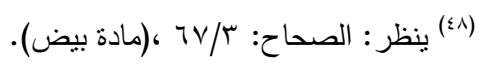

$$
\text { ين (19) }
$$

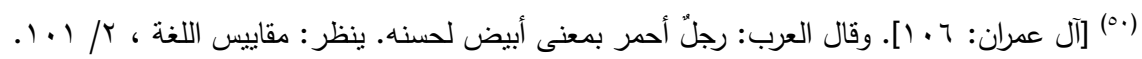

$$
\text { (10) }
$$

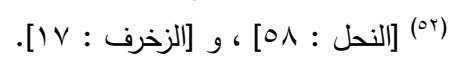

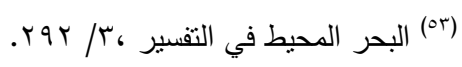

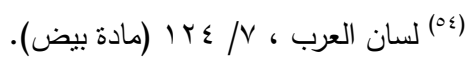

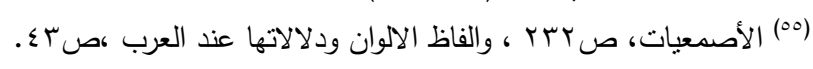

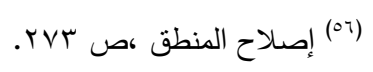

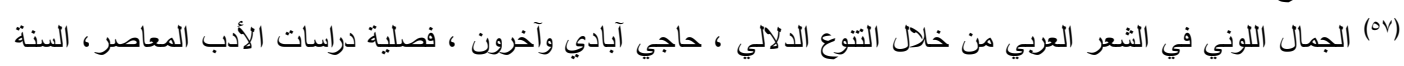

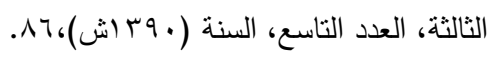

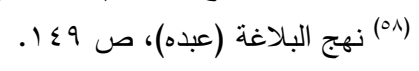

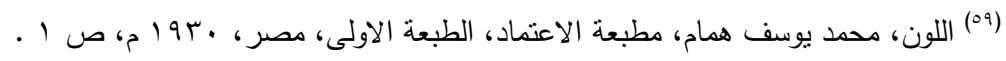

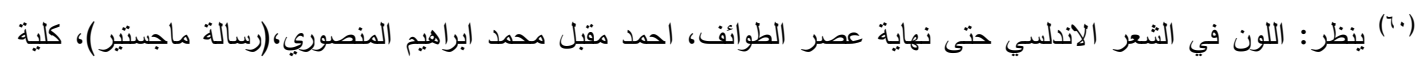

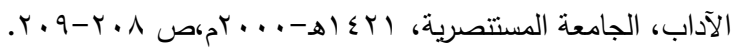

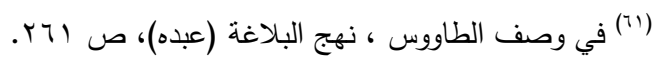

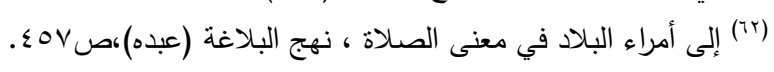

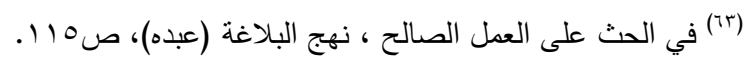

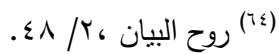

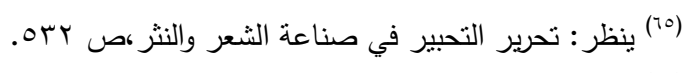

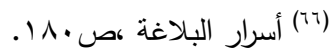

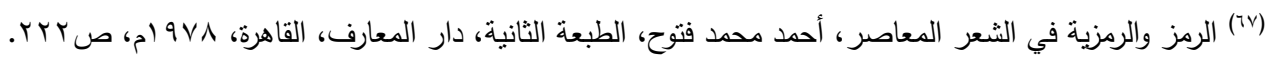

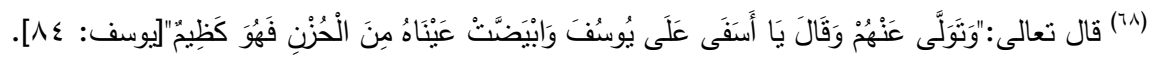

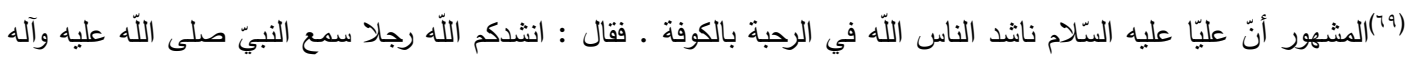

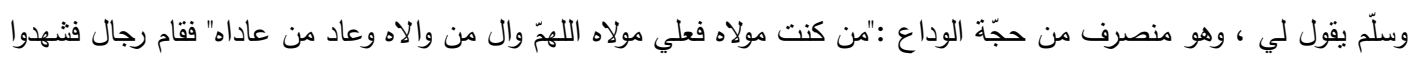

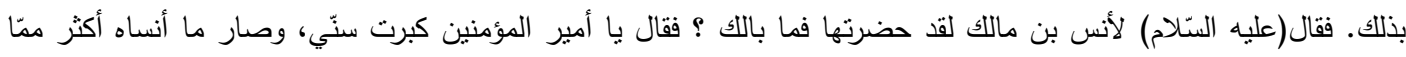

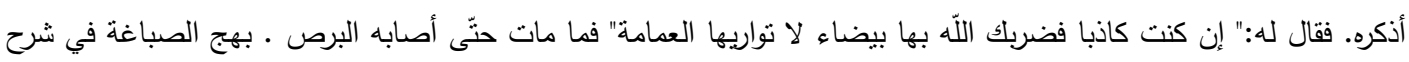

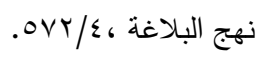




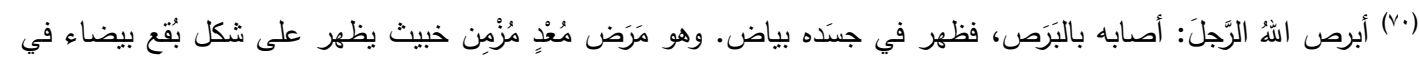

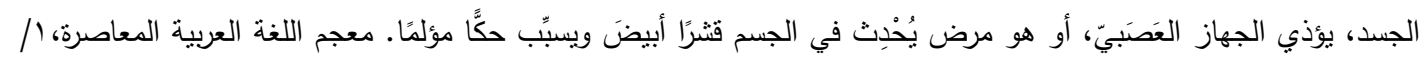
.19.

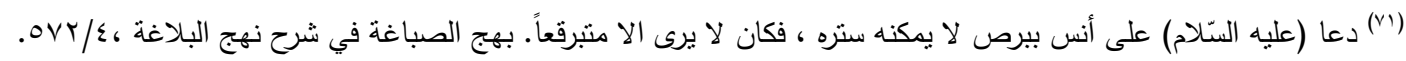

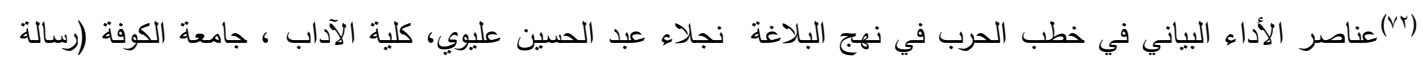

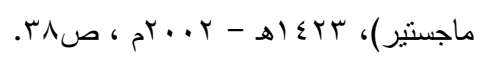

(Vr)

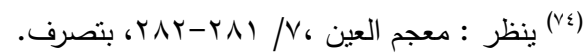

$$
\begin{aligned}
& \text {. ينظر : معجم العين (Vo) }
\end{aligned}
$$$$
\text { (V) }
$$

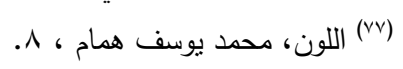

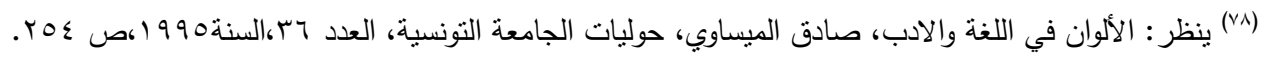

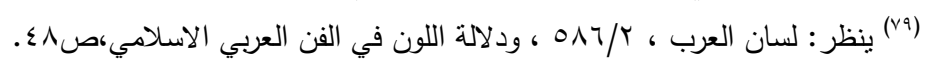

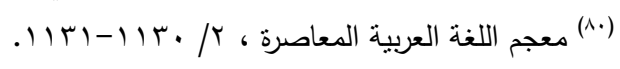

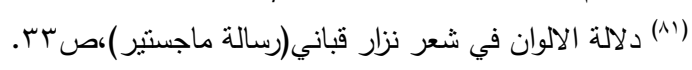

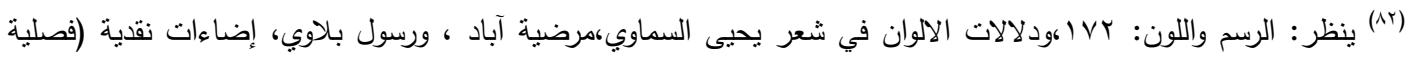

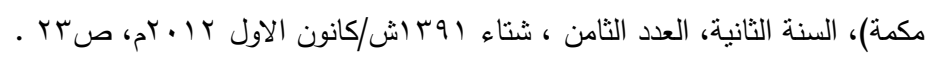

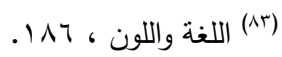

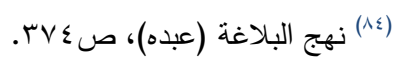

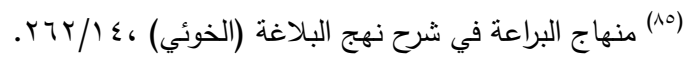

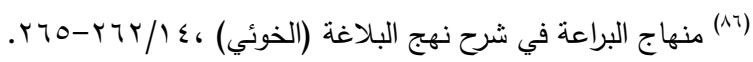

$$
\begin{aligned}
& \text { (Av) }
\end{aligned}
$$

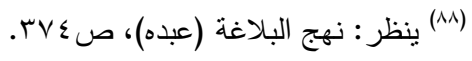

$$
\begin{aligned}
& \text { (A9) }
\end{aligned}
$$

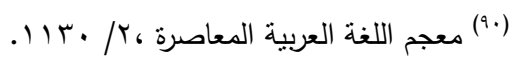

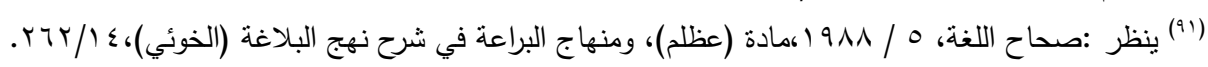

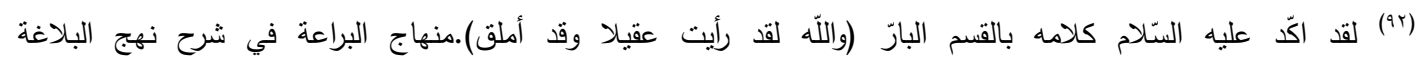

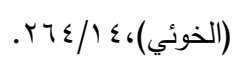

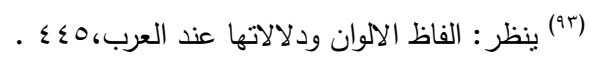

(9\&) ووصف الجوع بأنه أغبر ؛لأن الجائع برى الآفاق كأن عليها غبرة وظعلاماً. 


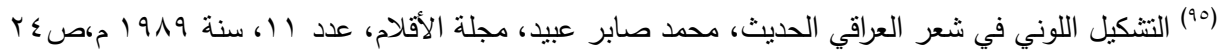

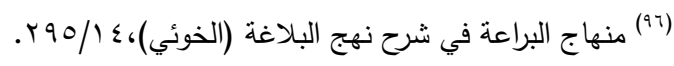

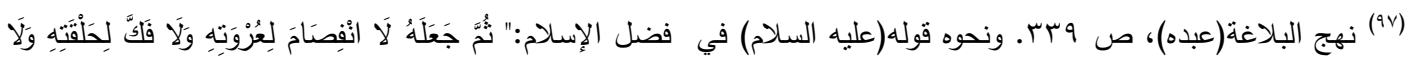

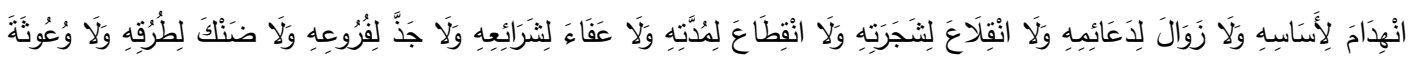

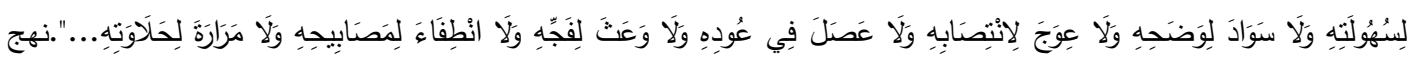

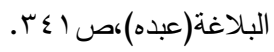

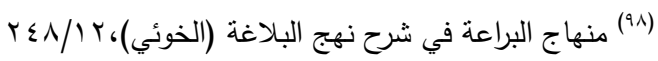

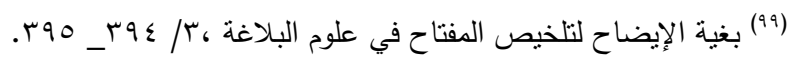

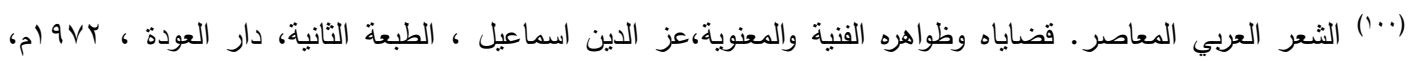

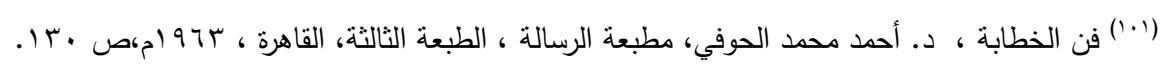

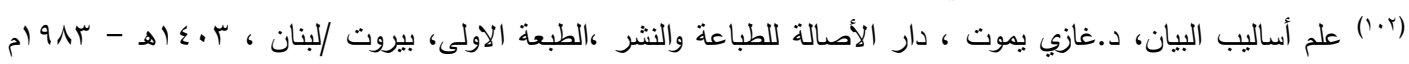

$$
\text { . } 17-\wedge 0 \text { ص }
$$

(r.1) الخطب الوعظية للإمام علي بن أبي طالب (كرم الله وجهه) - دراسة موضوعية فنية -،محد جواد علي البياتي، كلية

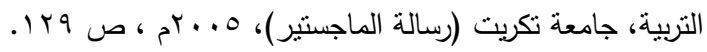

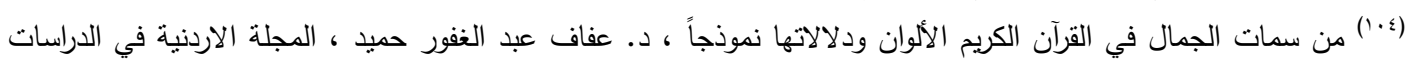

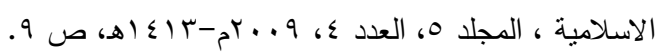

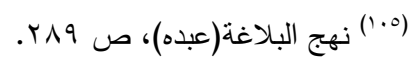

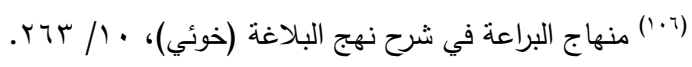

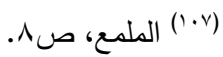

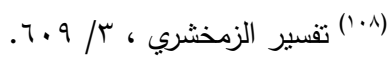

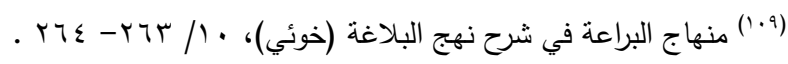

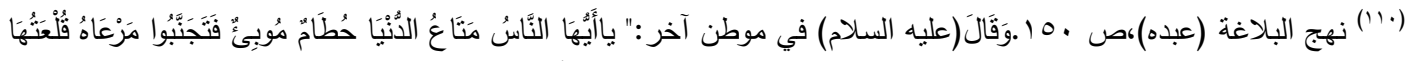

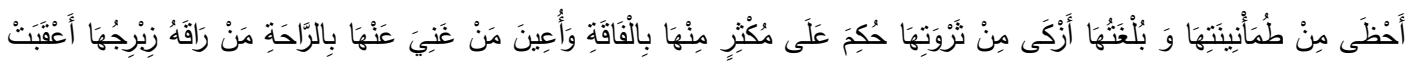

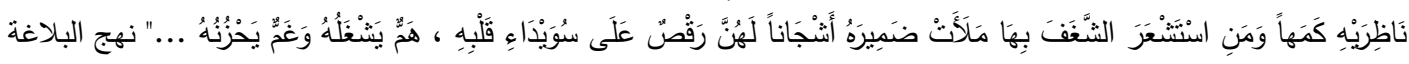

$$
\text { (عبده)، صar^) }
$$

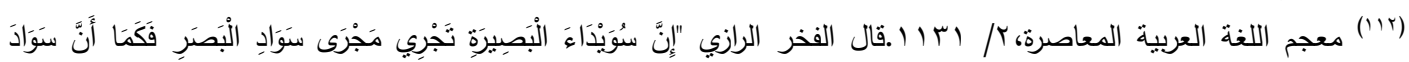

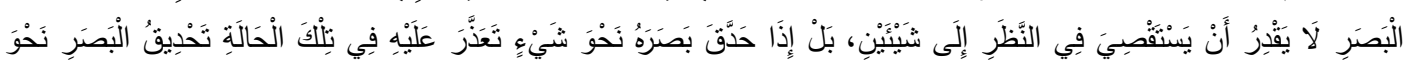




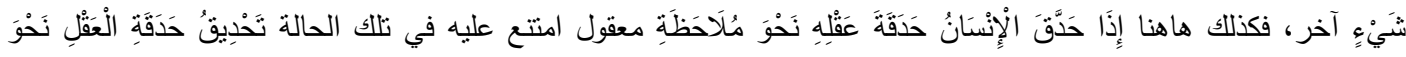

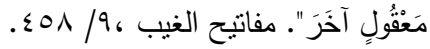

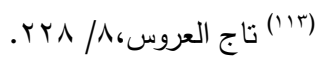

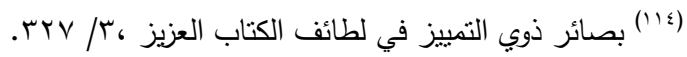

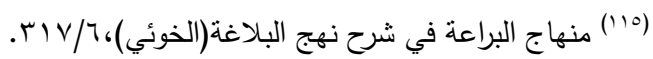

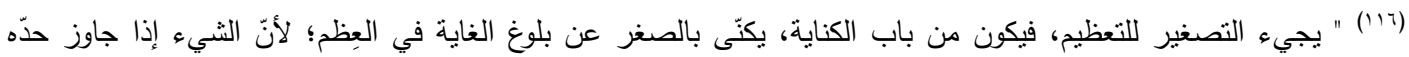

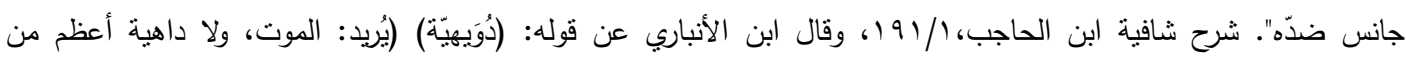

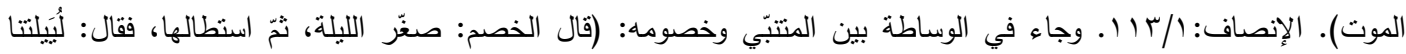

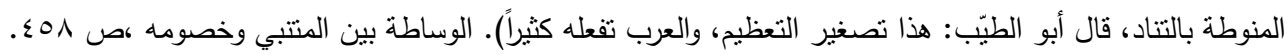

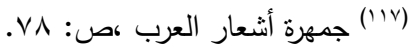

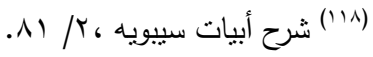

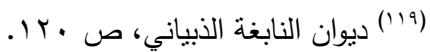

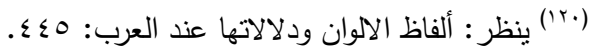

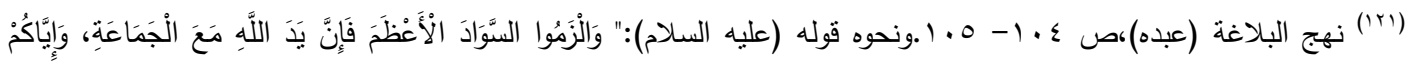

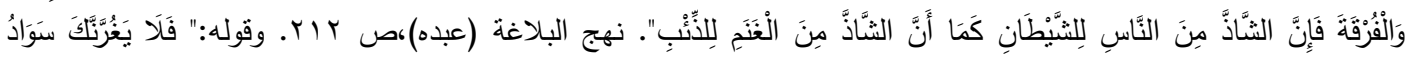

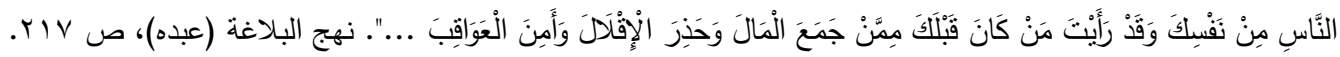

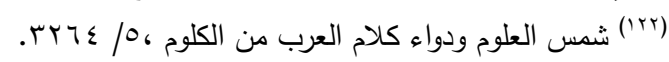

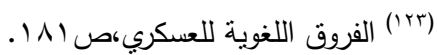

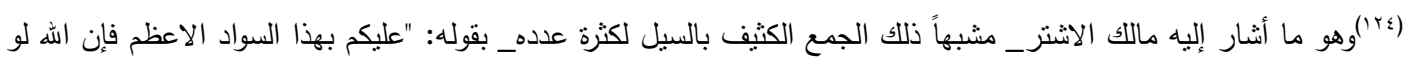

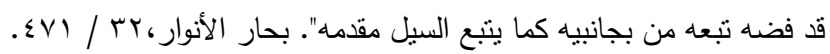

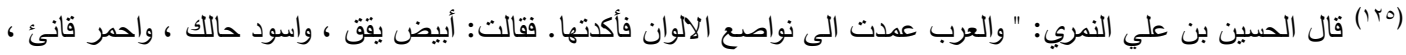

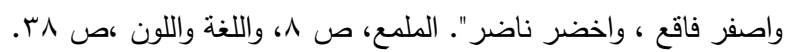

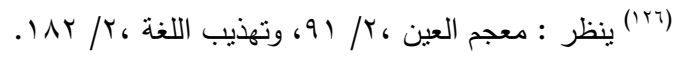
(Ir)

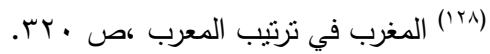

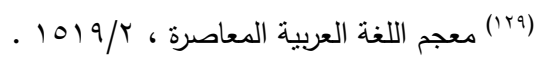

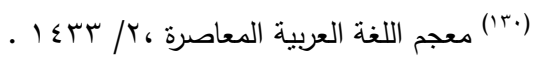

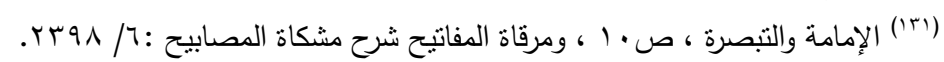

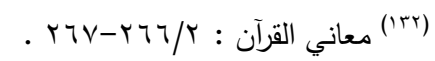

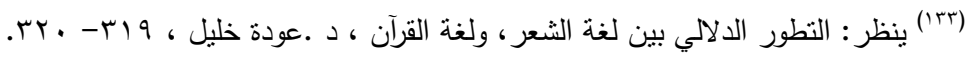




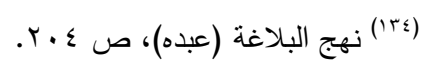

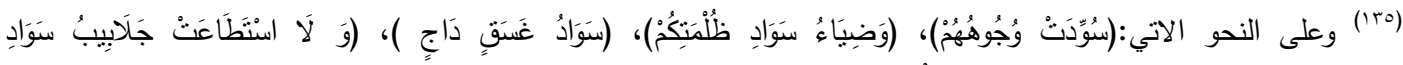

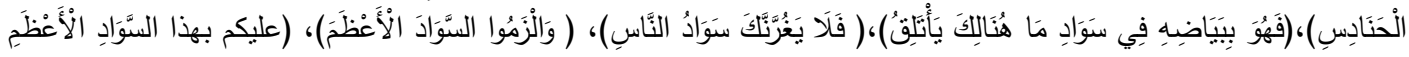

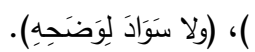

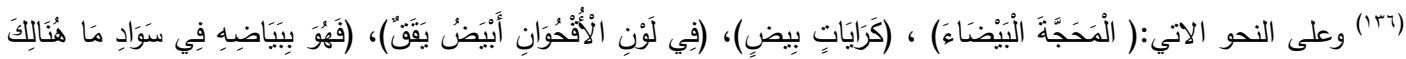

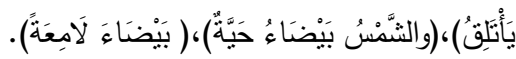

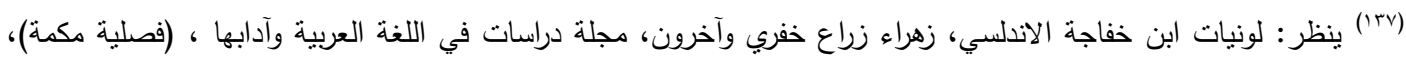

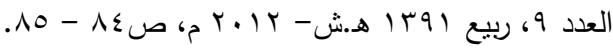

$$
\begin{aligned}
& \text { قائمة الدصادر والمراجع: }
\end{aligned}
$$

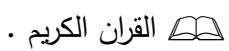

هو الأداء باللون في شعر زهير بن أبي سلمىهمحد عبد اله الجادي،مجلة كلية التربية،الجامعة المستتصرية ، العدد r، السنة

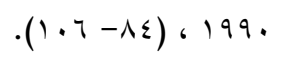

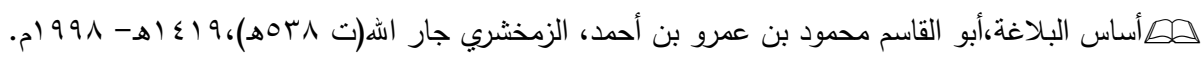

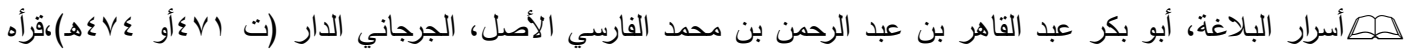

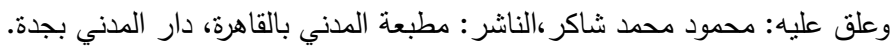

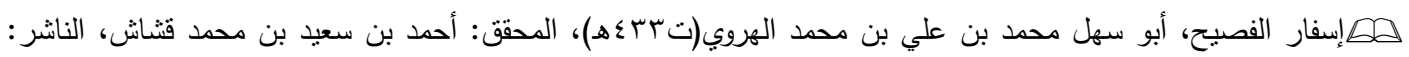

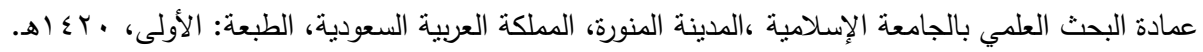

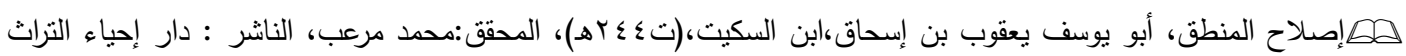

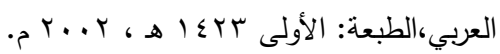

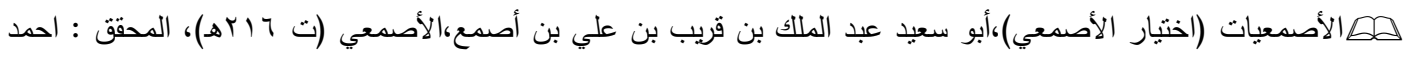

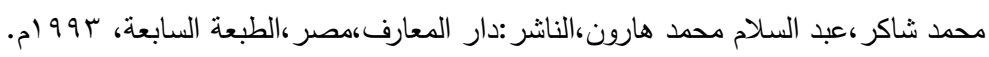

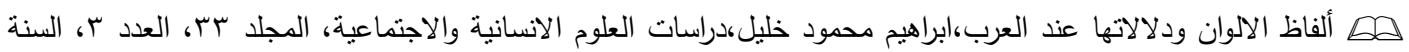

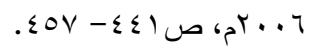

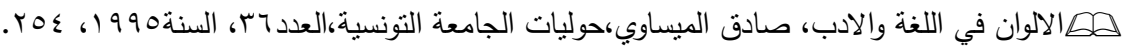

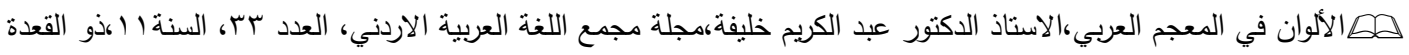

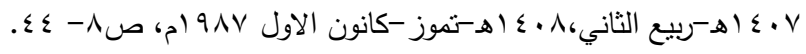

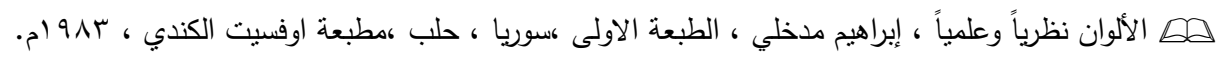

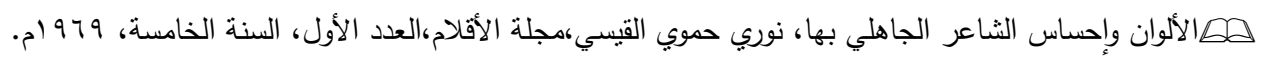

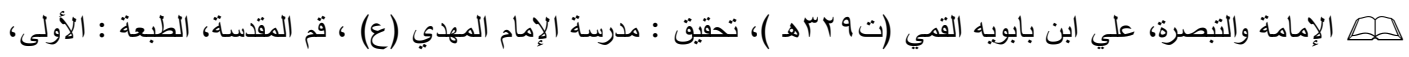

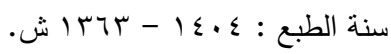




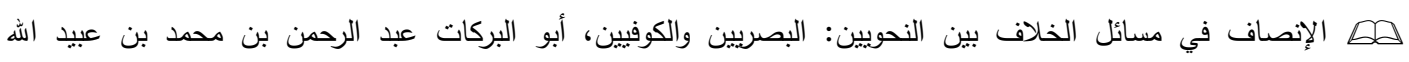

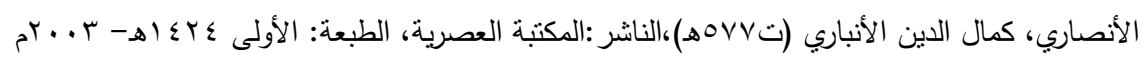

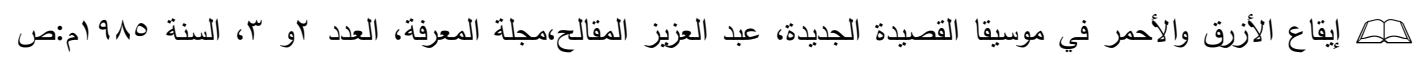
. $\curlyvee \wedge \varepsilon$ هم بحار الانوار الجامعة لدرر أخبار الائمة الاطهار : العلم العلامة الحجة فخر الامة المولى الثيخ محمد باقر المجلسيى ،

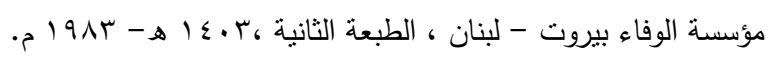

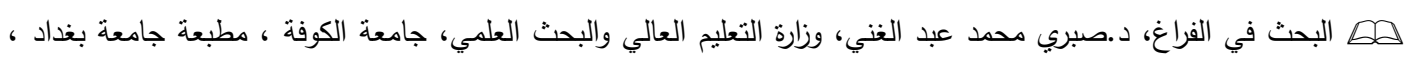
. 1919 هD البحر المحيط في التفسير، أبو حيان محمد بن يوسف بن علي بن يوسف بن حيان أثثر الدين الأندلسي

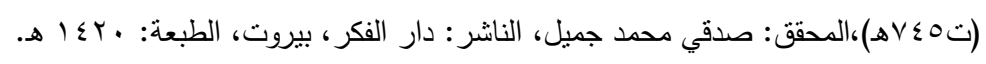

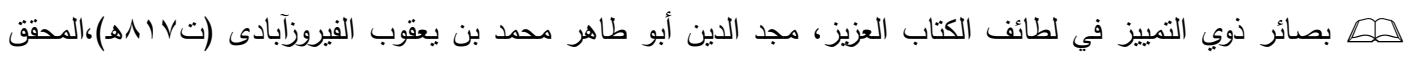

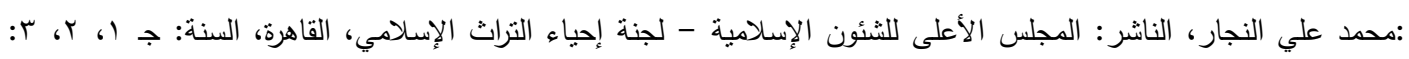

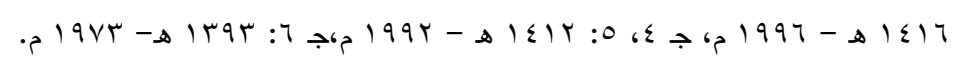

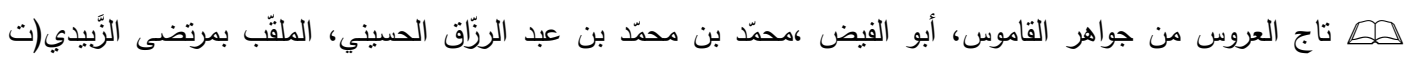

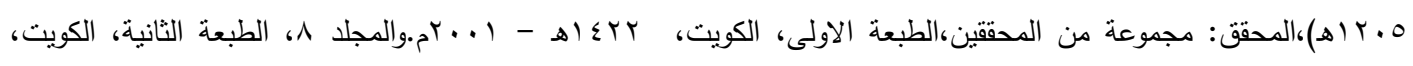

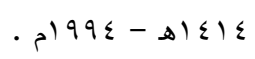

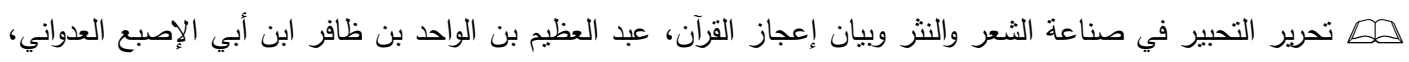

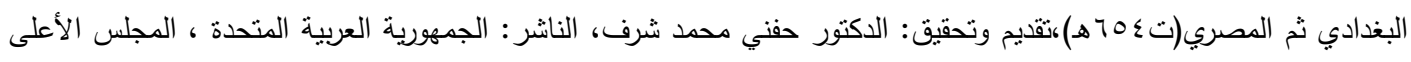

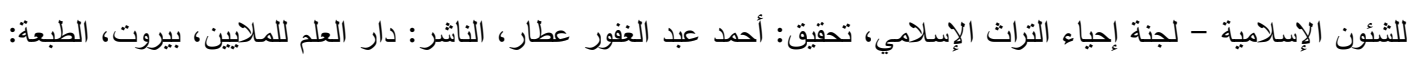

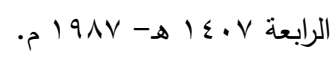
هم تداخل الفنون في شعر سعدي يوسف، د. إنشراق مظلوم زكي التميمي، ، دار الثُؤون العامة ، وزارة الثقافة ، العراق، بغداد ،

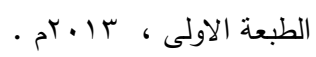

هD التشكيل اللوني في شعر العراقي الحديث، محمد صابر عبيد، مجلة الأقلام، عدد الإ، سنة 1919 م. م.

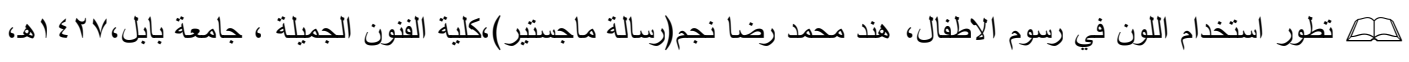
. هص التطور الدلالي بين لغة الثعر ، ولغة القرآن ، د .عودة خليل ، مكتبة المنار ، الاردن ، الزرقاء ، الطبعة الاولى ، هـ ـاهـ . $9190-$

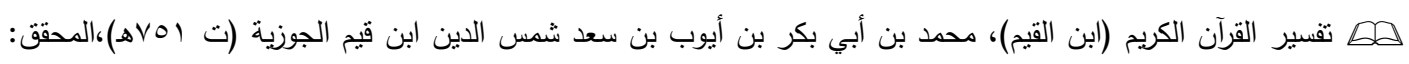

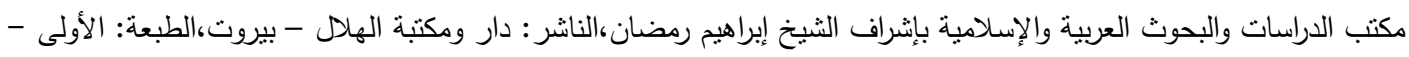


لهD التكوين في الفنون التثكيلية ، عبد الفتاح رياض، الطبعة الاولى، دار النهضة العربية للنشر، القاهرة ، ع 9 ام.

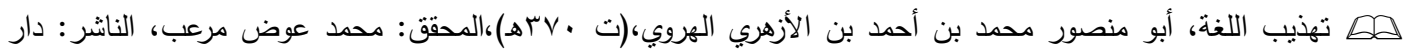

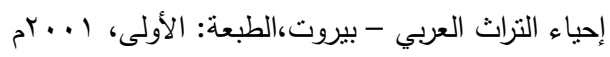
هD ثمار القلوب في المضاف والمنسوب، أبو منصور عبد الملك بن محمد بن إسماعيل الثعالبي (ت وبــهـ)،الناشر : دار المعارف - القاهرة.

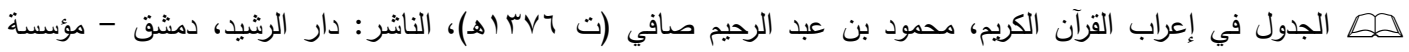

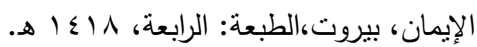

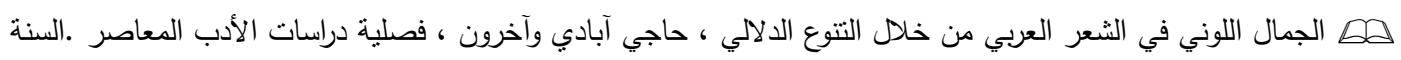

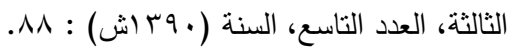

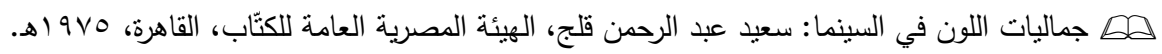

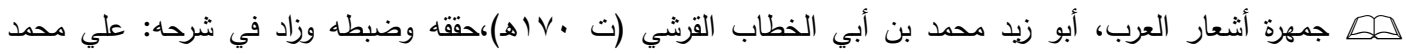

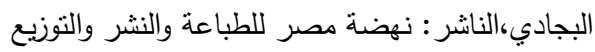
هم جمهرة اللغة،أبو بكر محمد بن الحسن بن دريد الأزدي(ت ابrاته)،المحقق: رمزي منير بعلبكي،الناشر : دار العلم للملايين -

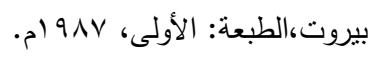
هD الحركة في الفن والحياة ،حسن سليمان ، دار الكتاب العربي للنشر، المؤسسة المصرية العامة للتأليف ، القاهرة ، ( د . ت هD الخطب الوعظية للإمام علي بن أبي طالب (كرم الله وجهة) - دراسة موضوعية فنية -،محمد جواد علي البياتي، كلية

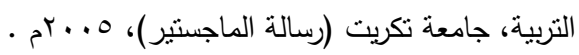
هـ دلالات الالوان في شعر يحيى السماوي، مرضية آباد، ورسول بلاوي، إضاءات نقدية (فصلية مكمة)، السنة الثانية، العدد

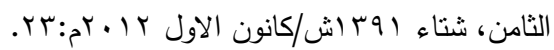

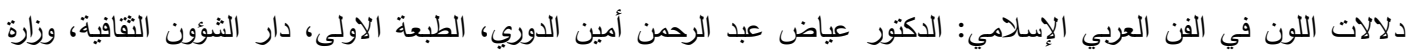

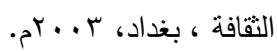
هم دلالة الالوان في شعر نزار قباني،أحمد عبد اله محمد حمدان ( رسالة ماجستير)، قسم اللغة العربية وآدابها بكلية الدراسات

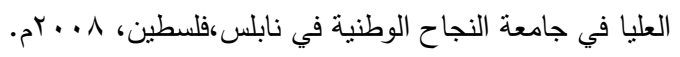

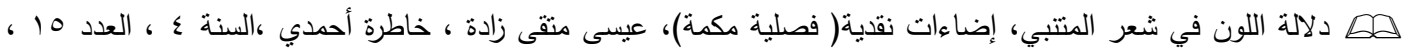

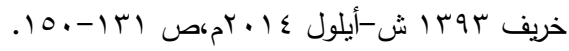
هم ديوان النابغة الذبياني، نقلا عن ديوان الثعراء الخمسة ببعض تصرف وتتقيح ، طبع بمطبعة الهلال بالفجالة بمصر ، سنة : . 1911 هD رسائل إبن رشد: أبو الوليد محمد بن احمد بن رشد القرطبي(ت 90 بهـ)- مطبعة دار المعارف العثمانية- حيدر أباد الدكن-

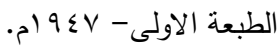




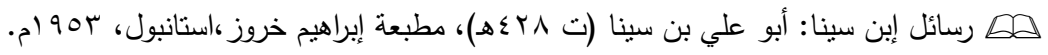

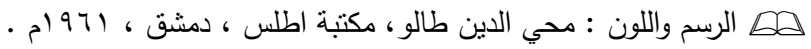

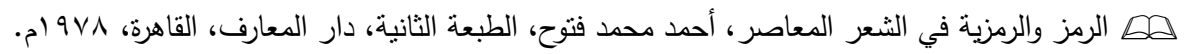

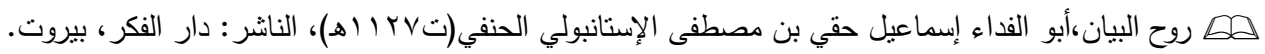

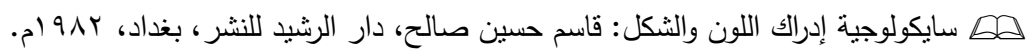

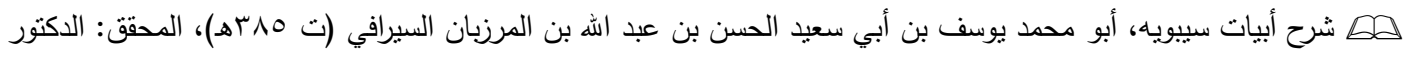

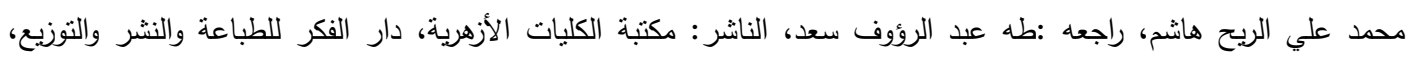

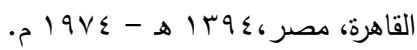

هD شرح شافية ابن الحاجب، محمد بن الحسن الرضي الإستراباذي،نجم الدين (ت T14هـ)، حققهما، وضبط غريبهما، وشرح

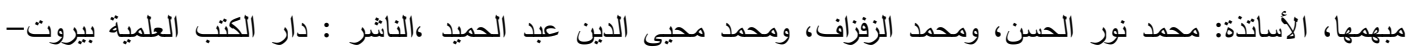

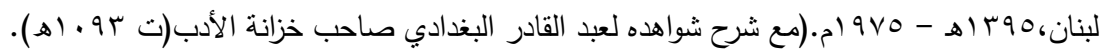

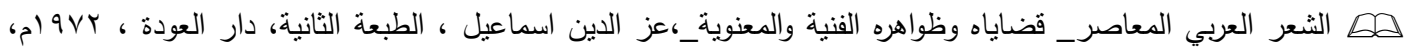
صוN.

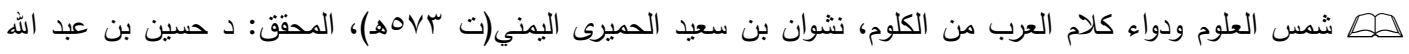

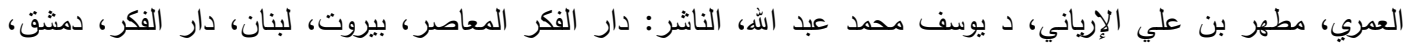

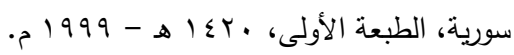
هD الصحاح تاج اللغة وصحاح العربية، أبو نصر إسماعيل بن حماد الجوهري الفارابي (ت بهوبه)، تحقيق: أحمد عبد الغفور

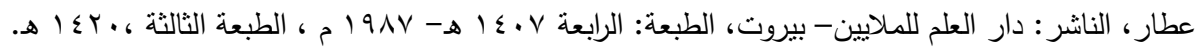

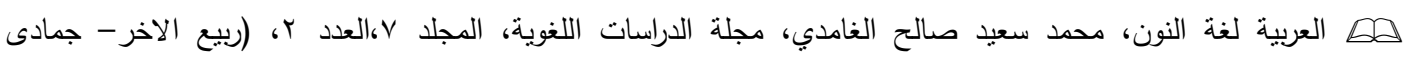

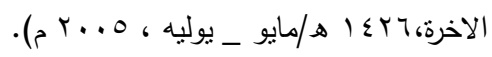

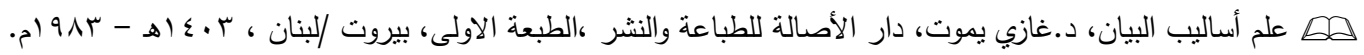

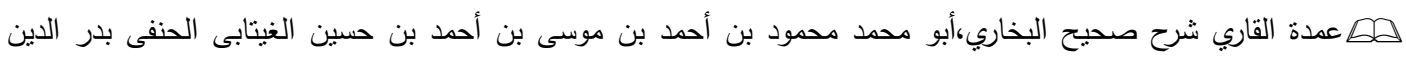

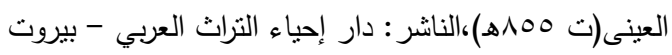
هD عناصر الأداء البياني في خطب الحرب في نهج البلاغة نجلاء عبد الحسين عليوي، كلية الآداب ، جامعة الكوفة (رسالة

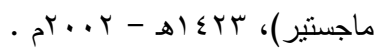

هD الفروق اللغوية، أبو هلال الحسن بن عبد الله بن سهل بن سعيد بن يحيى بن مهران العسكري (ت نحو 90بهـ)،حققه وعلق

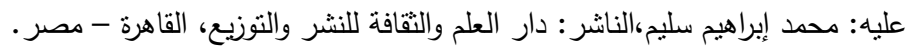

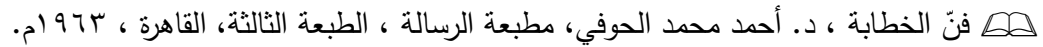

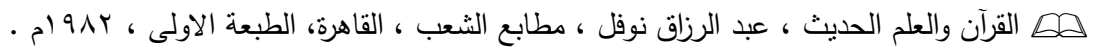

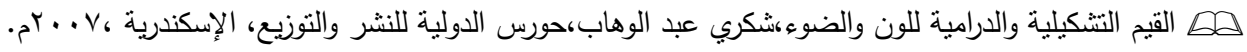


هDكثاف اصطلاحات الفنون والعلوم ، محمد علي الفارقي التهانوي (من رجال القرن الثاني عشر)، تحقيق الدكتور لطفي عبد

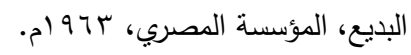
هD الكثاف عن حقائق غوامض التنزيل، أبو القاسم محمود بن عمرو بن أحمد، الزمخشري جار الله (ت ^بـهـ) ، الناشر :دار

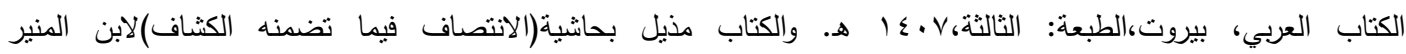

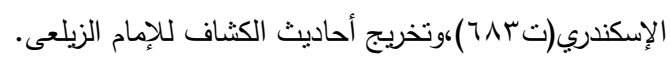

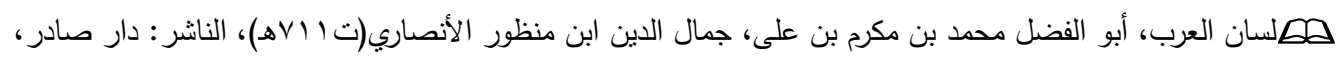

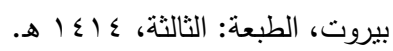

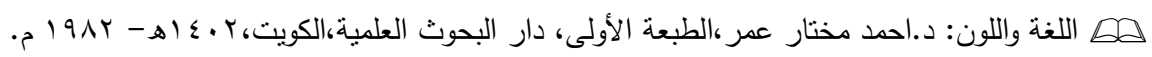

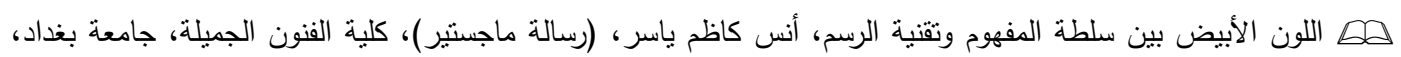
.r..r هم اللون في الثعر الاندلسي حتى نهاية عصر الطوائف، أحمد مقبل محمد ابراهيم المنصوري ، (رسالة ماجستير)، كلية

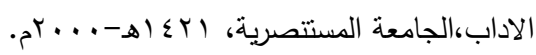

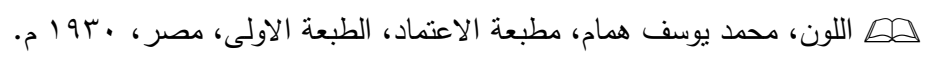

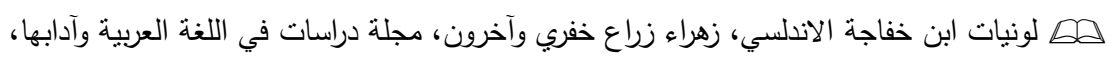

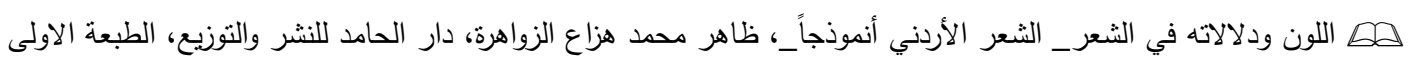
.... ، هD اللون ودلالاته في القران الكريم ،نجاح حسن محمد الربابعة (رسالة ماجسنير) في الادب، قسم اللغة العربية وآدابها ، عمادة

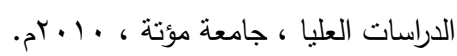

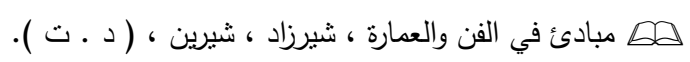

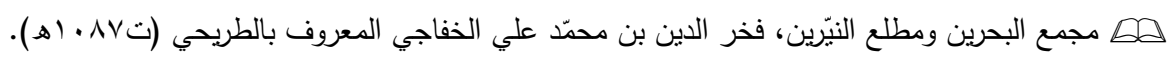

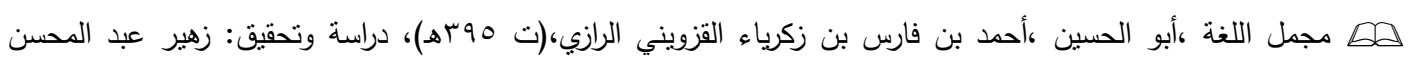

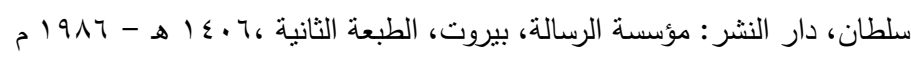

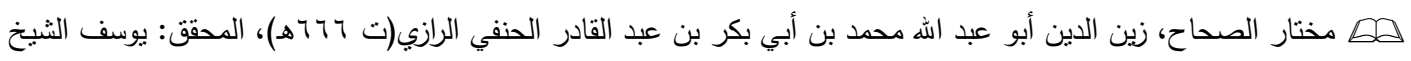

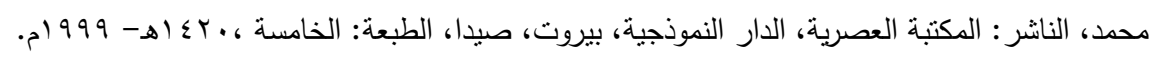

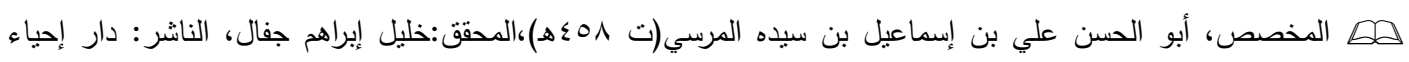

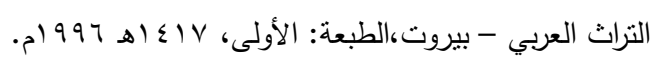

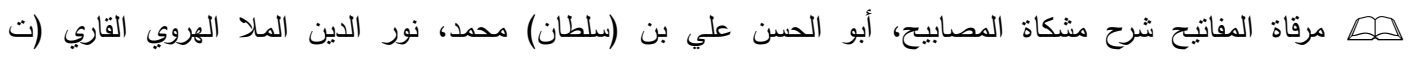

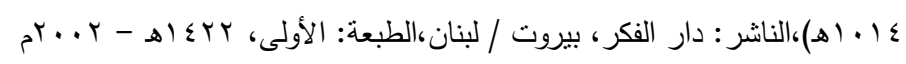

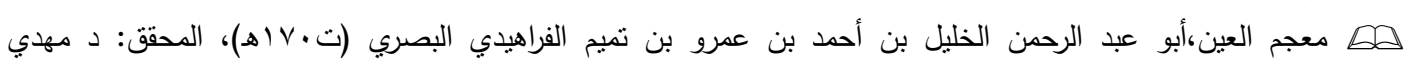

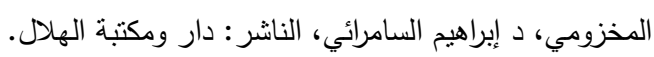




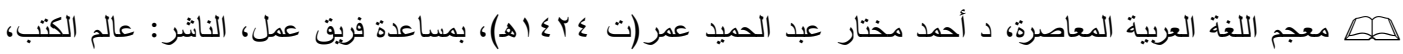

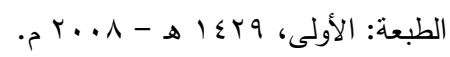

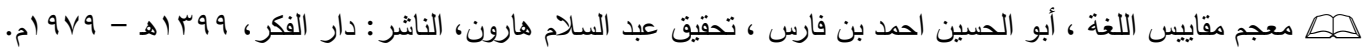
هD معنى الفن،هربرت ريد ، ت: سامي خشبة، م: مصطفى حبيب ، الطبعة الاولى ، وزارة الثقافة والإعلام ، دائرة الثُؤون الثقافية ، بغداد ، 1917 م م.

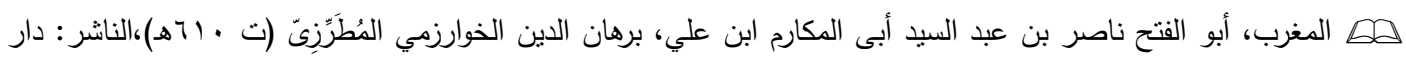

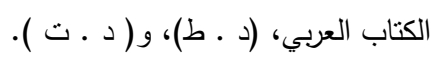
هم مفاتيح الغيب(التفسير الكبير)،أبو عبد الله محمد بن عمر بن الحسن بن الحسين التيمي الرازي الملقب بفخر الدين الرازي

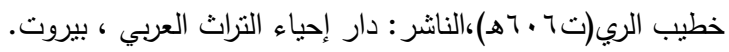

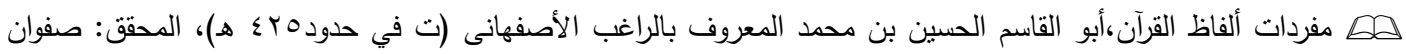

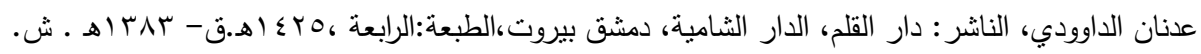

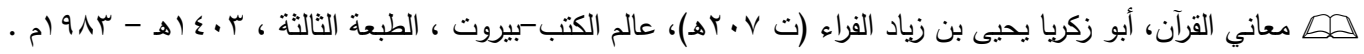

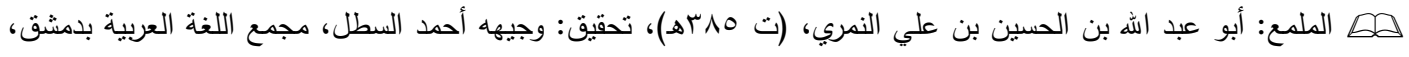

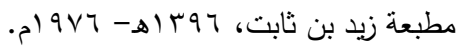

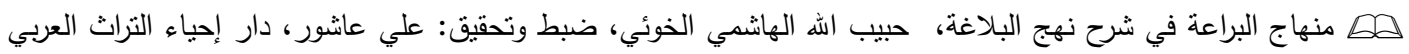

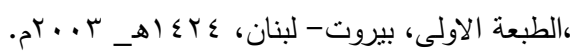
هD الموسوعة العربية الميسرة ،محمد شفيق غربال وزملاؤه، دار نهضة لبنان، بيروت، لبنان ، 9191 ام.

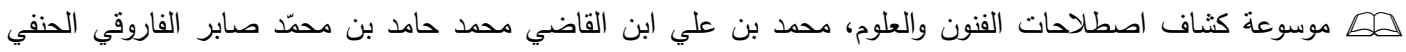

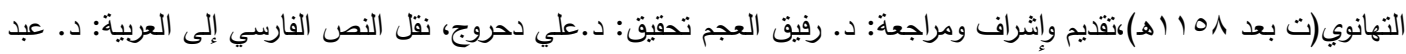

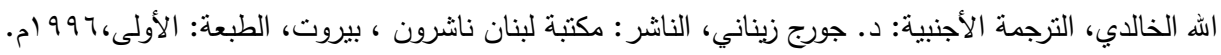

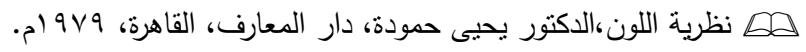

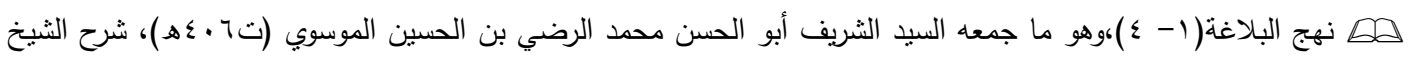

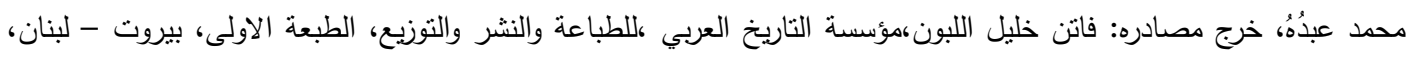
. هD نهج البلاغة،وهو ما جمعه السيد الثريف أبو الحسن محمد الرضي بن الحسين الموسوي (ت7 + ـهـ)، ضبط نصه وابتكر فهارسه العلمية د. صبحي الصالح،الطبعة السادسة، الناشر: دار الاسوة للطباعة والنشر (التابعة لمنظمة الاوقاف والثُؤون

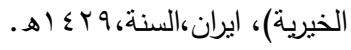

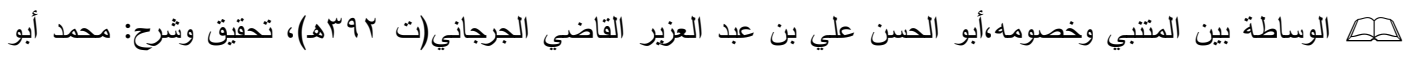

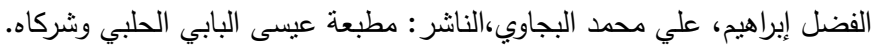

